Development of One-pot Asymmetric Azaelectrocyclization Protocol: Synthesis of 2,4-Disubstituted Chiral Piperidines

Toyoharu Kobayashi, Miyuki Nakashima, Toshikazu Hakogi, Katsunori Tanaka, and Shigeo Katsumura*

Department of Chemistry, School of Science and tecnhology, Kwansei Gakuin University, Gakuen, Sanda, 669-1337, Hyogo, Japan 
Experimental section

All commercially available reagents were used without further purification. All solvents were used after distillation. Diethylether, and benzene were refluxed over and distilled from sodium. Dichloromethane and acetonitrile were refluxed over and distilled from $\mathrm{P}_{2} \mathrm{O}_{5}$. Preparative separation was usually performed by column chromatography on silica gel (FUJI silysia LTD, BW-200 and BW-300) and on aluminum oxide (Merck, Aluminum oxide 90 , standardized, activity II-III) deactivated with 5 w $/ \%$ of $\mathrm{H}_{2} \mathrm{O} .1 \mathrm{H}$ NMR and 13C NMR spectra were recorded on either a JEOL $\alpha-400$ or a JNM-ECX $400 \mathrm{KA}$ spectrometer and chemical shifts were represented as $\delta$-values relative to the internal standard TMS. IR spectra were recorded on a JASCO FT/IR-8000 Fourier Transform Infrared Spectrometer. Optical rotations were measured with a JASCO DIP370 Digital Polarimeter. High resolution mass spectra (HRMS) were measured on either a JEOL JMS-T100LC or a JEOL JMS-700T spectrometer. Melting point was uncorrected.

One-pot reaction by using (-)-b, 1 and 4. To a solution of the vinyliodide 4 (100 $\mathrm{mg}$, $0.394 \mathrm{mmol})$ and molecular sieve $4 \AA(394 \mathrm{mg})$ in DMF $(4.0 \mathrm{~mL})$ was added (1S, 2R)(-)-cis-1-amino-2-indanol (-)-b $(71 \mathrm{mg}, 0.473 \mathrm{mmol})$ at room temperature, and the mixture was stirred for $30 \mathrm{~min}$ at this temperature. Then to this solution was added lithium chloride (33 mg, $0.788 \mathrm{mmol})$, Tri(2-furyl)phosphine $(7 \mathrm{mg}, 0.063 \mathrm{mmol})$ and Tris(dibenzylideneacetone)dipalladium $(0)(7 \mathrm{mg}, 0.008 \mathrm{mmol})$ at room temperature, and the mixture was stirred for $10 \mathrm{~min}$ at this temperature then vinylstannane 1 (310 $\mathrm{mg}$, $0.788 \mathrm{mmol}$ ) was added to this solution. After the reaction mixture was stirred at $80^{\circ} \mathrm{C}$ for $1 \mathrm{~h}, 10 \%$ aqueous $\mathrm{NH}_{3}$ solution was added, and the resulting mixture was extracted with ether. The organic layers were combined, washed with brine, dried over $\mathrm{MgSO}_{4}$, filtered and concentrated in vacuo to give the crude products. Column chromatography on silica gel (from $2 \%$ to $9 \%$ ethyl acetate in hexane) gave the 1,2,5,6tetrahydropyridine derivative (-)-1b $(117 \mathrm{mg}, 82 \%)$ as yellow oil: $($ Major/minor $=3: 1$ determined by ${ }^{1} \mathrm{H}$ NMR.) These stereoisomers could be separated by preparative TLC on silica gel twice (17\% ethyl acetate in hexane); $[\alpha]^{20}{ }_{\mathrm{D}}-63.8\left(\mathrm{c} 0.5, \mathrm{CHCl}_{3}\right)$; IR (neat, $\left.\mathrm{cm}^{-1}\right) 1715,1269,1244,1032$; $1 \mathrm{H}$ NMR $\left(400 \mathrm{MHz}, \mathrm{CDCl}_{3}\right) \delta 7.58(\mathrm{dm}, 2 \mathrm{H}, J=6.8 \mathrm{~Hz})$, $7.45(\mathrm{ddm}, 2 \mathrm{H}, J=7.3,7.3 \mathrm{~Hz}), 7.37-7.33(\mathrm{~m}, 1 \mathrm{H}), 7.23-7.13(\mathrm{~m}, 4 \mathrm{H}), 6.79(\mathrm{dd}, 1 \mathrm{H}, J=$ $4.1,2.0 \mathrm{~Hz}), 4.93(\mathrm{ddd}, 1 \mathrm{H}, J=5.9,5.9,1.5 \mathrm{~Hz}), 4.75(\mathrm{~d}, 1 \mathrm{H}, J=5.6 \mathrm{~Hz}), 4.50(\mathrm{dd}, 1 \mathrm{H}$, $J=3.2,3.2 \mathrm{~Hz}), 4.23(\mathrm{dd}, 1 \mathrm{H}, J=6.1,3.7 \mathrm{~Hz}), 4.16(\mathrm{qm}, 2 \mathrm{H}, J=7.3 \mathrm{~Hz}), 3.23(\mathrm{dd}, 1 \mathrm{H}$, $J=18.1,6.1 \mathrm{~Hz}), 3.15(\mathrm{~d}, 1 \mathrm{H}, J=17.8 \mathrm{~Hz}), 2.75-2.72(\mathrm{~m}, 2 \mathrm{H}), 1.24(\mathrm{t}, 3 \mathrm{H}, J=7.1 \mathrm{~Hz})$; 13C NMR (100 MHz, $\mathrm{CDCl}_{3}$ ) o 166.1, 142.9, 142.3, 140.0, 138.8 128.8, 128.4, 128.3, $127.8,125.5,124.4,124.1,86.7,75.4,74.9,61.2,60.6,39.5,25.6,14.2$; EI-HRMS m/e calcd for $\mathrm{C}_{23} \mathrm{H}_{23} \mathrm{NO}_{3}\left(\mathrm{M}^{+}\right) 361.1677$, found 361.1676. Data for the minor isomer: $[\alpha]^{20}$ $+129.3\left(\mathrm{c} 0.3, \mathrm{CHCl}_{3}\right)$; IR( $\mathrm{KBr}$ disk, $\left.\mathrm{cm}^{-1}\right) 1713,1250,1051,1038 ;{ }^{1} \mathrm{H} \mathrm{NMR}(400 \mathrm{MHz}$, $\left.\mathrm{CDCl}_{3}\right) \delta 7.60(\mathrm{~d}, 2 \mathrm{H}, J=7.1 \mathrm{~Hz}), 7.46(\mathrm{dd}, 2 \mathrm{H}, J=7.3,7.3 \mathrm{~Hz}), 7.17-7.13(\mathrm{~m}, 1 \mathrm{H})$, 
$7.09(\mathrm{~d}, 1 \mathrm{H}, J=7.3 \mathrm{~Hz}), 6.70(\mathrm{dd}, 1 \mathrm{H}, J=2.4,2.4 \mathrm{~Hz}), 5.11(\mathrm{ddd}, 1 \mathrm{H}, J=5.6,5.6,2.7$ $\mathrm{Hz}), 4.86(\mathrm{~d}, 1 \mathrm{H}, J=5.9 \mathrm{~Hz}), 4.75-4.73(\mathrm{~m}, 1 \mathrm{H}), 4.13(\mathrm{qm}, 2 \mathrm{H}, J=7.3 \mathrm{~Hz}), 4.12(\mathrm{dd}$, $1 \mathrm{H}, J=4.1,4.1 \mathrm{~Hz}), 3.24-3.13(\mathrm{~m}, 2 \mathrm{H}), 2.84(\mathrm{ddd}, 1 \mathrm{H}, J=16.3,3.2,3.3 \mathrm{~Hz}), 2.36$ (dddd, $1 \mathrm{H}, J=15.4,8.3,4.1,2.7 \mathrm{~Hz}), 1.22(\mathrm{l}, 3 \mathrm{H}, J=7.1 \mathrm{~Hz}) ;{ }^{13} \mathrm{C}$ NMR $(100 \mathrm{MHz}$, $\left.\mathrm{CDCl}_{3}\right) \delta 166.4,143.7,140.8,139.8,136.4,129.9,129.1,128.5,127.9,127.8,126.6$, $126.2,125.2,85.5,80.2,65.9,60.7,59.8,39.7,31.0,14.1$; EI HRMS m/e calcd for $\mathrm{C}_{23} \mathrm{H}_{23} \mathrm{NO}_{3}\left[\mathrm{M}^{+}\right] 361.1677$, found 361.1685 .

One-pot reaction by using (-)-a, 1 and 4. 'T'o a solution of the vinyliodide 4 (300 $\mathrm{mg}$, $1.18 \mathrm{mmol})$ and molecular sieve $4 \AA(1.18 \mathrm{~g})$ in DMF $(6 \mathrm{~mL})$ was added (1S, 2R)-(-)cis-1-amino-7-isopropylindan-2-ol (-)-a (226 $\mathrm{mg}, 1.18 \mathrm{mmol})$ at room temperature, and the mixture was stirred for $30 \mathrm{~min}$ at this temperature. Then to this solution was added lithium chloride (100 mg, $2.36 \mathrm{mmol}$ ), Tri(2-furyl)phosphine (22 $\mathrm{mg}, 0.094 \mathrm{mmol})$ and Tris(dibenzylideneacetone)dipalladium $(0)(22 \mathrm{mg}, 0.024 \mathrm{mmol})$ at room temperature, and the mixture was stirred for $10 \mathrm{~min}$ at this temperature then vinylstannane $1(929 \mathrm{mg}$, $2.36 \mathrm{mmol}$ ) was added to this solution. After the reaction mixture was stirred at $80^{\circ} \mathrm{C}$ for $1 \mathrm{~h}, 10 \%$ aqueous $\mathrm{NH}_{3}$ solution was added, and the resulting mixture was extracted with ether. The organic layers were combined, washed with brine, dried over $\mathrm{MgSO}_{4}$, filtered and concentrated in vacuo to give a $40: 1$ mixture of two stereoisomers crude products. These isomers were successfully scparated by column chromatography on silica gel (from $5 \%$ to $9 \%$ ethyl acetate in hexane) gave the 1,2,5,6-tetrahydropyridine derivative (-)-2a $(1.77 \mathrm{~g}, 84 \%)$ as white foam: $[\alpha]_{\mathrm{D}}^{19}-58.7\left(\mathrm{c} \mathrm{0.3}, \mathrm{CHCl}_{3}\right)$; IR (neat, $\mathrm{cm}$ 1) $1717,1267,1242,1032 ;{ }^{1} \mathrm{H} \mathrm{NMR}\left(400 \mathrm{MHz}, \mathrm{CDCl}_{3}\right) 87.43-7.33(\mathrm{~m}, 5 \mathrm{H}), 7.17$ (dd, $1 \mathrm{H}, J=7.6,7.6 \mathrm{~Hz}), 7.01(\mathrm{~d}, 1 \mathrm{H}, J=8.8 \mathrm{~Hz}), 6.99(\mathrm{~d}, 1 \mathrm{H}, J=8.1 \mathrm{~Hz}), 6.80$ (brs, $1 \mathrm{H})$, $5.01-4.96(\mathrm{~m}, 1 \mathrm{H}), 4.92(\mathrm{~d}, 1 \mathrm{H}, J=5.6 \mathrm{~Hz}), 4.48(\mathrm{~d}, 1 \mathrm{H}, J=4.4 \mathrm{~Hz}), 4.18(\mathrm{qm}, 2 \mathrm{H}, J=$ $7.3 \mathrm{~Hz}), 4.12(\mathrm{dd}, 1 \mathrm{H}, J=6.1,3.7 \mathrm{~Hz}), 3.15-3.25(\mathrm{~m}, 2 \mathrm{H}), 2.79(\mathrm{dm}, 1 \mathrm{H}, J=19.3 \mathrm{~Hz})$, 2.70 (dddd, $1 \mathrm{H}, J=19.3,6.6,2.2,2.2 \mathrm{~Hz}), 2.62(\mathrm{qq}, 1 \mathrm{H}, J=6.8,6.8 \mathrm{~Hz}), 1.25$ (t, 3H, $J$ $=7.1 \mathrm{~Hz}), 1.01(\mathrm{~d}, 3 \mathrm{H}, J=6.8 \mathrm{~Hz}), 0.59(\mathrm{~d}, 3 \mathrm{H}, J=7.1 \mathrm{~Hz}) ;{ }^{13} \mathrm{C}$ NMR $(100 \mathrm{MHz}$, $\left.\mathrm{CDCl}_{3}\right) \delta 166.3,147.8,143.1,141.5,138.3,136.3,129.4,128.8,128.4,128.0,124.0$, $123.5,121.6,86.7,75.0,74.4,62.2,60.6,39.6,28.0,25.5,23.5,22.8,14.2$; EI-HRMS m/e calcd for $\mathrm{C}_{26} \mathrm{H}_{29} \mathrm{NO}_{3}\left[\mathrm{M}^{+}\right]$403.2146, found 403.2137. Data for the minor isomer ; representative signals in its ${ }^{1} \mathrm{H} \mathrm{NMR}\left(400 \mathrm{MHz}, \mathrm{CDCl}_{3}\right) \delta \quad 6.60(\mathrm{brs}, 1 \mathrm{H}), 5.12(\mathrm{dd}, 1 \mathrm{H}$, $J=3.2,3.2 \mathrm{~Hz}), 4.85(\mathrm{~d}, 1 \mathrm{H}, J=6.0 \mathrm{~Hz})$.

One-pot reaction by using (-)-a, 4 and 5 . To a solution of the vinyliodide 4 (100 $\mathrm{mg}$, $0.394 \mathrm{mmol})$ and molecular sieve $4 \AA(394 \mathrm{mg})$ in DMF (2 mL) was added (1S, 2R)-(-)cis-1-amino-7-isopropylindan-2-ol (-)-a (90 $\mathrm{mg}, 0.473 \mathrm{mmol})$ at room temperature, and the mixture was stirred for $30 \mathrm{~min}$ at this temperature. Then to this solution was added lithium chloride (33 mg, $0.788 \mathrm{mmol})$, Tri(2-furyl)phosphine (7 $\mathrm{mg}, 0.03 \mathrm{mmol})$ and Tris(dibenzylideneacetone)dipalladium $(0)(7 \mathrm{mg}, 0.008 \mathrm{mmol})$ at room temperature, and the mixture was stirred for $10 \mathrm{~min}$ at this temperature then vinylstannane 5 (462 $\mathrm{mg}$, 
$0.788 \mathrm{mmol}$ ) was added to this solution. After the reaction mixture was stirred at $80^{\circ} \mathrm{C}$ for $1 \mathrm{~h}, 10 \%$ aqueous $\mathrm{NH}_{3}$ solution was added, and the resulting mixture was extracted with ether. The organic layers were combined, washed with brine, dried over $\mathrm{MgSO}_{4}$, filtered and concentrated in vacuo to give a $16: 1$ mixture of two stereoisomers crude products. These isomers were successfully separated by column chromatography on silica gel (from 5\% to $25 \%$ ethyl acetate in hexane) gave the 1,2,5,6-tetrahydropyridine derivative (-)-5a $(0.169 \mathrm{~g}, 72 \%)$ as yellow foam: $[\alpha]_{\nu}^{16}-87.0\left(c 0.7, \mathrm{CHCl}_{3}\right)$; IR $(\mathrm{KBr}$ disk, $\left.\mathrm{cm}^{-1}\right) 1715,1447,1373,1260,1175,1113,1030 ;{ }^{1} \mathrm{H}$ NMR $\left(400 \mathrm{MHz}, \mathrm{CDCl}_{3}\right) \delta$ $8.02(\mathrm{~d}, 1 \mathrm{H}, J=8.5 \mathrm{~Hz}), 7.84(\mathrm{ddd}, 2 \mathrm{H}, J=8.8,2.0,2.0 \mathrm{~Hz}), 7.66(\mathrm{~s}, 1 \mathrm{H}), 7.55(\mathrm{~d}, 1 \mathrm{H}, J$ $=7.8 \mathrm{~Hz}), 7.35(\mathrm{ddm}, 1 \mathrm{H}, J=7.3,7.3 \mathrm{~Hz}), 7.28-7.18(\mathrm{~m}, 3 \mathrm{H}), 7.13(\mathrm{dd}, 1 \mathrm{H}, J=7.6,7.6$ $\mathrm{Hz}), 6.98(\mathrm{~d}, 1 \mathrm{H}, J=7.6 \mathrm{~Hz}), 6.89(\mathrm{~d}, 1 \mathrm{H}, J=7.6 \mathrm{~Hz}), 6.80(\mathrm{dd}, 1 \mathrm{H}, J=3.7,2.0 \mathrm{~Hz})$, $5.00-4.94(\mathrm{~m}, 2 \mathrm{H}), 4.52(\mathrm{dd}, 1 \mathrm{H}, J=4.6,1.2 \mathrm{~Hz}), 4.34(\mathrm{dd}, 1 \mathrm{H}, J=6.3,3.9 \mathrm{~Hz}), 4.17$ (qm, 2H, $J=7.1 \mathrm{~Hz}), 3.23(\mathrm{dd}, 1 \mathrm{H}, J=18.1,5.9 \mathrm{~Hz}), 3.17$ (d, 1H, $J=17.1 \mathrm{~Hz}), 2.84$ $(\mathrm{dm}, 1 \mathrm{H}, J=19.5 \mathrm{~Hz}), 2.77$ (dddd, $1 \mathrm{H}, J=19.5,4.4,4.4,2,0 \mathrm{~Hz}), 2.52$ (qq, $1 \mathrm{H}, J=6.8$, $6.8 \mathrm{~Hz}), 2.32(\mathrm{~s}, 3 \mathrm{H}), 1.24(\mathrm{t}, 3 \mathrm{H}, J=7.1 \mathrm{~Hz}), 0.52(\mathrm{~d}, 3 \mathrm{H}, 6.6 \mathrm{~Hz}), 0.05(\mathrm{~d}, 3 \mathrm{H}, J=7.1$ $\mathrm{Hz}):{ }^{13} \mathrm{C}$ NMR $\left(100 \mathrm{MHz}, \mathrm{CDCl}_{3}\right) \delta 166.0,147.6,145.1,143.1,137.4,136.0,135.6$, $135.2,130.0,129.5,128.8,126.9,125.0,124.4,123.3,121.8,121.6,113.4,86.6,74.9$, $74.3,60.7,54.4,39.5,27.6,25.6,22.5,22.2,21.5$; EI HRMS m/e calcd. For $\mathrm{C}_{35} \mathrm{H}_{36} \mathrm{~N}_{2} \mathrm{O}_{5} \mathrm{~S}\left[\mathrm{M}^{+}\right]$596.2343, found 596.2345 : representative signals in its ${ }^{1} \mathrm{H}$ NMR (400 $\left.\mathrm{MHz}, \mathrm{CDCl}_{3}\right) \delta 6.68(\mathrm{brs}, 1 \mathrm{H}), 0.93(\mathrm{~d}, 1 \mathrm{H}, J=6.9 \mathrm{~Hz})$.

One-pot reaction by using (-)-a, 4 and 6. To a solution of the vinyliodide 4 (100 $\mathrm{mg}$, $0.394 \mathrm{mmol})$ and molecular sieve $4 \AA(394 \mathrm{mg})$ in DMF (2 mL) was added (1S, 2R)-(-)cis-1-amino-7-isopropylindan-2-ol (-)-a (90 $\mathrm{mg}, 0.473 \mathrm{mmol})$ at room temperature, and the mixture was stirred for $30 \mathrm{~min}$ at this temperature. Then to this solution was added lithium chloride (33 mg, $0.788 \mathrm{mmol})$, Tri(2-furyl)phosphine $(7 \mathrm{mg}, 0.03 \mathrm{mmol}$ ) and Tris(dibenzylideneacetone)dipalladium $(0)(7 \mathrm{mg}, 0.008 \mathrm{mmol})$ at room temperature, and the mixture was stirred for $10 \mathrm{~min}$ at this temperature then vinylstannane 6 (451 $\mathrm{mg}$, $0.788 \mathrm{mmol}$ ) was added to this solution. After the reaction mixture was stirred at $80^{\circ} \mathrm{C}$ for $1 \mathrm{~h}, 10 \%$ aqueous $\mathrm{NH}_{3}$ solution was added, and the resulting mixture was extracted with ether. The organic layers were combined, washed with brine, dried over $\mathrm{MgSO}_{4}$, filtered and concentrated in vacuo to give a 12:1 mixture of two stereoisomers crude products. These isomers were not separated by column chromatography on silica gel gave the 1,2,5,6-tetrahydropyridine derivative (-)-6a and isomer $(0.154 \mathrm{~g}, 67 \%)$ as yellow foam: Data for the major isomer (-)-6a : $[\mathrm{a}]_{\mathrm{D}}^{26}-37.5$ (c 0.1, CHCl3); IR (KBr disk $\left.\mathrm{cm}^{-1}\right) 1716,1448,1371,1255,1172,1030 ;{ }^{1} \mathrm{H} \mathrm{NMR}\left(400 \mathrm{MHz}, \mathrm{CDCl}_{3}\right) \delta 8.34(1 \mathrm{H}, \mathrm{d}, J$ $=8.5), 7.73(\mathrm{dd}, 2 \mathrm{H}, J=8.7,1.4), 7.52(\mathrm{ddm}, 1 \mathrm{H}, J=9.4,1.6), 7.43-7.36(\mathrm{~m}, 3 \mathrm{H}), 7.31$ (dd, $1 \mathrm{H}, J=7.3,7.3 \mathrm{~Hz}), 7.17(\mathrm{dd}, 1 \mathrm{H}, J=7.6,7.6 \mathrm{~Hz}), 6.99(\mathrm{~d}, 2 \mathrm{H}, J=6.6), 6.89(\mathrm{~s}$, $1 \mathrm{H}), 6.57(\mathrm{dm}, 1 \mathrm{H}, J=0.9 \mathrm{~Hz}), 5.23(\mathrm{dd}, 1 \mathrm{H}, J=6.0,3.0 \mathrm{~Hz}), 4.94(\mathrm{ddm}, 1 \mathrm{H}, J=8.9$, $3.7 \mathrm{~Hz}), 4.87(\mathrm{~d}, 1 \mathrm{H}, J=5.5 \mathrm{~Hz}), 4.47(\mathrm{~d}, 1 \mathrm{H}, J=4.6 \mathrm{~Hz}), 4.14(\mathrm{qm}, 2 \mathrm{H}, J=7.1 \mathrm{~Hz})$, $3.17(\mathrm{dm}, 1 \mathrm{H}, J=3.4 \mathrm{~Hz}), 2.91(\mathrm{qq}, 1 \mathrm{H}, J=6.9,6.9 \mathrm{~Hz}), 2.77(\mathrm{ddm}, 1 \mathrm{H}, J=19.2,2.5$ 
Hz), 2.60 (dddd, $1 \mathrm{H}, J=19.0,11.0,3.9,2.5 \mathrm{~Hz}), 1.25(\mathrm{tm}, 3 \mathrm{H}, J=7.1 \mathrm{~Hz}), 1.02(\mathrm{~d}, 3 \mathrm{H}$, $J=6.9 \mathrm{~Hz}), 0.54(\mathrm{~d}, 3 \mathrm{H}, J=7.1 \mathrm{~Hz}):{ }^{13} \mathrm{C} \mathrm{NMR}\left(100 \mathrm{MHz}, \mathrm{CDCl}_{3}\right) \delta 166.1,147.6$, $143.3,141.6,139.1,137.7,136.2,136.1,134.1,129.4,128.9,126.1,125.1,124.2,124.1$, $123.5,121.8,120.7,115.5,114.0,86.7,75.6,75.5,60.7,53.9,39.4,28.1,25.3,23.5$, 23.0, 14.2; ESI HRMS m/z calcd for $\mathrm{C}_{34} \mathrm{H}_{34} \mathrm{~N}_{2} \mathrm{O}_{5} \mathrm{~S}$ [M+ $\left.\mathrm{M}^{+}+\mathrm{Na}\right]$ 605.2086, found 605.2077; representative signals in its ${ }^{1} \mathrm{H}$ NMR $\left(400 \mathrm{MHz}, \mathrm{CDCl}_{3}\right) \delta 8.26(\mathrm{dd}, 1 \mathrm{H}, J=8.5,0.69$ $\mathrm{Hz}), 8.20(\mathrm{~d}, 1 \mathrm{H}, J=8.5 \mathrm{~Hz}), 8.14(\mathrm{~d}, 1 \mathrm{H}, J=8.5 \mathrm{~Hz}), 6.12(\mathrm{brs}, 1 \mathrm{H})$.

One-pot reaction by using (-)-a, 4 and 7. 'To a solution of the vinyliodide 4 (70 $\mathrm{mg}$, $0.276 \mathrm{mmol})$ and molecular sieve $4 \AA(276 \mathrm{mg})$ in DMF $(2.8 \mathrm{~mL})$ was added $(1 \mathrm{~S}, 2 \mathrm{R})$ (-)-cis-1-amino-7-isopropylindan-2-ol (-)-a $(63 \mathrm{mg}, 0.331 \mathrm{mmol})$ at room temperature, and the mixture was stirred for $30 \mathrm{~min}$ at this temperature. Then to this solution was added lithium chloride ( $23 \mathrm{mg}, 0.552 \mathrm{mmol}$ ), Tri(2-furyl)phosphine ( $5 \mathrm{mg}, 0.022 \mathrm{mmol}$ ) and Tris(dibenzylideneacetone)dipalladium $(0)(5 \mathrm{mg}, 0.006 \mathrm{mmol})$ at room temperature, and the mixture was stirred for $10 \mathrm{~min}$ at this temperature then vinylstannane 7 ( $245 \mathrm{mg}$, $0.552 \mathrm{mmol}$ ) was added to this solution. After the reaction mixture was stirred at $80^{\circ} \mathrm{C}$ for $1 \mathrm{~h}, 10 \%$ aqueous $\mathrm{NH}_{3}$ solution was added, and the resulting mixture was extracted with ether. The organic layers were combined, washed with brine, dried over $\mathrm{MgSO}_{4}$, filtered and concentrated in vacuo to give a 15: 1 mixture of two stereoisomers crude products. These isomers were successfully separated by column chromatography on silica gel (from $5 \%$ to $25 \%$ ethyl acetate in hexane) gave the 1,2,5,6-tetrahydropyridine derivative (-)-7a $(0.119 \mathrm{~g}, 74 \%)$ as yellow oil: Data for the major isomer (-)-7a : $[\alpha]_{D}^{27}$ $-34.3\left(c \mathrm{l} 1.02, \mathrm{CHCl}_{3}\right.$ ); IR (neat, $\mathrm{cm}^{-1}$ ) 2961, 1714, 1670, 1475, 1460, 1258, 1115, 1032; ${ }^{1} \mathrm{H}$ NMR(400 MHz, CDCl $) \delta 8.96(\mathrm{~d}, 1 \mathrm{H}, J=2.1 \mathrm{~Hz}), 8.21(\mathrm{~d}, 1 \mathrm{H}, J=2.1 \mathrm{~Hz}), 8.17$ $(\mathrm{dm}, 1 \mathrm{H}, J=8.3 \mathrm{~Hz}), 7.85(\mathrm{dd}, 1 \mathrm{H}, J=8.2,1.1 \mathrm{~Hz}), 7.76(\mathrm{ddd}, 1 \mathrm{H}, J=8.2,6.8,1.3 \mathrm{~Hz})$, $7.60(\mathrm{ddd}, 1 \mathrm{H}, J=8.0,6.8,1.1 \mathrm{~Hz}), 7.16(\mathrm{dd}, 1 \mathrm{H}, J=7.6,7.5 \mathrm{~Hz}), 6.98(\mathrm{~d}, 2 \mathrm{H}, J=8.0$ $\mathrm{Hz}), 6.82(\mathrm{dd}, 1 \mathrm{H}, J=3.4,2.3 \mathrm{~Hz}), 5.04(\mathrm{ddd}, 1 \mathrm{H}, J=5.1,5.2,2.2 \mathrm{~Hz}), 4.91(\mathrm{~d}, 1 \mathrm{H}, J=$ $5.5 \mathrm{~Hz}), 4.55(\mathrm{dd}, 1 \mathrm{H}, J=4.8,0.9 \mathrm{~Hz}), 4.36(\mathrm{dd}, 1 \mathrm{H}, J=6.2,3.4 \mathrm{~Hz}), 4.20(\mathrm{qd}, 2 \mathrm{H}, J=$ $7.1,1.4 \mathrm{~Hz}), 3.22(\mathrm{dm}, 1 \mathrm{H}, J=5.5 \mathrm{~Hz}), 2.86(\mathrm{mdd}, 1 \mathrm{H}, J=19.5,3.2 \mathrm{~Hz}), 2.78(\mathrm{dddd}$, $1 \mathrm{H}, J=19.4,11.2,4.8,2.3 \mathrm{~Hz}), 2.49$ (qq, $1 \mathrm{H}, J=6.9,6.9 \mathrm{~Hz}), 1.26(\mathrm{t}, 3 \mathrm{H}, J=7.1 \mathrm{~Hz})$, $1.0(\mathrm{~d}, 3 \mathrm{H}, J=6.9 \mathrm{~Hz}), 0.31(\mathrm{~d}, 3 \mathrm{H}, J=6.9 \mathrm{~Hz}) ;{ }^{13} \mathrm{C} \mathrm{NMR}\left(100 \mathrm{MHz}, \mathrm{CDCl}_{3}\right) \delta 165.9$, 151.8, 148.0, 147.6, 143.2, 136.8, 135.8, 135.7, 134.3, 129.7, 129.3, 128.9, 127.7, 127.6, 127.0, 125.1, 123.5, 121.7, 86.5, 75.1, 74.5, 60.8, 60.2, 39.6, 28.3, 25.5, 23.3, 22.4, 14.2; ESI HRMS $\mathrm{m} / \mathrm{z}$ calcd for $\mathrm{C}_{29} \mathrm{H}_{30} \mathrm{~N}_{2} \mathrm{O}_{3}\left[\mathrm{M}^{+}+\mathrm{Na}\right]$ 477.2154, found 477.2160; representative signals in its ${ }^{1} \mathrm{H} \mathrm{NMR}\left(400 \mathrm{MHz}, \mathrm{CDCl}_{3}\right) \delta 8.93(\mathrm{dd}, 1 \mathrm{H}, J=5.0,0.92$ $\mathrm{Hz}), 6.78(\mathrm{~d}, 1 \mathrm{H}, J=3.0 \mathrm{~Hz}), 1.14(\mathrm{~d}, 3 \mathrm{H}, J=6.6 \mathrm{~Hz})$,

One-pot reaction by using (-)-a, 4 and 8 . To a solution of the vinyliodide 4 ( $100 \mathrm{mg}$, $0.394 \mathrm{mmol})$ and molecular sieve $4 \AA(394 \mathrm{mg})$ in DMF (2 mL) was added (1S, 2R)-(-)cis-1-amino-7-isopropylindan-2-ol (-)-a (90 $\mathrm{mg}, 0.473 \mathrm{mmol})$ at room temperature, and the mixture was stirred for $30 \mathrm{~min}$ at this temperature. Then to this solution was added 
lithium chloride (33 mg, $0.788 \mathrm{mmol})$, Tri(2-furyl)phosphine (7 mg, $0.03 \mathrm{mmol})$ and Tris(dibenzylideneacetone)dipalladium $(0)(7 \mathrm{mg}, 0.008 \mathrm{mmol})$ at room temperature, and the mixture was stirred for $10 \mathrm{~min}$ at this temperature then vinylstannane $8(311 \mathrm{mg}$, $0.788 \mathrm{mmol}$ ) was added to this solution. After the reaction mixture was stirred at $80^{\circ} \mathrm{C}$ for $1 \mathrm{~h}, 10 \%$ aqueous $\mathrm{NH}_{3}$ solution was added, and the resulting mixture was extracted with ether. The organic layers were combined, washed with brine, dried over $\mathrm{MgSO}_{4}$, filtered and concentrated in vacuo to give a $16: 1$ mixture of two stereoisomers crude products. These isomers were successfully separated by column chromatography on silica gel (from 5\% to $25 \%$ ethyl acetate in hexane) gave the 1,2,5,6-tetrahydropyridine derivative (-)-8a $(0.127 \mathrm{~g}, 80 \%)$ as yellow oil: Data for the major isomer : $[\alpha]^{27}{ }_{\mathrm{D}}-50.9(\mathrm{C}$ 1.02, $\mathrm{CHCl}_{3}$ ); IR (neat, $\mathrm{cm}^{-1}$ ) 2961, 1714, 1473, 1114, 1032; ${ }^{1} \mathrm{H}$ NMR(400 MHz, $\mathrm{CDCl}_{3}$ ) $\delta 8.60(\mathrm{ddd}, 1 \mathrm{H}, J=5.0,1.8,0.92), 7.78(\mathrm{ddd}, 1 \mathrm{H}, J=7.8,7.6,1.8 \mathrm{~Hz}), 7.50(\mathrm{ddd}, 1 \mathrm{H}$, $J=7.8,2.1,1.2 \mathrm{~Hz}), 7.29(\mathrm{ddd}, 1 \mathrm{H}, J=7.6,5.0,1.2 \mathrm{~Hz}), 7.17(\mathrm{dd}, 1 \mathrm{H}, J=7.6,7.6 \mathrm{~Hz})$, $7.00(\mathrm{~d}, 1 \mathrm{H}, J=7.1 \mathrm{~Hz}), 6.99(\mathrm{~d}, 1 \mathrm{H}, J=7.3 \mathrm{~Hz}), 6.88(\mathrm{dd}, 1 \mathrm{H}, J=2.3,1.2 \mathrm{~Hz}), 5.11(\mathrm{~d}$, $1 \mathrm{H}, J=5.5 \mathrm{~Hz}), 5.02(\mathrm{ddd}, 1 \mathrm{H}, J=5.5,5.3,2.3 \mathrm{~Hz}), 4.49(\mathrm{~d}, 1 \mathrm{H}, J=4.4 \mathrm{~Hz}), 4.40(\mathrm{dd}$, $1 \mathrm{H}, J=6.4,3.4 \mathrm{~Hz}), 4.20(\mathrm{qm}, 2 \mathrm{H}, J=7.1 \mathrm{~Hz}), 3.20(\mathrm{dm}, 1 \mathrm{H}, J=5.0 \mathrm{~Hz}), 2.82(\mathrm{ddm}$, $1 \mathrm{H}, J=19.0,3.0 \mathrm{~Hz}), 2.69(\mathrm{dddm}, 1 \mathrm{H}, J=11.7,5.0,2.3), 2.51(\mathrm{qq}, 1 \mathrm{H}, J=7.1,6.9 \mathrm{~Hz})$, $1.26(\mathrm{t}, 3 \mathrm{H}, J=7.1 \mathrm{~Hz}), 1.00(\mathrm{~d}, 3 \mathrm{H}, J=6.6 \mathrm{~Hz}), 0.63(\mathrm{~d}, 3 \mathrm{H}, J=7.1 \mathrm{~Hz}),{ }^{13} \mathrm{C} \mathrm{NMR}$ $\left(100 \mathrm{MHz}, \mathrm{CDCl}_{3}\right) \delta 166.1,161.4,148.7,147.4,143.3,136.6,136.5,136.2,128.8$, $124.7,124.2,123.4,122.9,121.7,86.4,75.2,74.5,64.1,60.7,39.5,28.2,25.4,23.3$, 23.0, 14.2; ESI HRMS m/z calcd for $\mathrm{C}_{25} \mathrm{H}_{28} \mathrm{~N}_{2} \mathrm{O}_{3}\left[\mathrm{M}^{+}+\mathrm{Na}\right]$ 427.1998, found 427.1990; representative signals in its ${ }^{1} \mathrm{H} \mathrm{NMR}\left(400 \mathrm{MHz}, \mathrm{CDCl}_{3}\right) \delta 6.12(\mathrm{~d}, 1 \mathrm{H}, J=7.6 \mathrm{~Hz}), 5.57$ $(\mathrm{d}, 1 \mathrm{H}, J=7.1 \mathrm{~Hz}), 3.90(\mathrm{ddd}, 1 \mathrm{H}, J=7.8,7.6,1.8 \mathrm{~Hz})$.

One-pot reaction by using (-)-a, 4 and 9. To a solution of the vinyliodide 4 (100 $\mathrm{mg}$, $0.394 \mathrm{mmol})$ and molecular sieve $4 \AA(394 \mathrm{mg})$ in DMF $(2 \mathrm{~mL})$ was added (1S, 2R)-(-)cis-1-amino-7-isopropylindan-2-ol (-)-a (90 $\mathrm{mg}, 0.473 \mathrm{mmol})$ at room temperature, and the mixture was stirred for $30 \mathrm{~min}$ at this temperature. Then to this solution was added lithium chloride (33 mg, $0.788 \mathrm{mmol})$, Tri(2-furyl)phosphine (7 mg, $0.03 \mathrm{mmol}$ ) and Tris(dibenzylideneacetone)dipalladium $(0)(7 \mathrm{mg}, 0.008 \mathrm{mmol})$ at room temperature, and the mixture was stirred for $10 \mathrm{~min}$ at this temperature then vinylstannane $9(311 \mathrm{mg}$, $0.788 \mathrm{mmol}$ ) was added to this solution. After the reaction mixture was stirred at $80^{\circ} \mathrm{C}$ for $1 \mathrm{~h}, 10 \%$ aqueous $\mathrm{NH}_{3}$ solution was added, and the resulting mixture was extracted with ether. The organic layers were combined, washed with brine, dried over $\mathrm{MgSO}_{4}$, filtered and concentrated in vacuo to give a $17: 1$ mixture of two stereoisomers crude products. These isomers were successfully separated by column chromatography on silica gel (from 5\% to $25 \%$ ethyl acetate in hexane) gave the 1,2,5,6-tetrahydropyridine derivative (-)-9a $(0.124 \mathrm{~g}, 78 \%)$ as yellow oil: Data for the major isomer : $[\alpha]^{27}-35.8(c$ $0.3, \mathrm{CHCl}_{3}$ ); IR (neat, $\mathrm{cm}^{-1}$ ) 2959, 1712, 1476, 1030; ${ }^{1} \mathrm{H} \mathrm{NMR}\left(400 \mathrm{MH} \mathrm{Iz}, \mathrm{CDCl}_{3}\right.$ ) $\delta 8.67$ $(\mathrm{dd}, 1 \mathrm{H}, J=2.2,0.73 \mathrm{~Hz}), 8.64(\mathrm{dd}, 1 \mathrm{H}, J=4.6,1.7 \mathrm{~Hz}), 7.78(\mathrm{ddd}, 1 \mathrm{H}, J=7.8,4.2$, $2.0 \mathrm{~Hz}), 7.38(\mathrm{ddd}, 1 \mathrm{H}, J=7.8,4.6,0.73 \mathrm{~Hz}), 7.19(\mathrm{dd}, 1 \mathrm{H}, J=7.6,7.6 \mathrm{~Hz}), 7.01(\mathrm{~d}, 2 \mathrm{H}$, 
$J=7.8 \mathrm{~Hz}), 6.73(\mathrm{dd}, 1 \mathrm{H}, J=3.7,2.2 \mathrm{~Hz}), 4.99(\mathrm{ddd}, 1 \mathrm{H}, J=5.4,5.1,2.4 \mathrm{~Hz}), 4.85(\mathrm{~d}$, $1 \mathrm{H}, J=5.4 \mathrm{~Hz}), 4.49(\mathrm{~d}, 1 \mathrm{H}, J=4.1 \mathrm{~Hz}), 4.24-4.16(\mathrm{~m}, 3 \mathrm{H}), 3.21(\mathrm{dm}, 1 \mathrm{H}, J=5.1 \mathrm{~Hz})$, $2.81(\mathrm{ddm}, 1 \mathrm{H}, J=19.3,3.2 \mathrm{~Hz}), 2.70(\mathrm{dddd}, 1 \mathrm{H}, J=19.0,11.2,4.6,2.4 \mathrm{~Hz}), 2.53(\mathrm{qq}$, $1 \mathrm{H}, J=6.8,6.8 \mathrm{~Hz}), 1.27(\mathrm{l}, 3 \mathrm{H}, J=7.1 \mathrm{~Hz}), 1.04(\mathrm{~d}, 3 \mathrm{H}, J=6.8 \mathrm{~Hz}), 0.63(\mathrm{~d}, 3 \mathrm{H}, J=$ $7.1 \mathrm{~Hz}),{ }^{13} \mathrm{C}$ NMR $\left(100 \mathrm{MHz}, \mathrm{CDCl}_{3}\right) \delta 165.9,150.2,149.5,147.5,143.1,137.2,137.0$, $136.8,135.7,128.9,124.9,123.5,123.4,121.7,86.4,75.0,74.4,60.7,59.8,39.5,28.2$, 25.4, 23.3, 22.6, 14.1; ESI HRMS m/z calcd for $\mathrm{C}_{25} \mathrm{H}_{28} \mathrm{~N}_{2} \mathrm{O}_{3}\left[\mathrm{M}^{+}+\mathrm{Na}\right] 427.1998$, found 427.1991; representative signals in its ${ }^{1} \mathrm{H} \mathrm{NMR}\left(400 \mathrm{MHz}, \mathrm{CDCl}_{3}\right) \delta 6.86(\mathrm{dd}, 1 \mathrm{H}, J=$ $1.7,0.7 \mathrm{~Hz}), 1.45(\mathrm{t}, 3 \mathrm{H}, J=7.1 \mathrm{~Hz}), 0.45(\mathrm{~d}, 3 \mathrm{H}, J=7.1 \mathrm{~Hz})$.

One-pot reaction by using (-)-a, 4 and 10. To a solution of the vinyliodide 4 (100 $\mathrm{mg}$, $0.394 \mathrm{mmol})$ and molecular sieve $4 \AA$ (394 $\mathrm{mg})$ in DMF $(2 \mathrm{~mL})$ was added (1S, 2R)-(-)cis-1-amino-7-isopropylindan-2-ol (-)-a (90 $\mathrm{mg}, 0.473 \mathrm{mmol})$ at room temperature, and the mixture was stirred for $30 \mathrm{~min}$ at this temperature. Then to this solution was added lithium chloride (33 $\mathrm{mg}, 0.788 \mathrm{mmol})$, Tri(2-furyl)phosphine $(7 \mathrm{mg}, 0.03 \mathrm{mmol}$ ) and Tris(dibenzylideneacetone)dipalladium $(0)(7 \mathrm{mg}, 0.008 \mathrm{mmol})$ at room temperature, and the mixture was stirred for $10 \mathrm{~min}$ at this temperature then vinylstannane 10 (315 $\mathrm{mg}$, $0.788 \mathrm{mmol}$ ) was added to this solution. After the reaction mixture was stirred at $80^{\circ} \mathrm{C}$ for $1 \mathrm{~h}, 10 \%$ aqueous $\mathrm{NH}_{3}$ solution was added, and the resulting mixture was extracted with ether. The organic layers were combined, washed with brinc, dricd over $\mathrm{MgSO}_{4}$, filtered and concentrated in vacuo to give a 15:1 mixture of two stereoisomers crude products. These isomers were successfully separated by column chromatography on silica gel (from 5\% to $25 \%$ ethyl acetate in hexane) gave the 1,2,5,6-tetrahydropyridine derivative (-)-10a $(0.119 \mathrm{~g}, 74 \%)$ as yellow oil: Data for the major isomer : $[\alpha]^{27}{ }_{D}-51.8$ (c $0.8, \mathrm{CHCl}_{3}$ ); IR (neat, $\mathrm{cm}^{-1}$ ) 1714, 1475, 1253, 1114, 1032; ${ }^{1} \mathrm{H} \mathrm{NMR}(400 \mathrm{MHz}$, $\left.\mathrm{CDCl}_{3}\right) \delta 7.37(\mathrm{dd}, 1 \mathrm{H}, J=5.0,3.0 \mathrm{~Hz}), 7.30(\mathrm{dd}, 1 \mathrm{H}, J=3.0,1.2 \mathrm{~Hz}), 7.18(\mathrm{dd}, 1 \mathrm{H}, J=$ $7.6,7.6 \mathrm{~Hz}), 7.13(\mathrm{dd}, 1 \mathrm{H}, J=5.0,1.2 \mathrm{~Hz}), 7.03(\mathrm{~d}, 1 \mathrm{H}, J=7.6 \mathrm{~Hz}), 6.99$ (d, 1H, $J=$ $7.6 \mathrm{~Hz}), 6.79(\mathrm{dd}, 1 \mathrm{H}, J=3.7,2.1 \mathrm{~Hz}), 4.97(\mathrm{~d}, 1 \mathrm{H}, J=5.7 \mathrm{~Hz}), 4.95(\mathrm{dd}, 1 \mathrm{H}, J=5.7$, $2.1 \mathrm{~Hz}), 4.45(\mathrm{~d}, 1 \mathrm{H}, J=4.4 \mathrm{~Hz}), 4.28(\mathrm{dd}, 1 \mathrm{H}, J=6.0,3.7 \mathrm{~Hz}), 4.19(\mathrm{mq}, 2 \mathrm{H}, J=7.6$ $\mathrm{Hz}), 3.20(\mathrm{md}, 1 \mathrm{H}, J=6.2 \mathrm{~Hz}), 2.67-2.79(\mathrm{~m}, 3 \mathrm{H}), 1.26(\mathrm{t}, 3 \mathrm{H}, J=7.1 \mathrm{~Hz}), 1.0(\mathrm{~d}, 3 \mathrm{H}, J$ $=6.6 \mathrm{~Hz}), 0.74(\mathrm{~d}, 3 \mathrm{H}, J=7.1 \mathrm{~Hz}) ;{ }^{13} \mathrm{C} \mathrm{NMR}\left(100 \mathrm{MHz}, \mathrm{CDCl}_{3}\right) \delta$ 166.2, 147.8, 143.1, $142.4,137.7,136.3,128.8,128.2,126.0,124.3,123.5,123.3,121.6,86.5,74.9,74.4$, $60.6,57.1,39.6,28.2,25.5,23.6,22.9,14.2$, ESI HRMS m/z calcd for $\mathrm{C}_{24} \mathrm{H}_{27} \mathrm{NO}_{3} \mathrm{~S}$ $\left[\mathrm{M}^{+}+\mathrm{Na}\right]$ 432.1609, found 432.1598, representative signals in its ${ }^{1} \mathrm{H} \mathrm{NMR}(400 \mathrm{MHz}$, $\left.\mathrm{CDCl}_{3}\right) \delta 3.90(\mathrm{dd}, 1 \mathrm{H}, J=9.2,5.5 \mathrm{~Hz}), 3.84(\mathrm{ddd}, 1 \mathrm{H}, J=6.0,5.7,2.8 \mathrm{~Hz}), 0.91(\mathrm{~d}, 3 \mathrm{H}$, $J=6.9 \mathrm{~Hz}$ ).

(2R)-(-)-4-Hydroxymethyl-2-phenyl-1,2,5,6-tetrahydropyridine (-)-11: To a solution of compound (-)-1a $(250 \mathrm{mg}, 0.620 \mathrm{mmol})$ of toluene $(6.2 \mathrm{~mL})$ was slowly added diisobutylaluminium hydride $(4.3 \mathrm{~mL}, 4.43 \mathrm{mmol}, 1 \mathrm{M}$ in toluene $)$ at $-78{ }^{\circ} \mathrm{C}$. After the mixture was stirred at this tempcrature for $1 \mathrm{~h}, \mathrm{H}_{2} \mathrm{O}$ and saturated aqucous potassium 
sodium tartrate tetrahydrate solution was carefully added, and the resulting mixture was extracted with diethyl ether. The organic layers were combined, washed with brine, dried over $\mathrm{MgSO}_{4}$, filtered, and concentrated in vacuo to give the crude products. Column chromatofraphy on silica gel (20\% to $50 \%$ ethyl acetate in hexane) gave the diol (196 mg, 87\%) as a colorless oil.

To a solution of diol obtained above $(100 \mathrm{mg}, 0.275 \mathrm{mmol})$ in $\mathrm{CHCl}_{3}(2.8 \mathrm{~mL})$ was added n-propylamine $(0.22 \mathrm{~mL})$ and lead tetraacetate $(396 \mathrm{mg}, 0.893 \mathrm{mmol})$ at $-50{ }^{\circ} \mathrm{C}$. After the mixture was stirred at this temperature for $30 \mathrm{~min}$, added to ice- $1 \mathrm{~N}$ aqueous $\mathrm{NaOH}$ solution and the resulting mixture was extracted with chloroform. 'The organic layers were combined, washed with brine, dried over $\mathrm{MgSO}_{4}$, filtered, and concentrated in vacuo to give the crude products. Column chromatofraphy on silica gel (from $0 \%$ to $20 \%$ methanol in chloroform) gave the (-)-11 (45 mg, 87\%) as yellow oil: $[\alpha]^{19}{ }_{\mathrm{D}}-67.4$ (c $\left.0.8, \mathrm{CHCl}_{3}\right)$; IR(neat, $\left.\mathrm{cm}^{-1}\right) 3424,1051,1032 ;{ }^{1} \mathrm{H} \mathrm{NMR}\left(400 \mathrm{M} \mathrm{Hz}, \mathrm{CDCl}_{3}\right) \delta 7.36-$ 7.24 (m, 5H), 5.72 (brs, 1H), 4.50 (brs, 1H), 4.07 (brs, 2H), 3.14 (ddd, 1H, $J=12.2,5.1$, $5.1 \mathrm{~Hz}$ ), 2.95 (ddd, $1 \mathrm{H}, J=13.2,8.3,4.9 \mathrm{~Hz}), 2.68$ (brs, $2 \mathrm{H}), 2.28-2.20(\mathrm{~m}, 1 \mathrm{H}), 2.10$ (brd, $1 \mathrm{H}, J=17.3 \mathrm{~Hz}) ;{ }^{13} \mathrm{C} \mathrm{NMR}\left(100 \mathrm{M} \mathrm{Hz}, \mathrm{CDCl}_{3}\right) \delta \quad 142.7,137.6,128.5,127.8$, 127.5, 123.6, 66.4, 57.9, 41.3, 25.6; EI HRMS m/e calcd. For $\mathrm{C}_{12} \mathrm{H}_{15} \mathrm{NO}\left(\mathrm{M}^{\prime}\right)$ 189.1153, found 189.1160 .

\section{(2S)-(-)-4-Hydroxymethyl-2-( $N$-p-toluenesulfonylindol-3-yl)-1,2,5,6-}

tetrahydropyridine (-)-12 : To a solution of compound (-)-5a (206 $\mathrm{mg}, 0.345 \mathrm{mmol})$ of toluene $(3.5 \mathrm{~mL})$ was slowly added diisobutylaluminium hydride $(2.4 \mathrm{~mL}, 2.42 \mathrm{mmol}$, $1 \mathrm{M}$ in toluene) at $-78{ }^{\circ} \mathrm{C}$. After the mixture was stirred at this temperature for $1 \mathrm{~h}, \mathrm{H}_{2} \mathrm{O}$ and saturated aqueous potassium sodium tartrate tetrahydrate solution was carefully added, and the resulting mixture was extracted with diethyl ether. The organic layers were combined, washed with brine, dried over $\mathrm{MgSO}_{4}$, filtered, and concentrated in vacuo to give the crude products. Column chromatofraphy on silica gel (20\% to $50 \%$ ethyl acetate in hexane) gave the diol $(144 \mathrm{mg}, 75 \%)$ as a colorless oil.

To a solution of diol obtained above $(144 \mathrm{mg}, 0.259 \mathrm{mmol})$ in $\mathrm{CHCl}_{3}(2.6 \mathrm{~mL})$ was added n-propylamine $(0.11 \mathrm{~mL}, 1.30 \mathrm{mmol})$ and lead tetraacetate $(345 \mathrm{mg}, 0.777 \mathrm{mmol})$ at $-50{ }^{\circ} \mathrm{C}$. After the mixture was stirred at this temperature for $30 \mathrm{~min}$, added to ice- $1 \mathrm{~N}$ aqueous $\mathrm{NaOH}$ solution and the resulting mixture was extracted with chloroform. The organic layers were combined, washed with brine, dried over $\mathrm{MgSO}_{4}$, filtered, and concentrated in vacuo to give the crude products. Column chromatofraphy on silica gel (from 0\% to 20\% methanol in chloroform) gave the (-)-12 (92 $\mathrm{mg}, 93 \%)$ as white foam: $[\alpha]_{D}^{27}-33.0\left(c 0.3, \mathrm{CHCl}_{3}\right) ; \mathrm{IR}\left(\mathrm{KBr}, \mathrm{cm}^{-1}\right) 3414,2924,1597,1449,1370,1175 ;{ }^{1} \mathrm{H}$ $\operatorname{NMR}\left(400 \mathrm{MHz}, \mathrm{CDCl}_{3}\right) \delta 7.96(\mathrm{~d}, 1 \mathrm{H}, J=8.3 \mathrm{~Hz}), 7.77(\mathrm{~d}, 1 \mathrm{H}, J=8.5 \mathrm{~Hz}), 7.62(\mathrm{~d}$, $1 \mathrm{H}, J=7.8 \mathrm{~Hz}), 7.50(\mathrm{~s}, 1 \mathrm{H}), 7.32-7.20(\mathrm{~m}, 4 \mathrm{H}), 5.83(\mathrm{~s}, 1 \mathrm{H}), 4.80(\mathrm{~s}, 1 \mathrm{H}), 4.10(\mathrm{~s}, 2 \mathrm{H})$, 3.09-3.04 (m, 1H), 2.99-2.93 (m, 1H), 2.68 (brs, 1H), 2.32 (s, 3H), 2.19 (brd, $1 \mathrm{H}) ;{ }^{13} \mathrm{C}$ $\operatorname{NMR}\left(100 \mathrm{MHz}, \mathrm{CDCl}_{3}\right) \delta 145.0,138.3,135.5,129.9,129.3,126.9,124.9,124.3,123.3$, $121.7,119.9,113.7,66.3,49.5,40.5,29.7,25.6,21.5$; EI HRMS m/e calcd for 
$\mathrm{C}_{12} \mathrm{H}_{15} \mathrm{NO}\left[\mathrm{M}^{+}\right] 382.1350$, found 382.1354 .

(2S)-(-)-4-Hydroxymethyl-2-( $N$-benzensulfonylindol-2-yl)-1,2,5,6-

tetrahydropyridine (-)-13 : To a solution of compound (-)-6a (123 mg, $0.211 \mathrm{mmol})$ of toluene $(2.1 \mathrm{~mL})$ was slowly added diisobutylaluminium hydride $(1.5 \mathrm{~mL} .1 .48 \mathrm{mmol}$, $1 \mathrm{M}$ in toluene) at $-78{ }^{\circ} \mathrm{C}$. After the mixture was stirred at this temperature for $1 \mathrm{~h}, \mathrm{H}_{2} \mathrm{O}$ and saturated aqueous potassium sodium tartrate tetrahydrate solution was carefully added, and the resulting mixture was extracted with diethyl ether. The organic layers were combined, washed with brine, dried over $\mathrm{MgSO}_{4}$, filtered, and concentrated in vacuo to give the crude products. Column chromatofraphy on silica gel (20\% to $50 \%$ ethyl acetate in hexane) gave the diol (92 $\mathrm{mg}, 80 \%)$ as a colorless oil.

To a solution of diol obtained above $(92 \mathrm{mg}, 0.170 \mathrm{mmol})$ in $\mathrm{CHCl}_{3}(1.7 \mathrm{~mL})$ was added $\mathrm{n}$-propylamine $(0.07 \mathrm{~mL}, 0.85 \mathrm{mmol})$ and lead tetraacetate $(226 \mathrm{mg}, 0.510 \mathrm{mmol})$ at $-50{ }^{\circ} \mathrm{C}$. After the mixture was stirred at this temperature for $30 \mathrm{~min}$, added to ice- $1 \mathrm{~N}$ aqueous $\mathrm{NaOH}$ solution and the resulting mixture was extracted with chloroform. The organic layers were combined, washed with brine, dried over $\mathrm{MgSO}_{4}$, filtered, and concentrated in vacuo to give the crude products. Column chromatofraphy on silica gel (from $0 \%$ to $20 \%$ methanol in chloroform) gave the (-)-13 $(57 \mathrm{mg}, 91 \%)$ as yellow foum: $[\alpha]_{D}^{27}-92.3\left(c 0.3, \mathrm{CHCl}_{3}\right)$; IR $\left(\mathrm{KBr}, \mathrm{cm}^{-1}\right) 3346,1448,1369,1172,1128 ;{ }^{1} \mathrm{H}$ $\operatorname{NMR}\left(400 \mathrm{MHz}, \mathrm{CDCl}_{3}\right) \delta 8.19(\mathrm{~d}, 1 \mathrm{H}, J=8.5 \mathrm{~Hz}), 7.77(\mathrm{ddd}, 2 \mathrm{H}, J=8.2,2.3,1.4 \mathrm{~Hz})$, $7.51(\mathrm{ddm}, 1 \mathrm{H}, J=8.1,7.3 \mathrm{~Hz}), 7.44(\mathrm{dd}, 1 \mathrm{H}, J=7.3,0.7 \mathrm{~Hz}), 7.39(\mathrm{ddd}, 2 \mathrm{H}, J=8.5$, $7.6,1.3 \mathrm{~Hz}), 7.30(\mathrm{ddd}, 1 \mathrm{H}, J=8.4,7.3,1.2 \mathrm{~Hz}), 7.23(\mathrm{ddm}, 1 \mathrm{H}, J=7.6,0.7 \mathrm{~Hz}), 6.55(\mathrm{~s}$, $1 \mathrm{H}), 5.80(\mathrm{dd}, 1 \mathrm{H}, J=3.2,1.6), 5.14(\mathrm{~m}, 1 \mathrm{H}), 4.13(\mathrm{~s}, 2 \mathrm{H}), 2.85-2.96(\mathrm{~m}, 2 \mathrm{H}), 2.30-$ 2.60 (brs, $2 \mathrm{H}), 2.22$ (dd, $1 \mathrm{H}, J=16.5,6.6 \mathrm{~Hz}), 2.05(\mathrm{dm}, 1 \mathrm{H}, J=17.2 \mathrm{~Hz}),{ }^{13} \mathrm{C}$ NMR $\left(100 \mathrm{MHz}, \mathrm{CDCl}_{3}\right) \delta 141.3,139.3,138.8,137.6,133.8,129.3,129.0$ 126.2 124.8, 123.8, $120.9,120.7,114.9,112.4,66.2,49.9,38.3,26.1$; ESI HRMS $m / z$ calcd for $\mathrm{C}_{20} \mathrm{H}_{20} \mathrm{~N}_{2} \mathrm{O}_{3} \mathrm{~S}$ $\left[\mathrm{M}^{+}+\mathrm{Na}\right]$ 369.1273, found 369.1262.

(2S)-(-)-4-Hydroxymethyl-2-(3-quinolyl)-1,2,5,6-tetrahydropyridine (-)-14 : To a solution of compound (-)-7a $(85 \mathrm{mg}, 0.187 \mathrm{mmol})$ of toluene $(1.9 \mathrm{~mL})$ was slowly added diisobutylaluminium hydride $\left(1.3 \mathrm{~mL} .1 .3 \mathrm{mmol}, 1 \mathrm{M}\right.$ in toluene) at $-78^{\circ} \mathrm{C}$. After the mixture was stirred at this temperature for $1 \mathrm{~h}, \mathrm{H}_{2} \mathrm{O}$ and saturated aqueous potassium sodium tartrate tetrahydrate solution was carefully added, and the resulting mixture was extracted with diethyl ether. The organic layers were combined, washed with brine, dried over $\mathrm{MgSO}_{4}$, filtered, and concentrated in vacuo to give the crude products. Column chromatofraphy on silica gel (20\% to $50 \%$ ethyl acetate in hexane) gave the diol $(55 \mathrm{mg}, 71 \%)$ as a colorless oil.

To a solution of diol obtained above $(55 \mathrm{mg}, 0.133 \mathrm{mmol})$ in $\mathrm{CHCl}_{3}(1.3 \mathrm{~mL})$ was added n-propylamine $(0.05 \mathrm{~mL}, 0.665 \mathrm{mmol})$ and lead tetraacetate $(177 \mathrm{mg}, 0.399$ $\mathrm{mmol}$ ) at $-50{ }^{\circ} \mathrm{C}$. After the mixture was stirred at this temperature for $30 \mathrm{~min}$, added to icc-1 $\mathrm{N}$ aqucous $\mathrm{NaOH}$ solution and the resulting mixture was cxtracted with chloroform. 
The organic layers were combined, washed with brine, dried over $\mathrm{MgSO}_{4}$, filtered, and concentrated in vacuo to give the crude products. Column chromatofraphy on silica gel (from $0 \%$ to $20 \%$ methanol in chloroform) gave the (-)-14 (27 mg, 84\%) as yellow foam: $[\alpha]^{25}-44.9\left(c\right.$ 0.4, MeOH); IR ( $\mathrm{KBr}$ disk, $\left.\mathrm{cm}^{-1}\right) 3329,2946,2814,1051 ;{ }^{1} \mathrm{H}$ $\operatorname{NMR}\left(400 \mathrm{M} \mathrm{Hz}, \mathrm{CDCl}_{3}\right) \delta 8.92(\mathrm{~d}, 1 \mathrm{H}, J=1.8 \mathrm{~Hz}), 8.14(\mathrm{~m}, 1 \mathrm{H}), 8.05(\mathrm{dm}, 1 \mathrm{H}, J=$ $8.4 \mathrm{~Hz}), 7.78(\mathrm{dm}, 1 \mathrm{H}, J=8.0 \mathrm{~Hz}), 7.67(\mathrm{ddm}, 1 \mathrm{H}, J=8.1,7.3 \mathrm{~Hz}), 7.51(\mathrm{ddm}, 1 \mathrm{H}, J=$ 7.7, $7.4 \mathrm{~Hz}$ ), 5.81 (brs, 1H), 4.78 (brs, 1H), 4.15 (brs, 2H), $3.19(\mathrm{dm}, 1 \mathrm{H}, J=12.1 \mathrm{~Hz}$ ), 3.05 (ddd, 1H, $J=12.4,7.8,4.4 \mathrm{~Hz}$ ), 2.74 (brs, 2H), 2.34 (md, 1H, $J=16.8 \mathrm{~Hz}), 2.15$ (md, $1 \mathrm{H}, J=19.7 \mathrm{~Hz}),{ }^{13} \mathrm{C}$ NMR $\left(100 \mathrm{MHz}, \mathrm{CDCl}_{3}\right)$ o $151.0,147.5,139.0,134.9,129.5$, $128.9,127.8,127.8,126.8,121.7,66.1,55.6,50.7,41.3,25.3$; ESI HRMS $m / z$ calcd for $\mathrm{C}_{15} \mathrm{H}_{16} \mathrm{~N}_{2} \mathrm{O}\left[\mathrm{M}^{+}+\mathrm{H}\right] 241.1341$, found 241.1349.

(2S)-(-)-4-Hydroxymethyl-2-(2-pyridyl)-1,2,5,6-tetrahydropyridine (-)-15 : To a solution of compound (-)-8a (172 $\mathrm{mg}, 0.425 \mathrm{mmol})$ of toluene $(4.3 \mathrm{~mL})$ was slowly added diisobutylaluminium hydride $\left(3.0 \mathrm{~mL} .3 .0 \mathrm{mmol}, 1 \mathrm{M}\right.$ in toluene) at $-78^{\circ} \mathrm{C}$. After the mixture was stirred at this temperature for $1 \mathrm{~h}, \mathrm{H}_{2} \mathrm{O}$ and saturated aqueous potassium sodium tartrate tetrahydrate solution was carefully added, and the resulting mixture was extracted with diethyl ether. The organic layers were combined, washed with brine, dried over $\mathrm{MgSO}_{4}$, filtered, and concentrated in vacuo to give the crude products. Column chromatofraphy on silica gel (20\% to $50 \%$ cthyl acetate in hexanc) gave the diol (129 $\mathrm{mg}, 84 \%)$ as a colorless oil.

To a solution of diol obtained above $(129 \mathrm{mg}, 0.355 \mathrm{mmol})$ in $\mathrm{CHCl}_{3}(3.6 \mathrm{~mL})$ was added n-propylamine $(0.15 \mathrm{~mL}, 1.78 \mathrm{mmol})$ and lead tetraacetate $(472 \mathrm{mg}, 1.07 \mathrm{mmol})$ at $-50{ }^{\circ} \mathrm{C}$. After the mixture was stirred at this temperature for $30 \mathrm{~min}$, added to ice- $1 \mathrm{~N}$ aqueous $\mathrm{NaOH}$ solution and the resulting mixture was extracted with chloroform. The organic layers were combined, washed with brine, dried over $\mathrm{MgSO}_{4}$, filtered, and concentrated in vacuo to give the crude products. Column chromatofraphy on silica gel (from $0 \%$ to $20 \%$ methanol in chloroform) gave the (-)-15 (20 mg, 29\%) as yellow oil: $[\alpha]_{\mathrm{D}}^{25}-11.5\left(c\right.$ 0.4, MeOH); IR (neat, $\mathrm{cm}^{-1}$ ) 3279, 3055, 2924, 2852, 1049; ${ }^{1} \mathrm{H}$ NMR $\left(400 \mathrm{MHz}, \mathrm{CDCl}_{3}\right) \delta 8.55(\mathrm{dm}, 1 \mathrm{H}, J=4.1), 7.67(\mathrm{ddm}, 1 \mathrm{H}, J=7.8,7.6 \mathrm{~Hz}), 7.39(\mathrm{dm}$, $1 \mathrm{H}, J=7.7 \mathrm{~Hz}), 7.19(\mathrm{ddd}, 1 \mathrm{H}, J=7.1,6.2,1.1 \mathrm{~Hz}), 5.88(\mathrm{brs}, 1 \mathrm{H}), 4.66(\mathrm{brs}, 1 \mathrm{H}), 4.09$ (brs, 2H), $3.17(\mathrm{ddd}, 1 \mathrm{H}, J=16.9,11.4,5.4 \mathrm{~Hz}), 3.05(\mathrm{ddd}, 1 \mathrm{H}, J=18.0,11.7,5.6 \mathrm{~Hz})$, $2.69(\mathrm{brs}, 2 \mathrm{H}), 2.19(\mathrm{dm}, 2 \mathrm{H}, J=16.7 \mathrm{~Hz}),{ }^{13} \mathrm{C} \mathrm{NMR}\left(100 \mathrm{MHz}, \mathrm{CDCl}_{3}\right) \& 160.9,149.2$, $138.3,136.9,122.5,122.1,121.6,66.1,58.3,41.1,25.3$; ESI HRMS $m / z$ calcd for $\mathrm{C}_{11} \mathrm{H}_{14} \mathrm{~N}_{2} \mathrm{O}\left[\mathrm{M}^{+}+\mathrm{H}\right]$ 191.1184, found 191.1183.

(2S)-(-)-4-Hydroxymethyl-2-(3-pyridyl)-1,2,5,6-tetrahydropyridine (-)-16 : To a solution of compound (-)-9a $(110 \mathrm{mg}, 0.27 \mathrm{mmol})$ of toluene $(2.7 \mathrm{~mL})$ was slowly added diisobutylaluminium hydride $\left(1.9 \mathrm{~mL}, 1.9 \mathrm{mmol}, 1 \mathrm{M}\right.$ in toluene) at $-78^{\circ} \mathrm{C}$. After the mixture was stirred at this temperature for $1 \mathrm{~h}, \mathrm{H}_{2} \mathrm{O}$ and saturated aqueous potassium sodium tartrate tetrahydrate solution was carcfully added, and the resulting mixture was 
extracted with diethyl ether. The organic layers were combined, washed with brine, dried over $\mathrm{MgSO}_{4}$, filtered, and concentrated in vacuo to give the crude products. Column chromatofraphy on silica gel (20\% to $50 \%$ ethyl acetate in hexane) gave the diol $(68 \mathrm{mg}, 69 \%)$ as a colorless oil.

To a solution of diol obtained above $(56 \mathrm{mg}, 0.154 \mathrm{mmol})$ in $\mathrm{CHCl}_{3}(0.77 \mathrm{~mL})$ was added n-propylamine $(0.06 \mathrm{~mL}, 0.77 \mathrm{mmol})$ and lead tetraacetate $(205 \mathrm{mg}, 0.462 \mathrm{mmol})$ at $-50^{\circ} \mathrm{C}$. After the mixture was stirred at this temperature for $30 \mathrm{~min}$, added to ice- $1 \mathrm{~N}$ aqueous $\mathrm{NaOH}$ solution and the resulting mixture was extracted with chloroform. The organic layers were combined, washed with brine, dried over $\mathrm{MgSO}_{4}$, filtered, and concentrated in vacuo to give the crude products. Column chromatofraphy on silica gel (from 0\% to 20\% methanol in chloroform) gave the (-)-16 $(23 \mathrm{mg}, 79 \%)$ as yellow oil: $[\alpha]^{25}-24.2$ (c 1.04, MeOH); IR (neat, $\mathrm{cm}^{-1}$ ) 3277, 3059, 2919, 2835, 1425, 1049; ${ }^{1} \mathrm{H}$ $\operatorname{NMR}\left(400 \mathrm{M} \mathrm{Hz}, \mathrm{CDCl}_{3}\right) \delta 8.56(\mathrm{~m}, 1 \mathrm{H}), 8.47(\mathrm{dm}, 1 \mathrm{H}, J=3.9 \mathrm{~Hz}), 7.72(\mathrm{dm}, 1 \mathrm{H}, J=$ $7.7 \mathrm{~Hz}), 7.25(\mathrm{ddm}, 1 \mathrm{H}, J=7.7,4.8 \mathrm{~Hz}), 5.71(\mathrm{~m}, 1 \mathrm{H}), 4.56(\mathrm{~m}, 1 \mathrm{H}), 4.08(\mathrm{~s}, 2 \mathrm{H}), 3.38$ (brs, 2I), 3.14 (ddd, $1 \mathrm{H}, J=12.0,9.6,4.8 \mathrm{~Hz}), 3.00$ (ddd, $1 \mathrm{H}, J=12.6,8.5,4.8 \mathrm{~Hz}$ ), 2.31-2.23 (m, 1H), $2.09(\mathrm{dm}, 1 \mathrm{H}, J=17.9 \mathrm{~Hz}) ;{ }^{13} \mathrm{C} \mathrm{NMR}\left(100 \mathrm{M} \mathrm{Hz}, \mathrm{CDCl}_{3}\right) \delta 149.2$, $148.6,138.9,138.2,135.9,123.5,121.5,65.7,55.5,41.3,25.3$; ESI HRMS $m / z$ calcd for $\mathrm{C}_{11} \mathrm{H}_{14} \mathrm{~N}_{2} \mathrm{O}\left[\mathrm{M}^{+}+\mathrm{H}\right]$ 191.1184, found 191.1185.

(2S)-(-)-4-Hydroxymethyl-2-(3-thienyl)-1,2,5,6-tetrahydropyridine (-)-17 : To a solution of compound (-)-10a $(150 \mathrm{mg}, 0.366 \mathrm{mmol})$ of toluene $(3.7 \mathrm{~mL})$ was slowly added diisobutylaluminium hydride $\left(2.6 \mathrm{~mL}, 2.6 \mathrm{mmol}, 1 \mathrm{M}\right.$ in toluene) at $-78^{\circ} \mathrm{C}$. After the mixture was stirred at this temperature for $1 \mathrm{~h}, \mathrm{H}_{2} \mathrm{O}$ and saturated aqueous potassium sodium tartrate tetrahydrate solution was carefully added, and the resulting mixture was extracted with diethyl ether. The organic layers were combined, washed with brine, dried over $\mathrm{MgSO}_{4}$, filtered, and concentrated in vacuo to give the crude products. Column chromatofraphy on silica gel (20\% to $50 \%$ ethyl acetate in hexane) gave the diol (115 $\mathrm{mg}, 85 \%)$ as a colorless oil.

To a solution of diol obtained above $(115 \mathrm{mg}, 0.31 \mathrm{mmol})$ in $\mathrm{CHCl}_{3}(3.1 \mathrm{~mL})$ was added n-propylamine $(0.13 \mathrm{~mL}, 1.6 \mathrm{mmol})$ and lead tetraacetate $(414 \mathrm{mg}, 0.93 \mathrm{mmol})$ at $-50{ }^{\circ} \mathrm{C}$. After the mixture was stirred at this temperature for $30 \mathrm{~min}$, added to ice- $1 \mathrm{~N}$ aqueous $\mathrm{NaOH}$ solution and the resulting mixture was extracted with chloroform. The organic layers were combined, washed with brine, dried over $\mathrm{MgSO}_{4}$, filtered, and concentrated in vacuo to give the crude products. Column chromatofraphy on silica gel (from $0 \%$ to $20 \%$ methanol in chloroform) gave the (-)-17 $(52 \mathrm{mg}, 85 \%)$ as yellow oil: $[\alpha]_{D}^{25}-67.3\left(\mathrm{c} 0.5, \mathrm{CHCl}_{3}\right)$; IR ( $\mathrm{KBr}$ disk, $\left.\mathrm{cm}^{-1}\right) 3275,3123,2901,2820,1049,775 ;{ }^{1} \mathrm{H}$ $\operatorname{NMR}\left(400 \mathrm{MHz}, \mathrm{CDCl}_{3}\right) \delta 7.28(\mathrm{dd}, 1 \mathrm{H}, J=4.8,2.9 \mathrm{~Hz}), 7.14(\mathrm{~d}, 1 \mathrm{H}, J=2.1 \mathrm{~Hz}), 7.07$ (1H, $J=5.0 \mathrm{~Hz}$ ), 5.79 (brs, 1H), 4.58 (brs, 1H), 4.05 (brs, 2H), 3.10 (ddd, 1H, $J=17.9$, $12.2,5.7 \mathrm{~Hz}), 2.94$ (ddd, $1 \mathrm{H}, J=17.2,12.2,5.8 \mathrm{~Hz}), 2.49$ (m, 2H), 2.12 (dd, $1 \mathrm{H}, J=$ 14.0, $6.0 \mathrm{~Hz}) ;{ }^{13} \mathrm{C} \mathrm{NMR}\left(100 \mathrm{MHz}, \mathrm{CDCl}_{3}\right) \delta 144.2,137.5,126.9,125.9,123.2,121.6$, 66.1, 53.2, 40.9, 25.7; ESI HRMS $m / z$ calcd for $\mathrm{C}_{10} \mathrm{H}_{13} \mathrm{NOS}\left[\mathrm{M}^{+}+\mathrm{H}\right] 196.0796$, found 
196.0803. 


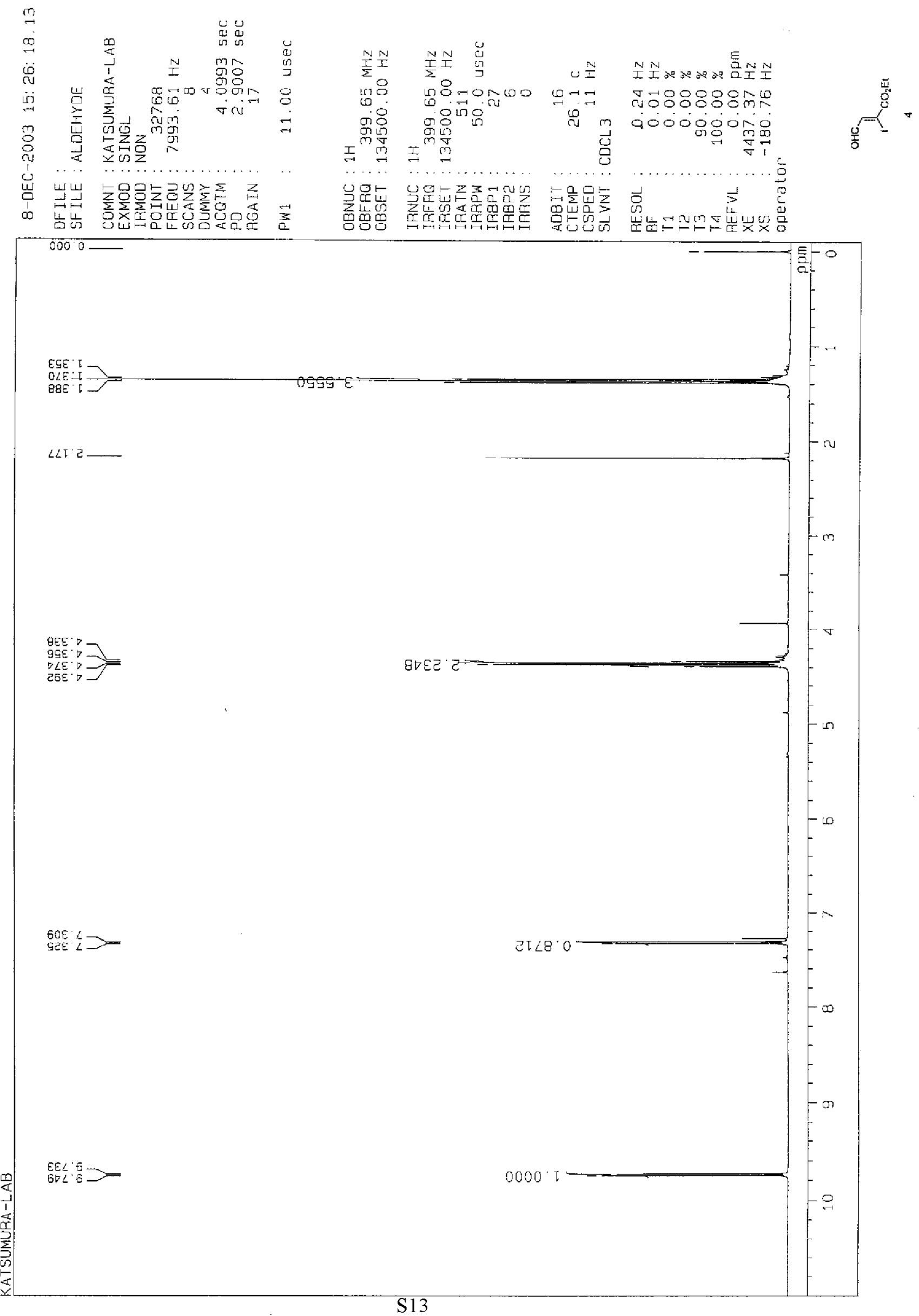




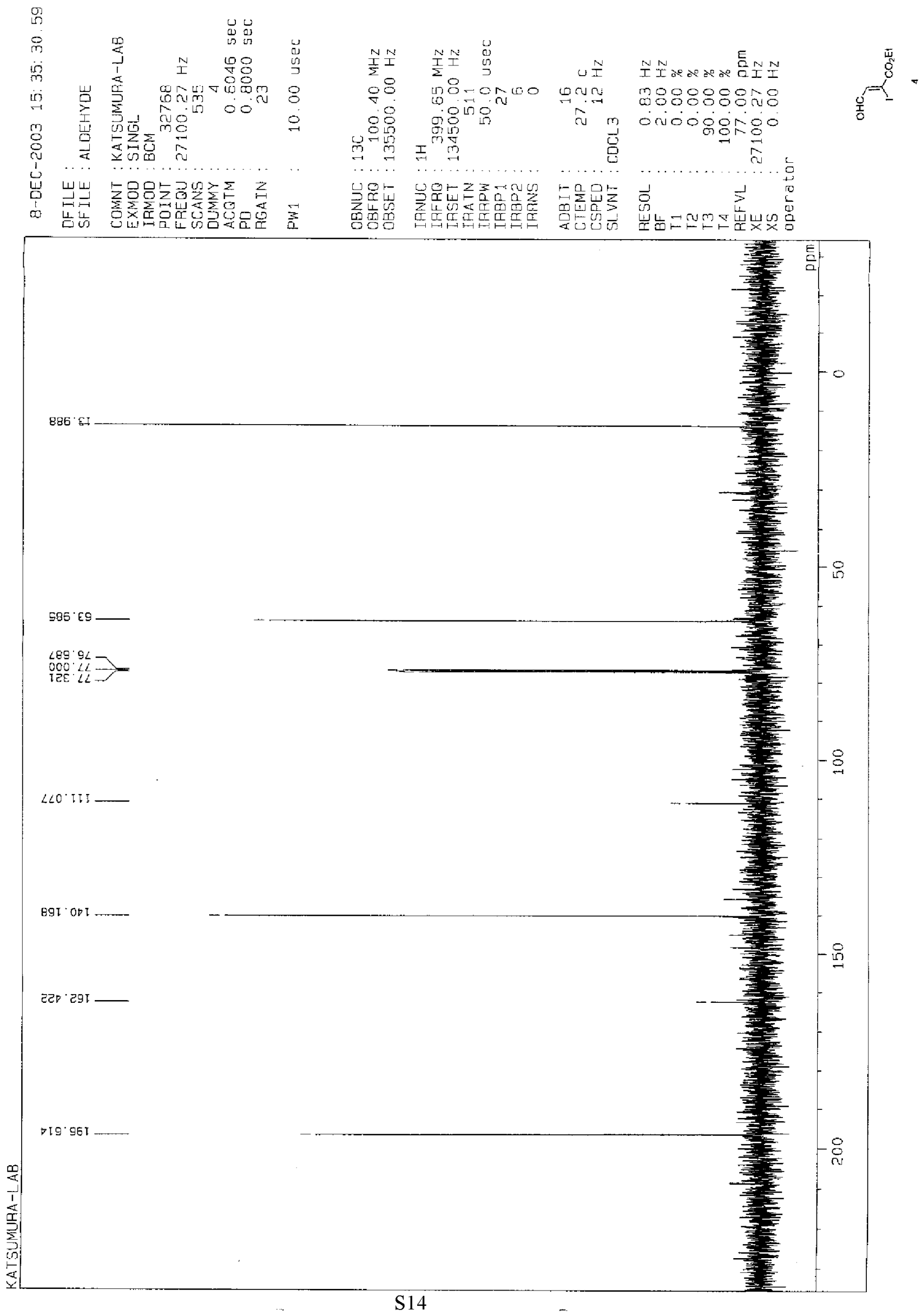


UN $N$ Nㅗㅇำ ص8 N.088888mm

98 gin 号

0000800 कुल $I \stackrel{m}{m} I \stackrel{m}{m}$

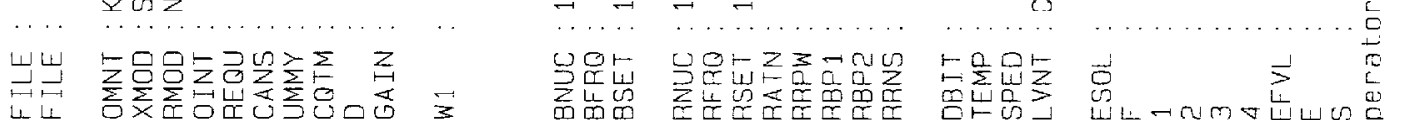

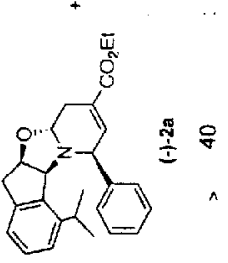

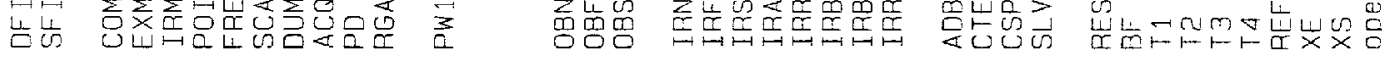

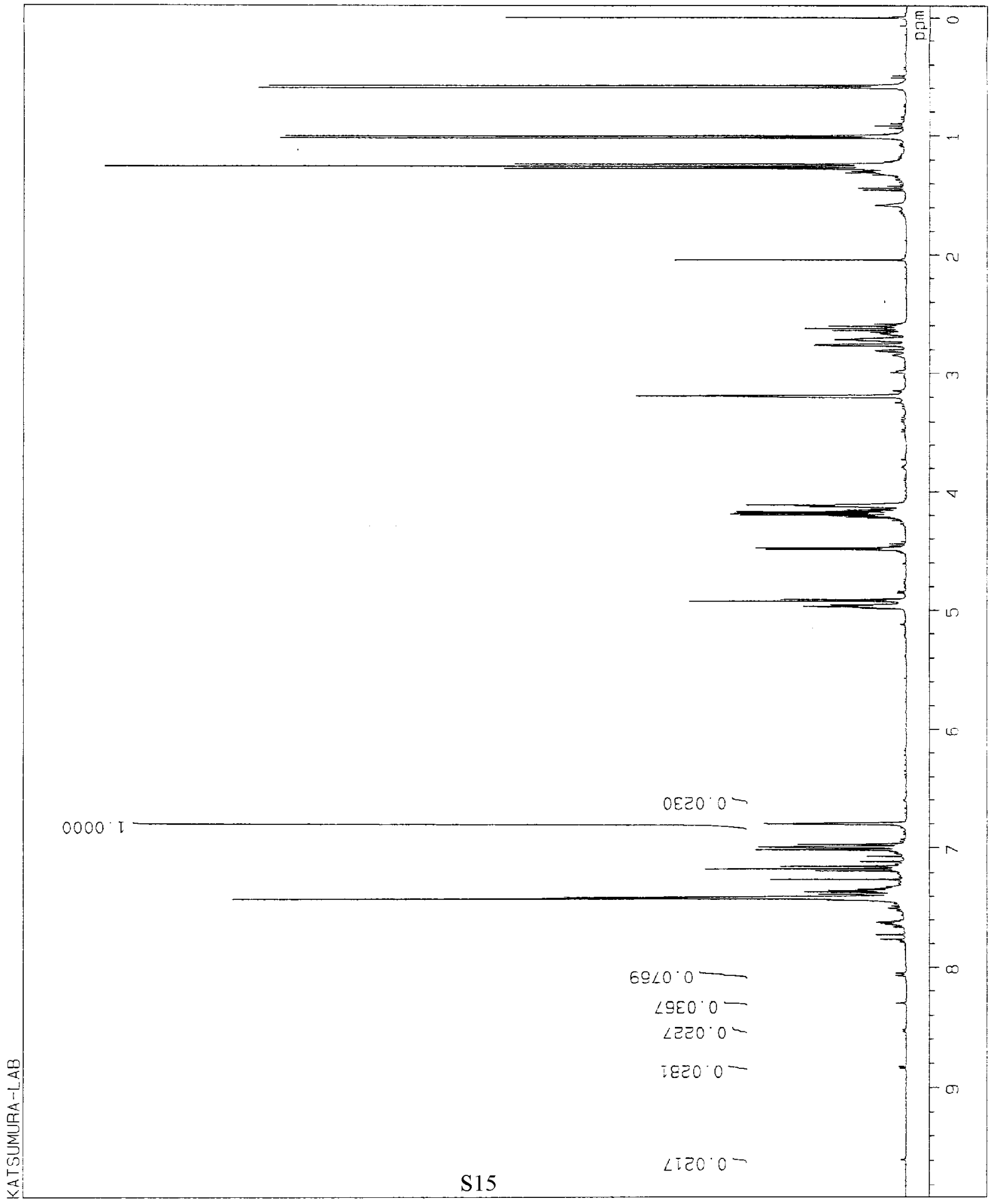




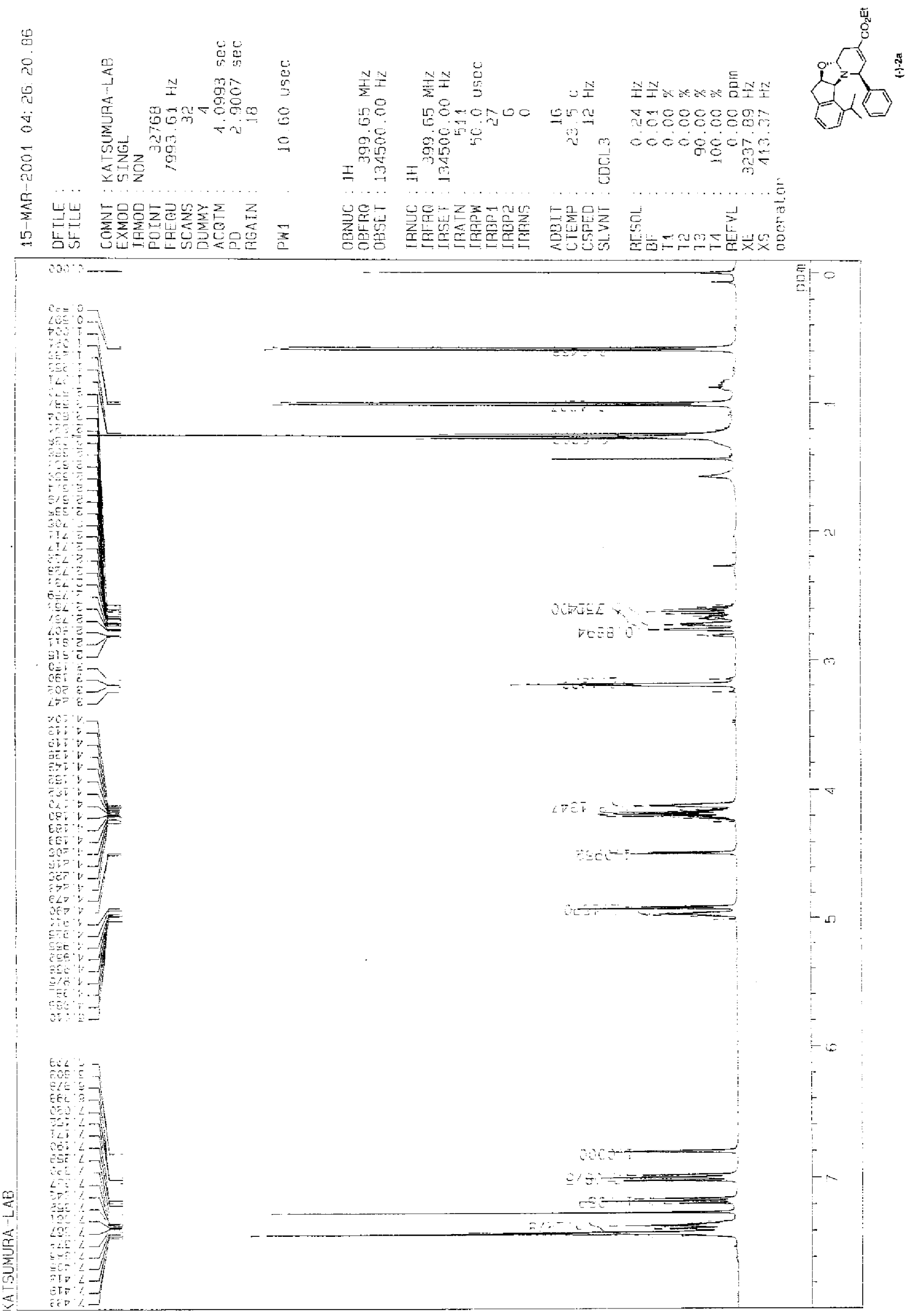




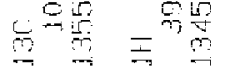

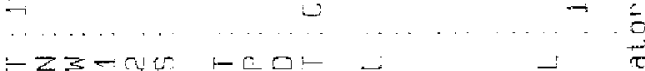

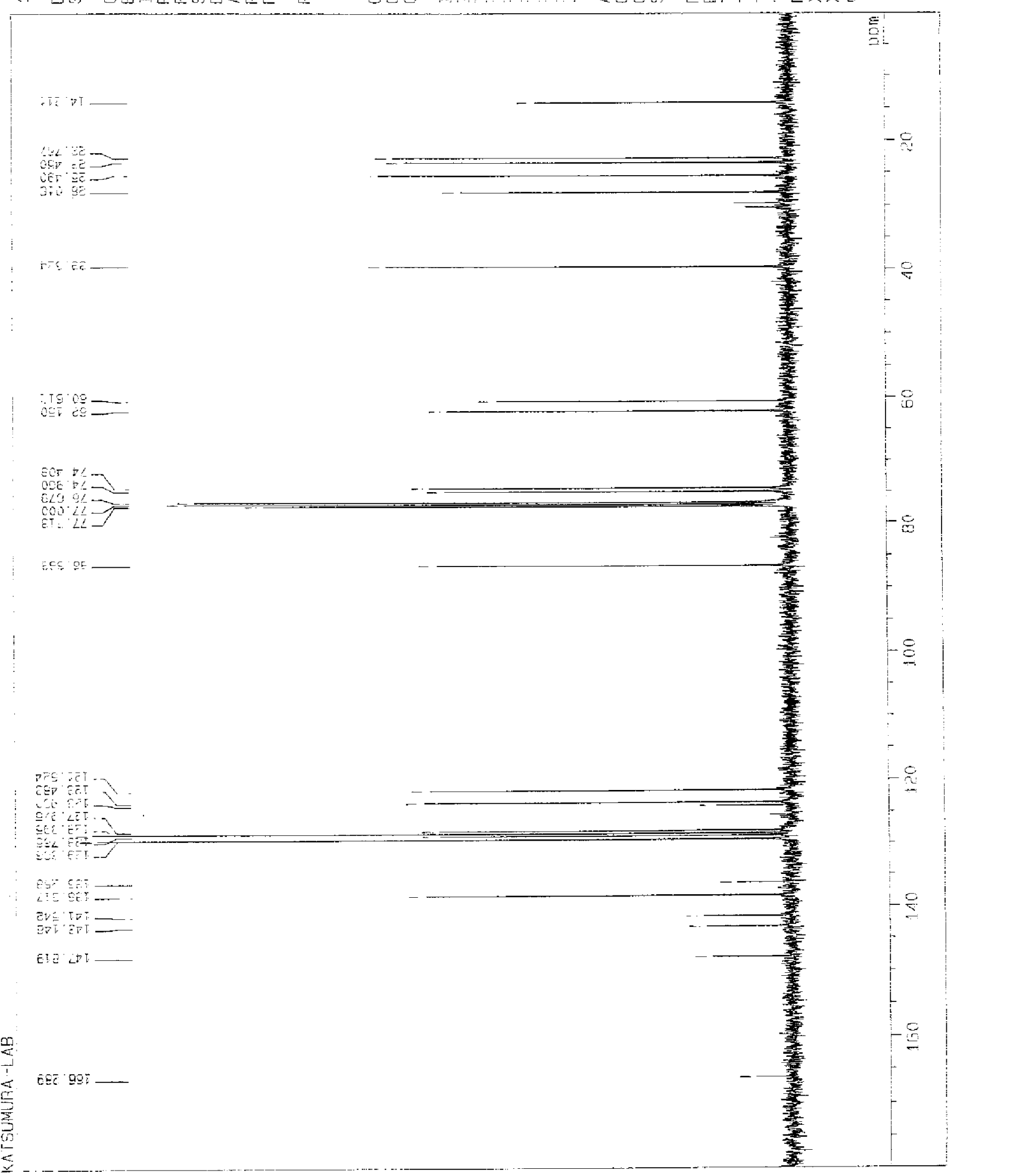



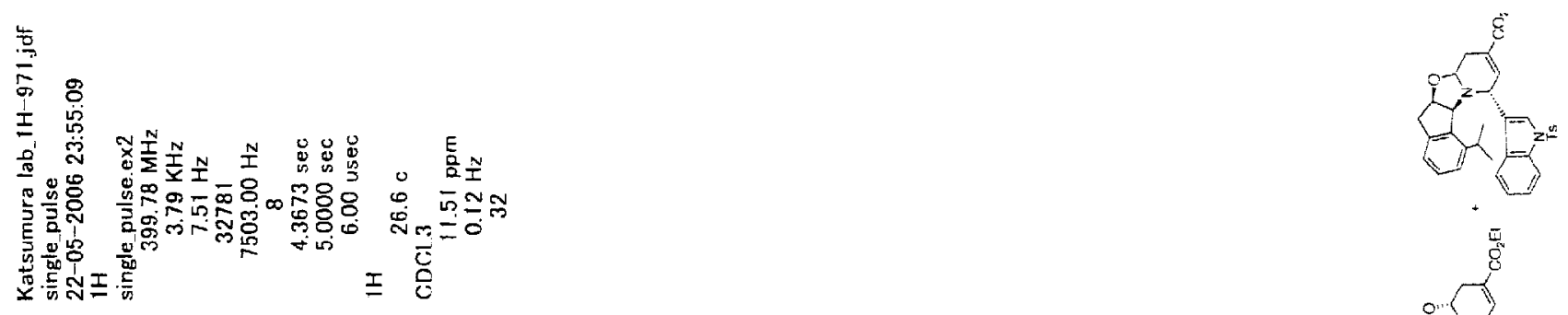

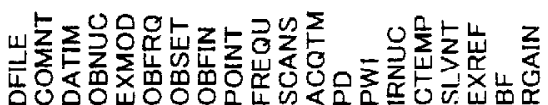
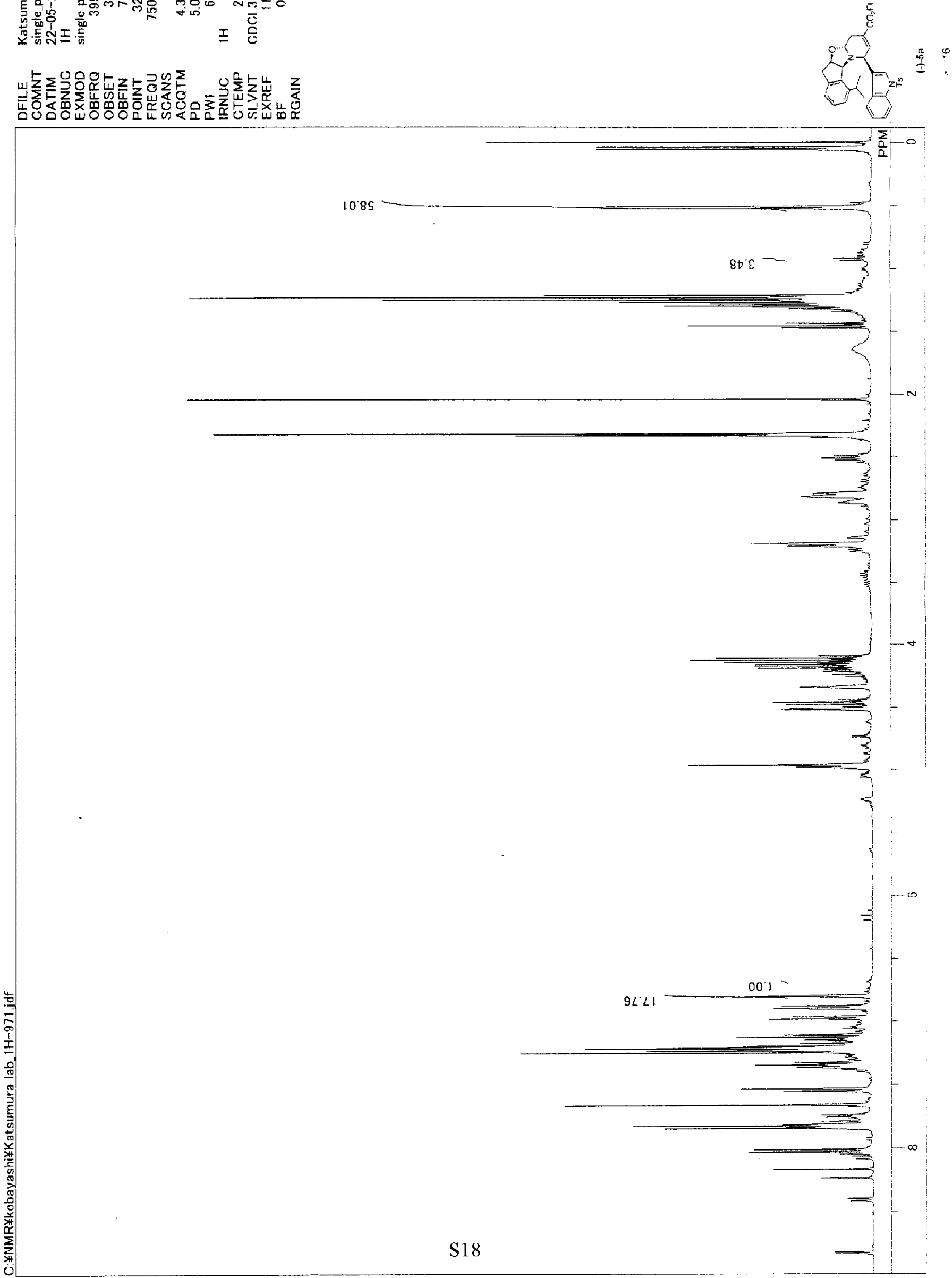


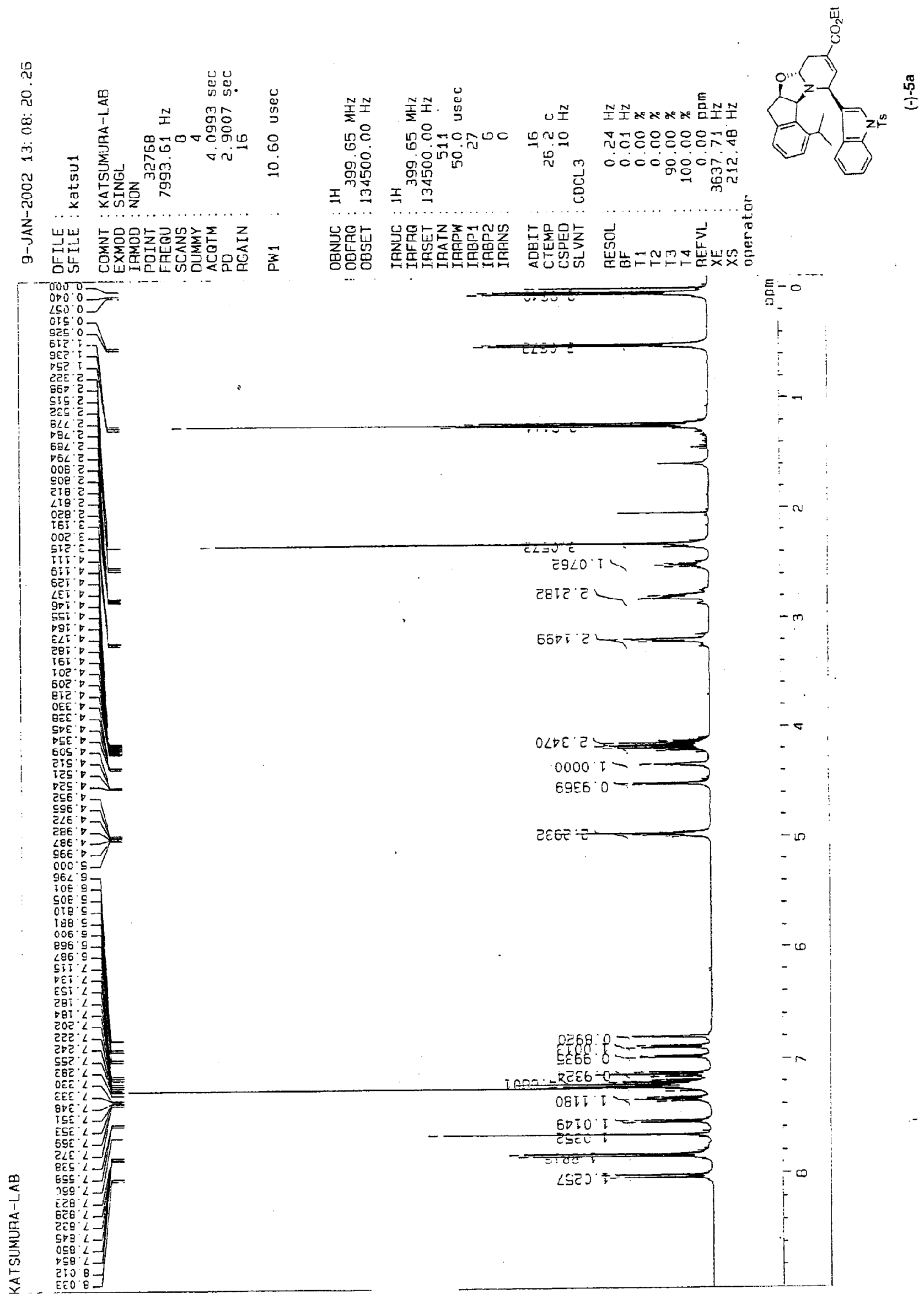




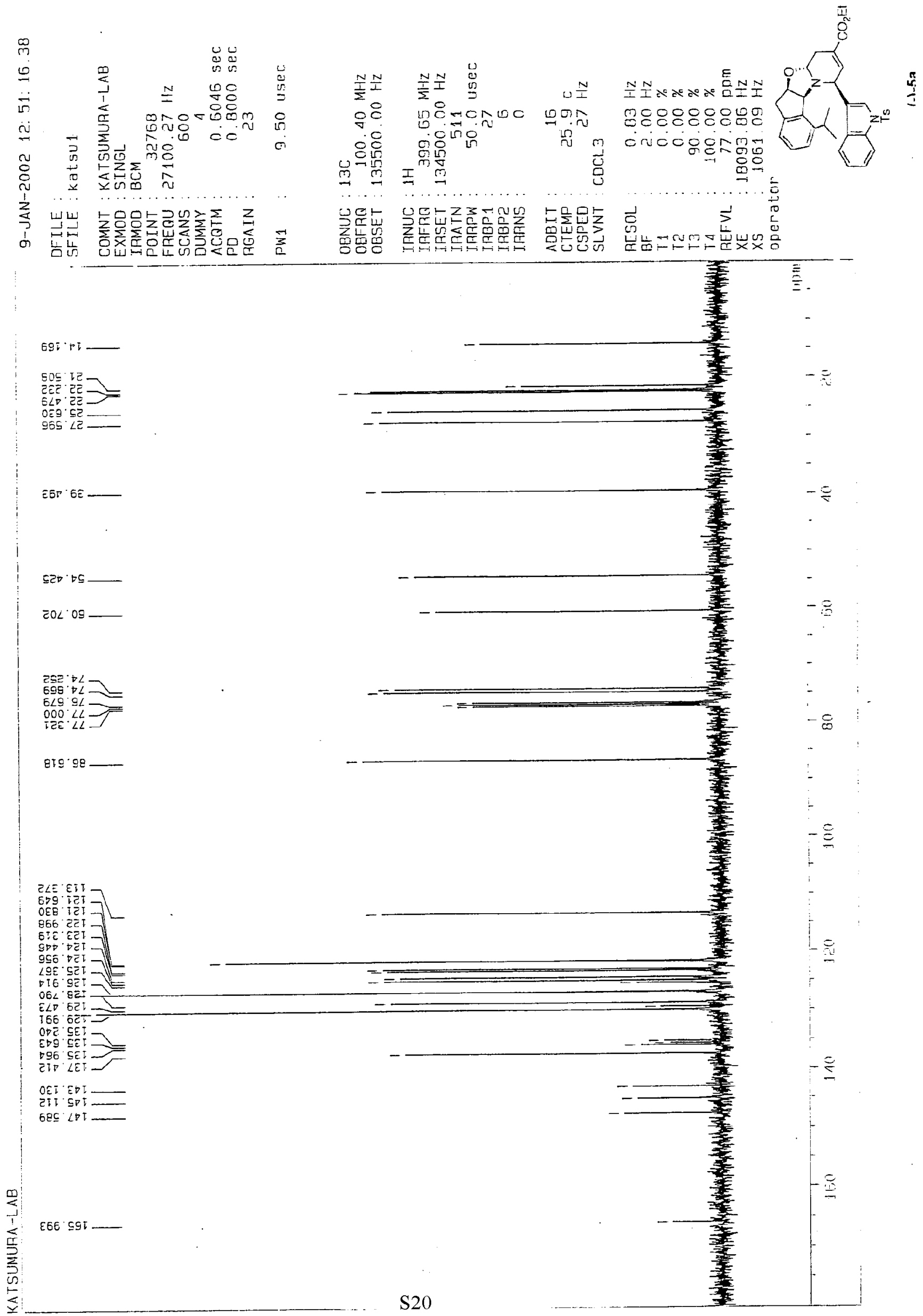




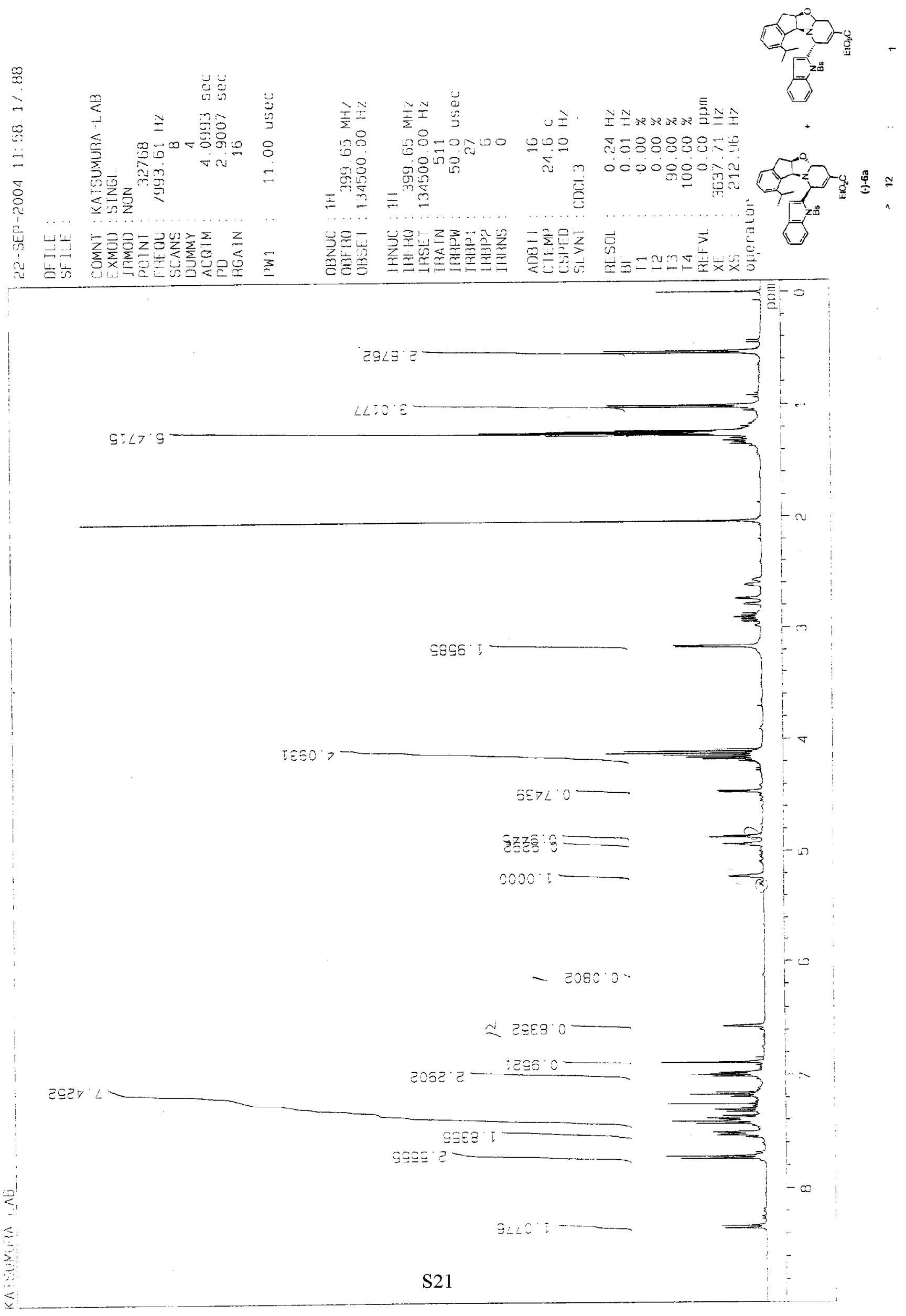




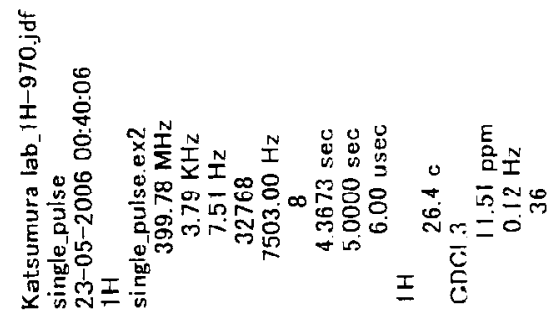

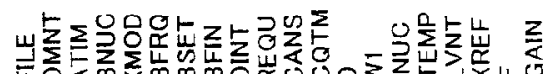

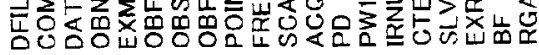

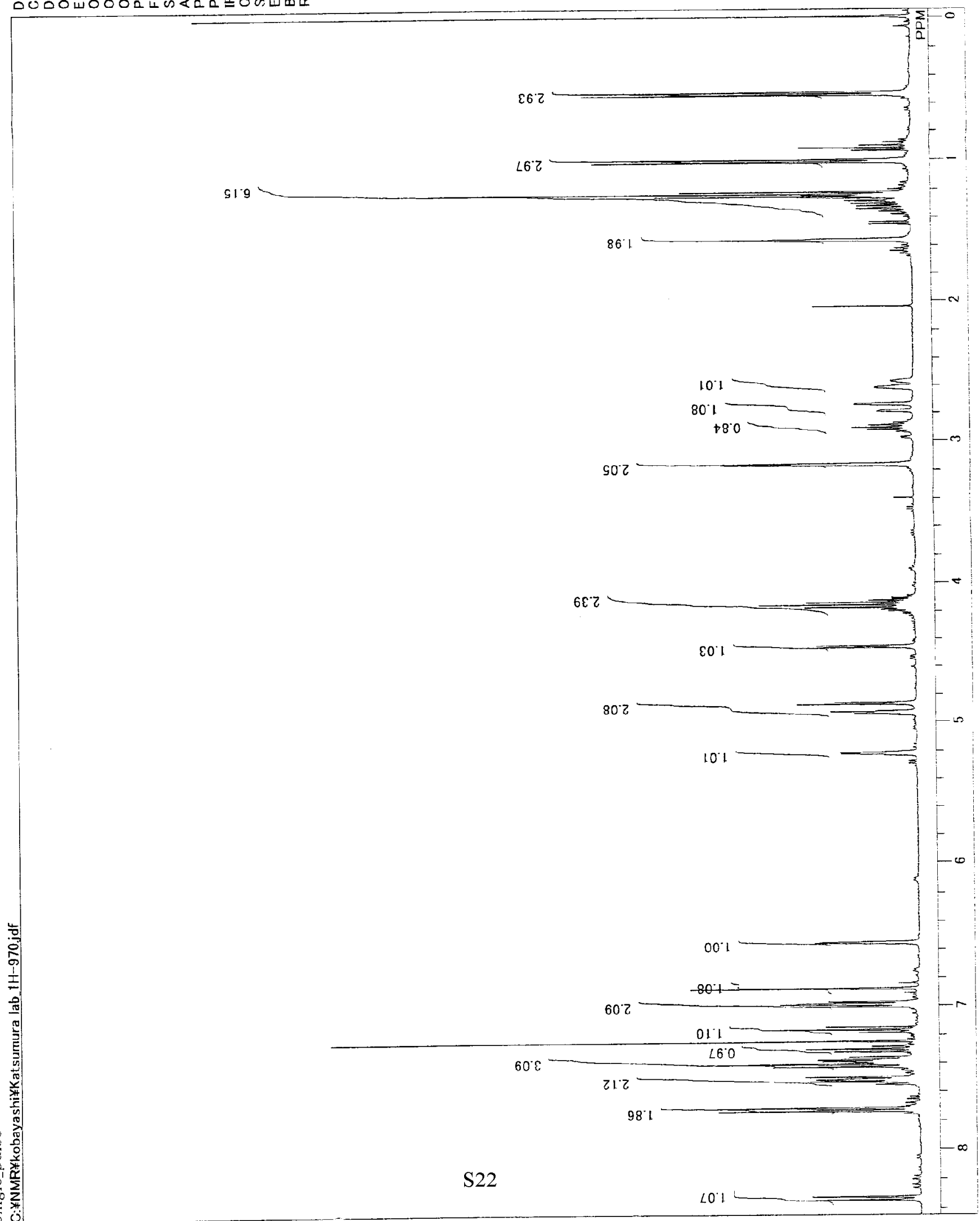


i.

兽言怘

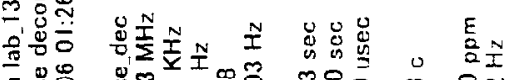

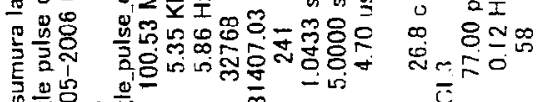

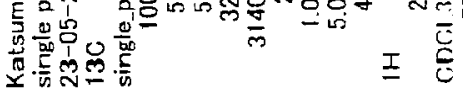

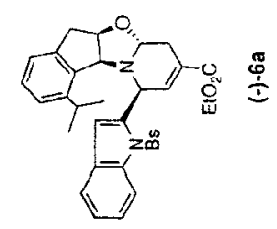

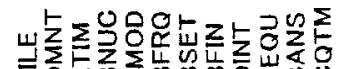

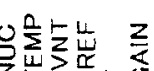

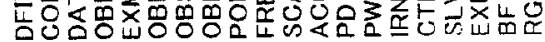

$\operatorname{soz}+1$

$\angle 86.27$

tงtez

to\&s $=$

GE!:

sIt $6 \varepsilon$

$098^{\circ} \mathrm{Cs}$

$\llcorner 9909$

$\forall \angle t S L$

$\angle Z 9^{\circ} S L$

929.92

SIE LL

$\varsigma 2 L \cdot 98$

ำ

$080+11-$

$160511=$

$S \pi \angle 0 Z 1$

SGLIZL

$29+\varepsilon z 1-2$

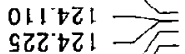

t50.5Z1

उE1.021 $]$

698821

$66 \varepsilon^{\circ} 621-/$
$6 \angle 0^{\circ} 621-$

$\varepsilon 60+\varepsilon 1-/ F$

$\rightarrow 11.981$

$6 ! z: 981$

$889 \angle \varepsilon 1$

$0 \angle 0681-1$

L6Giti-11

GLZED -

究

$S \angle S L D L-$

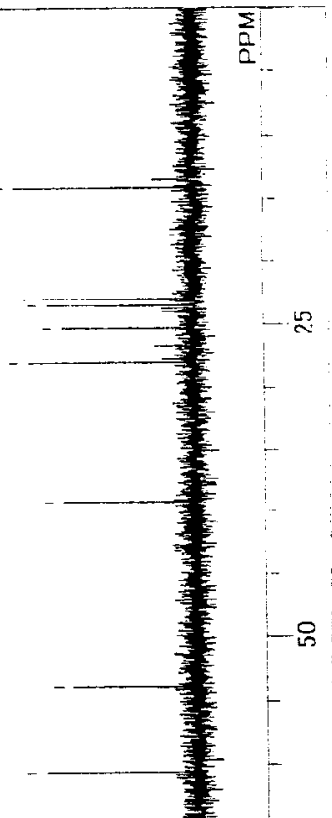

$-2$ 


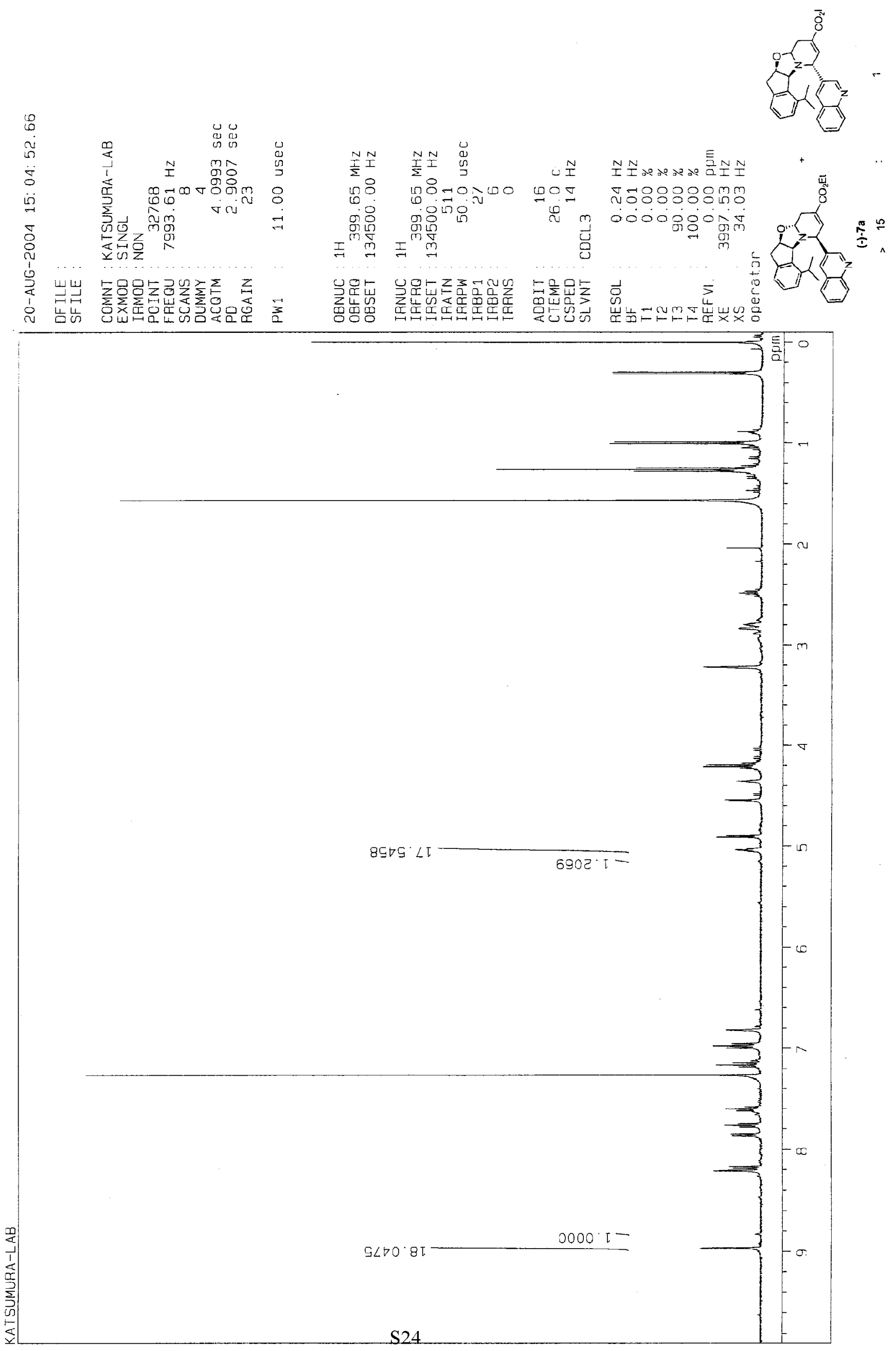




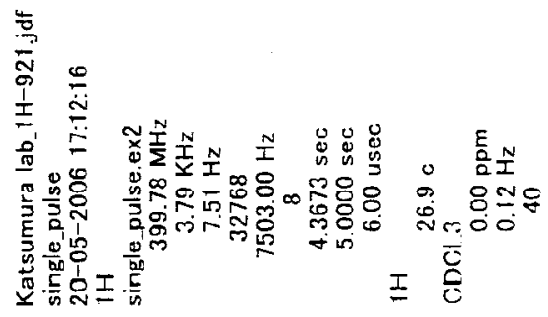

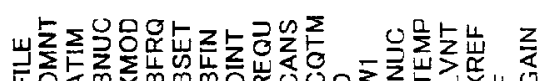

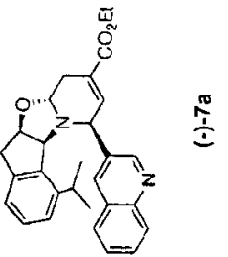

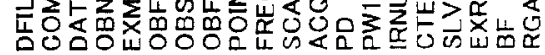

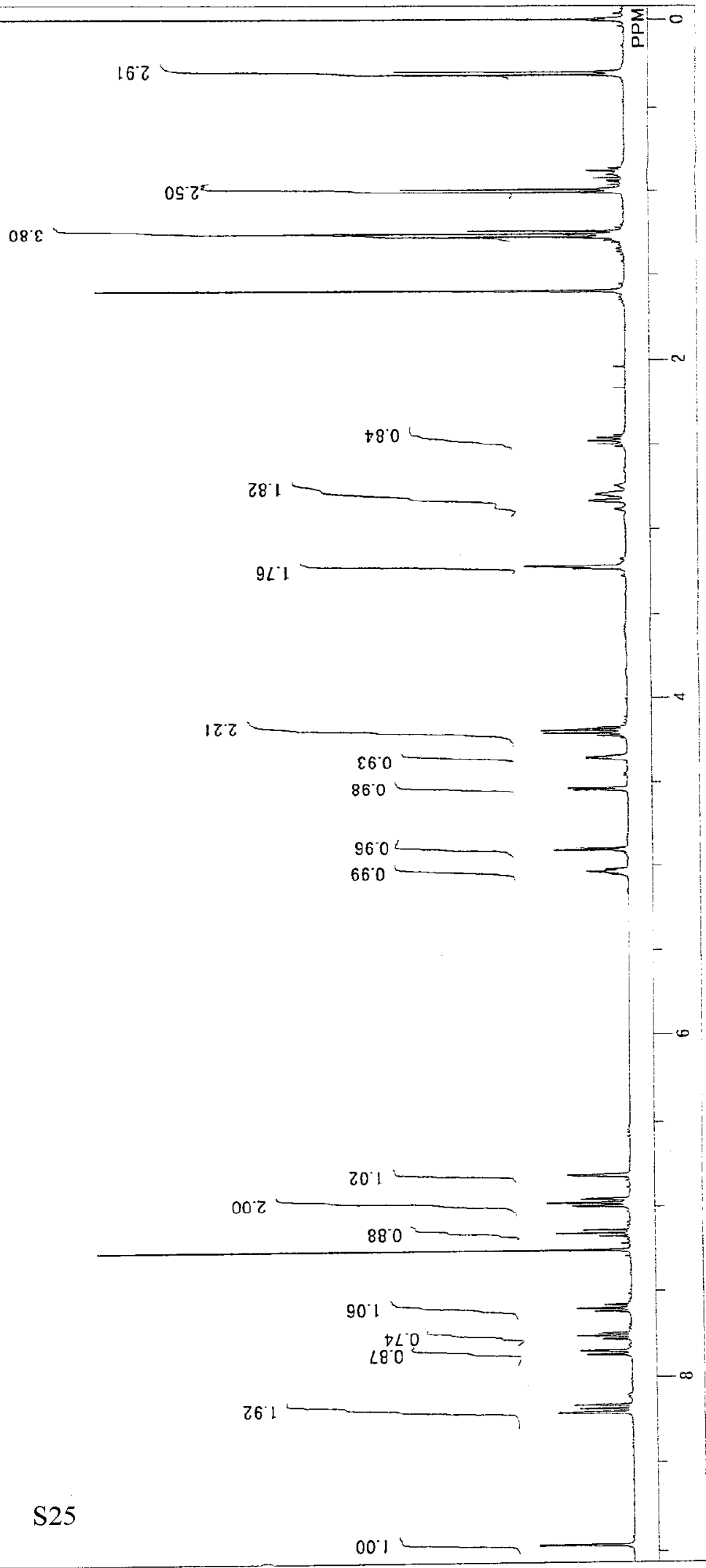




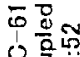

敦

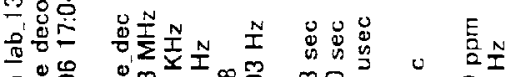

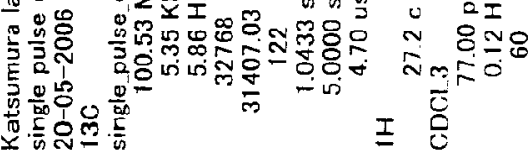

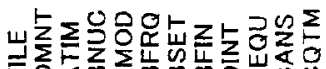

$z L t Z 2=$

$108 \cdot 22$

ztc $q 2$

$\angle 9 \mathcal{G}^{\circ} 6 \mathcal{E}$

$62209-2$
$16 L 09-7$

$\varepsilon L \nabla \nabla L$

colgL

$\mathrm{s} 89^{\circ} \mathrm{gl}$

$000 \angle L$

जIELL

48798

\section{gEL $L Z \mid$}

00siczl

880.521

$\angle E O^{\circ} \angle Z I$

¿SSLZ

telizi

$+06821-\pi$

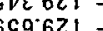

$992 \nabla \varepsilon 1=$

ILLSEI-

$608 \mathrm{gEl}-$

ZLL $L E I=-$

$9 S S^{\circ} \angle D 1-$

$66 L|S|-$

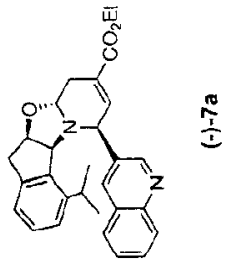

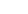




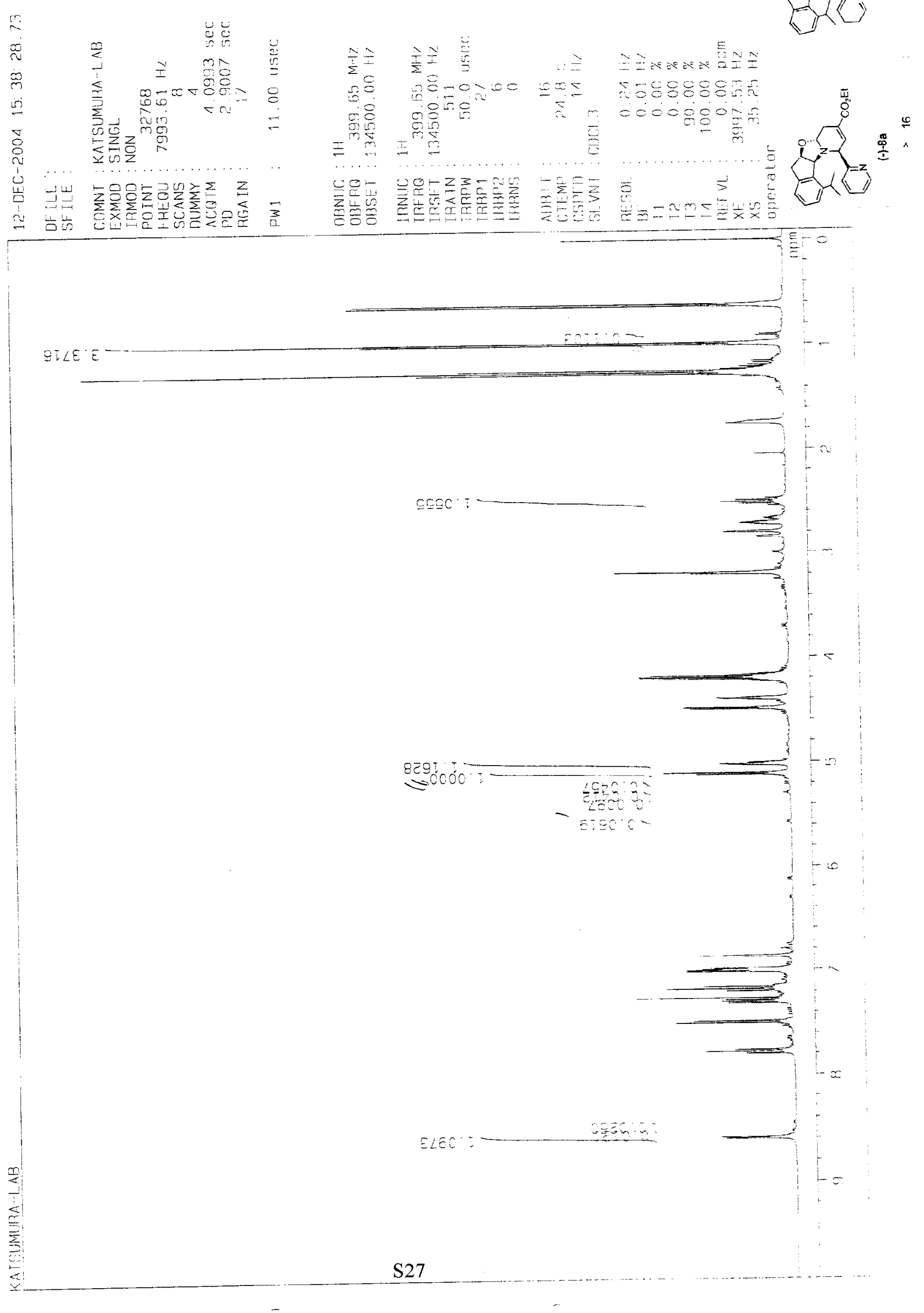


蕰

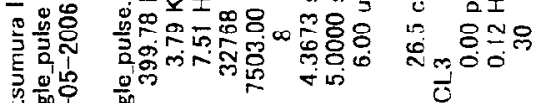

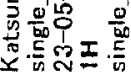

I

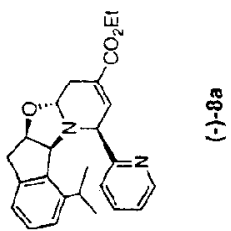

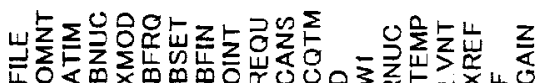

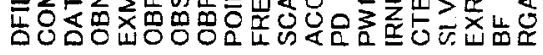

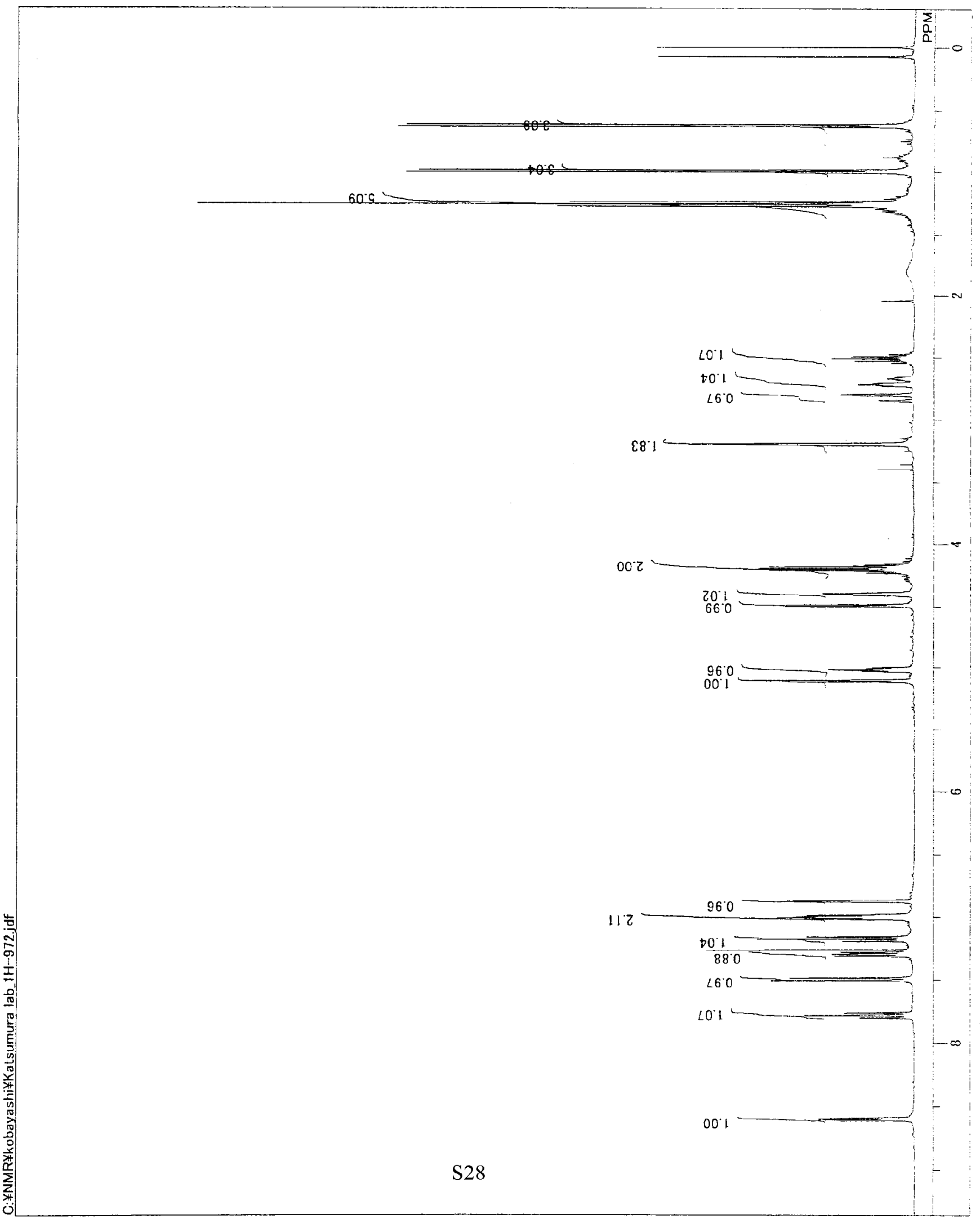


点要

o.

을

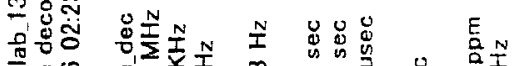

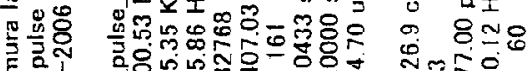

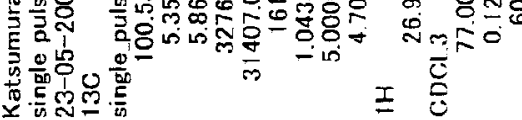

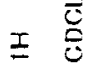

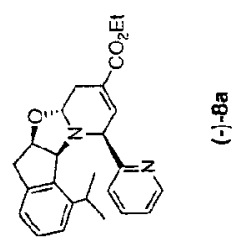

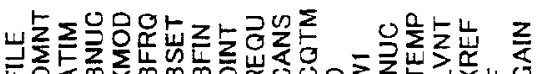

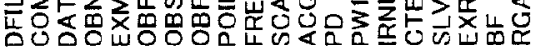

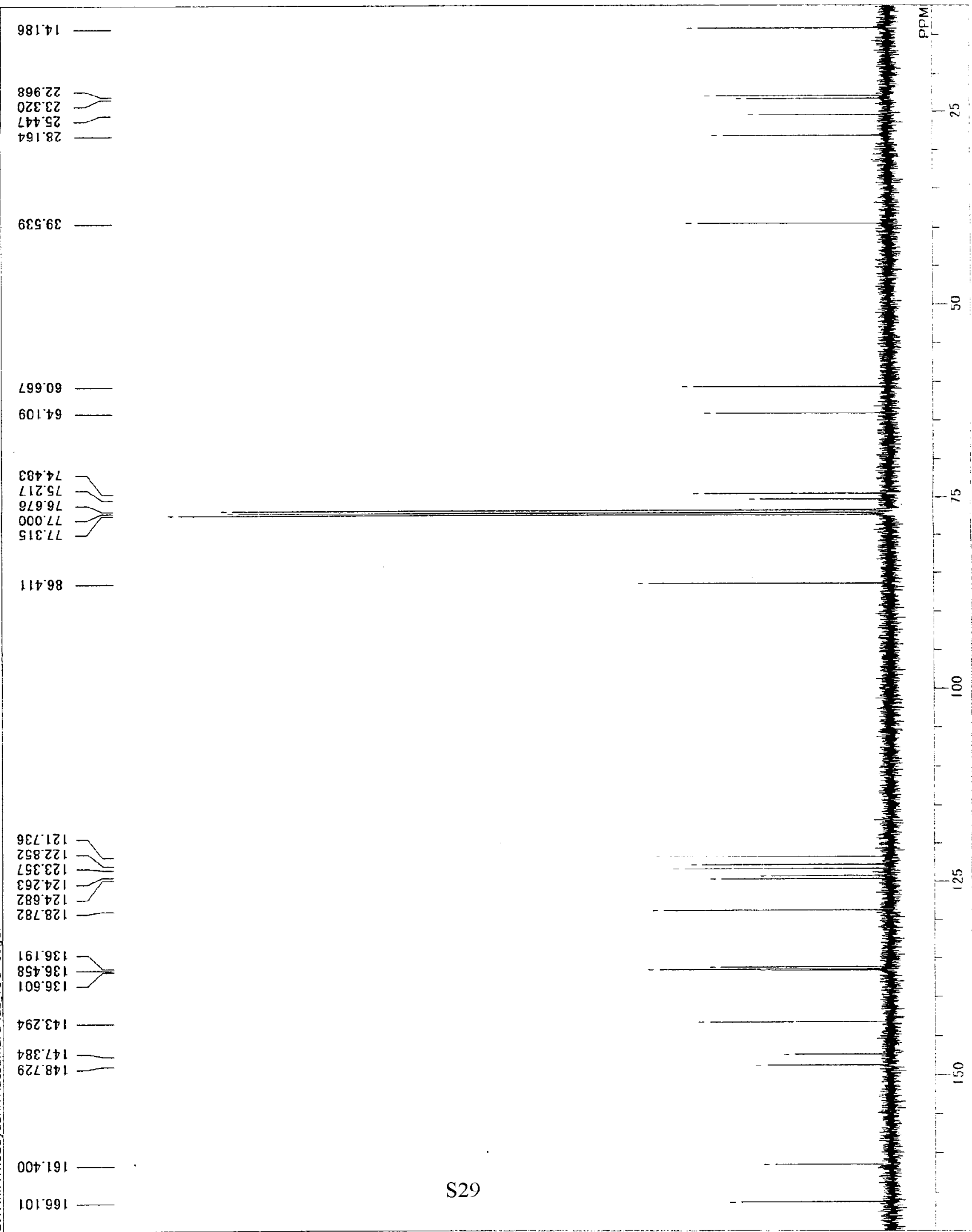




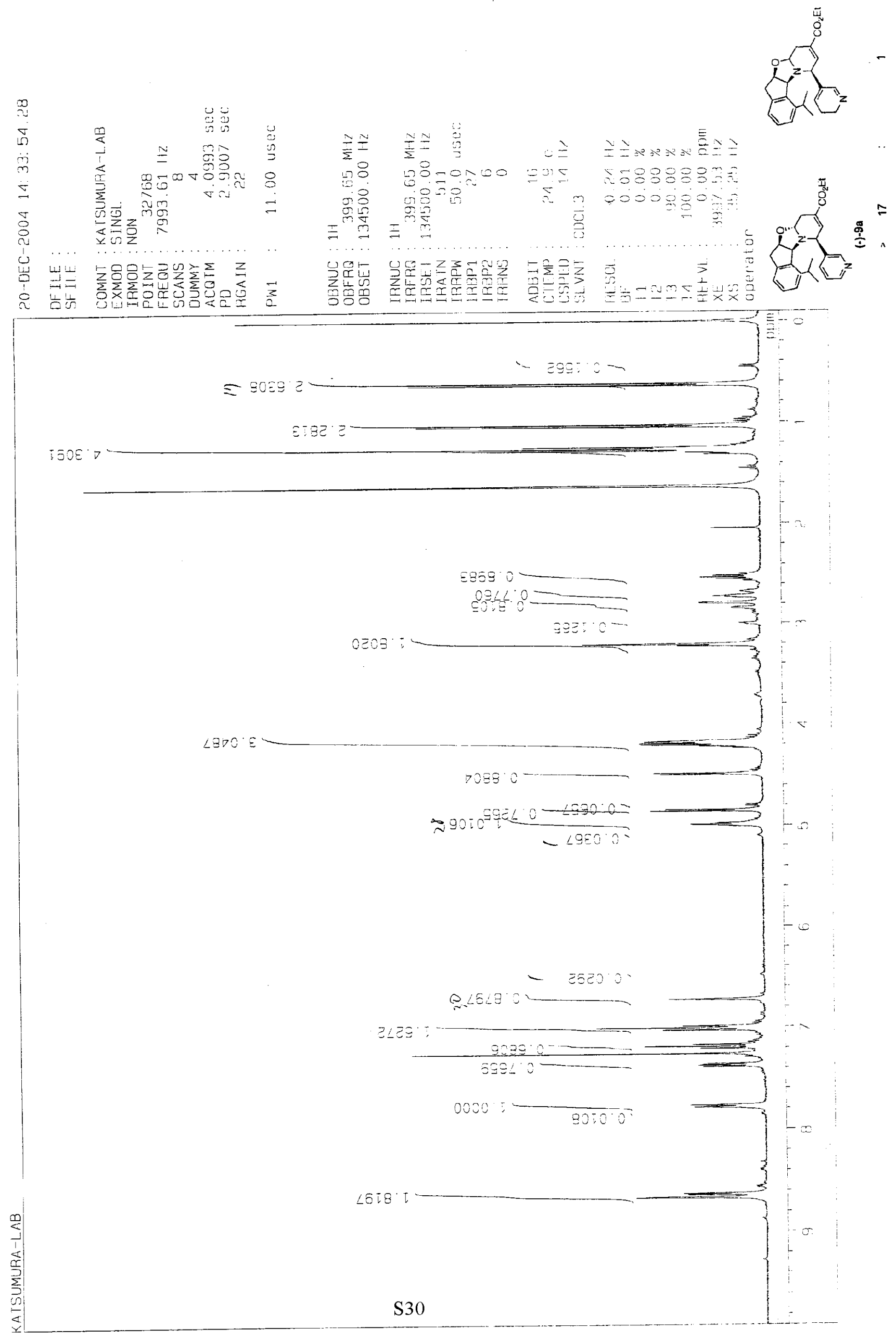



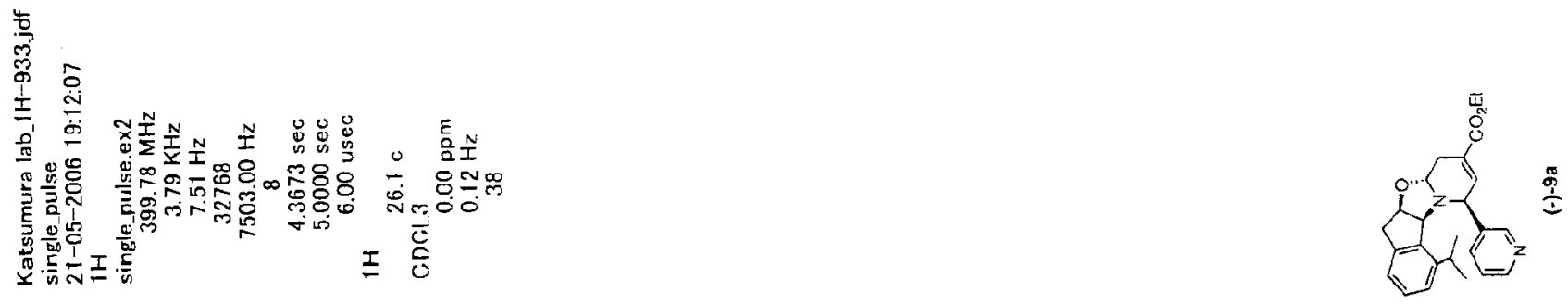

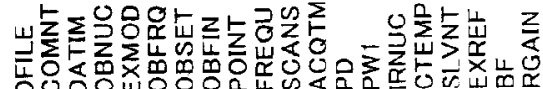

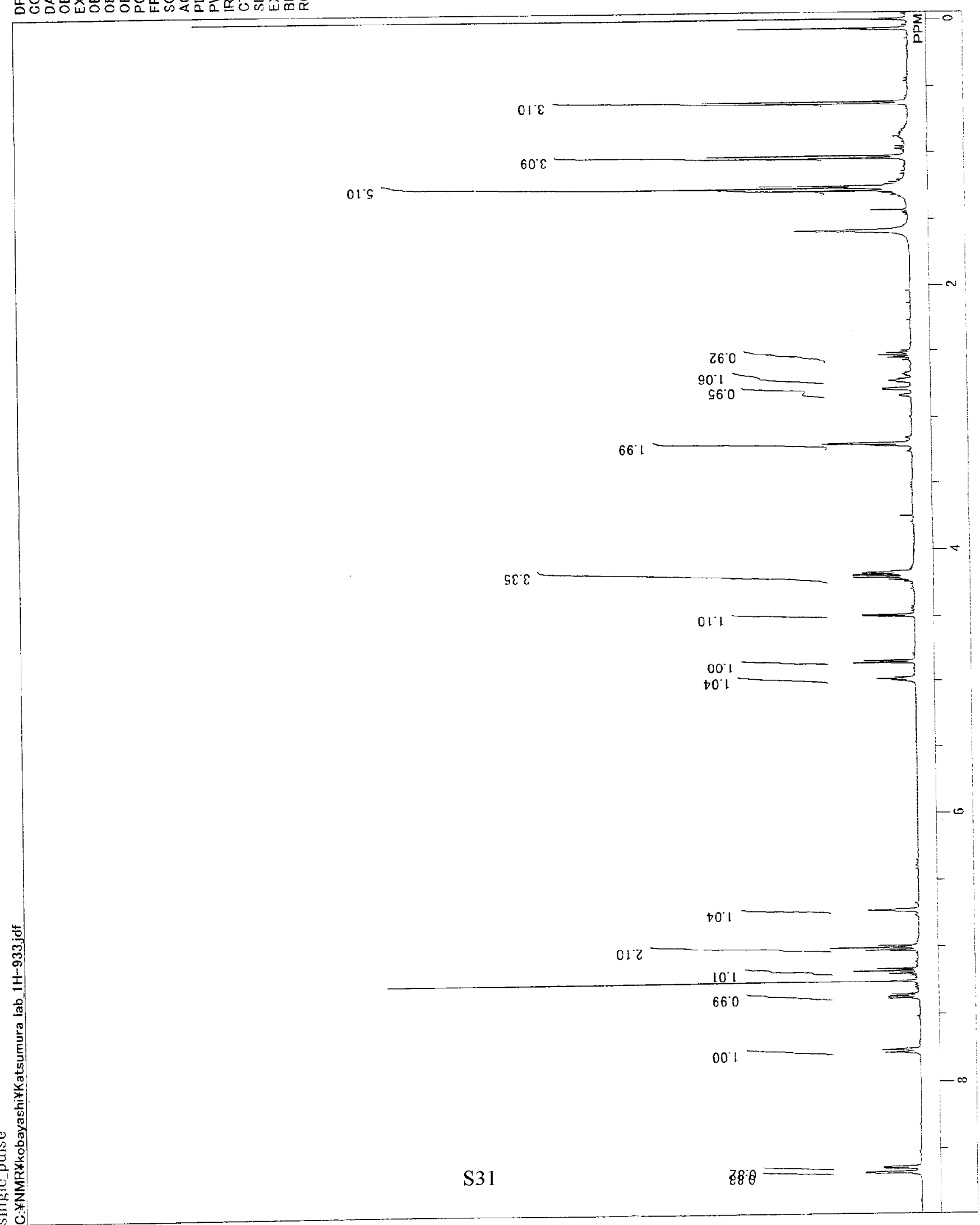


节

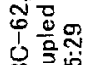

药

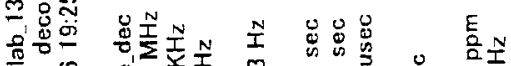

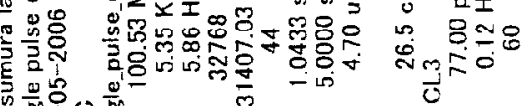

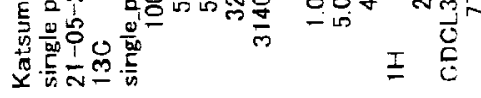

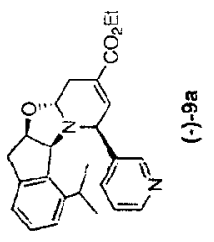

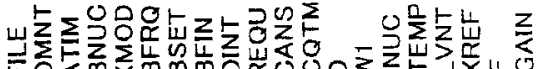

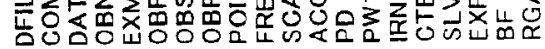

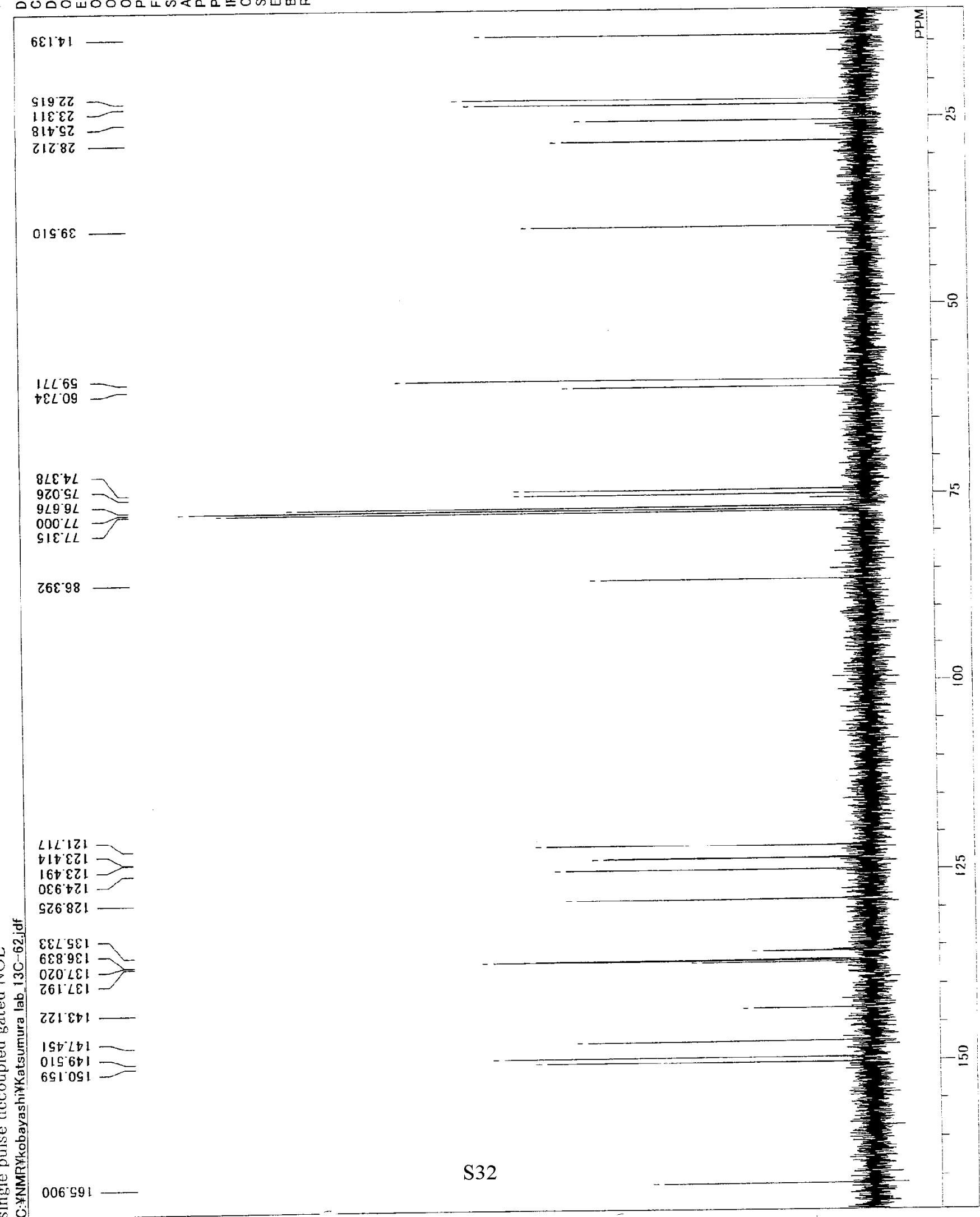




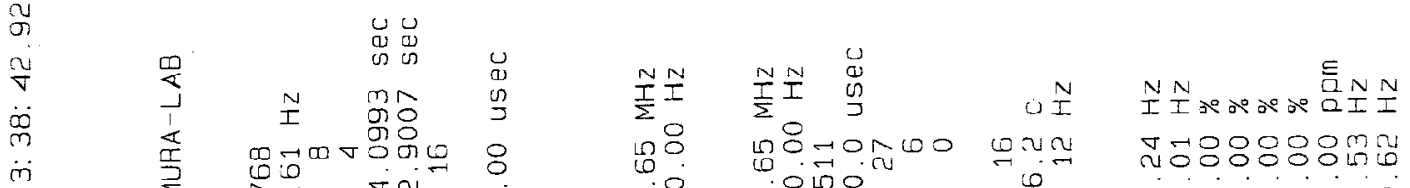

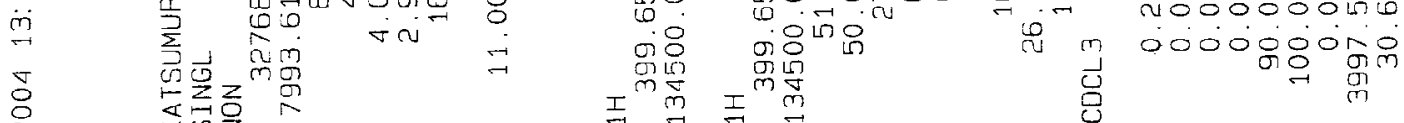

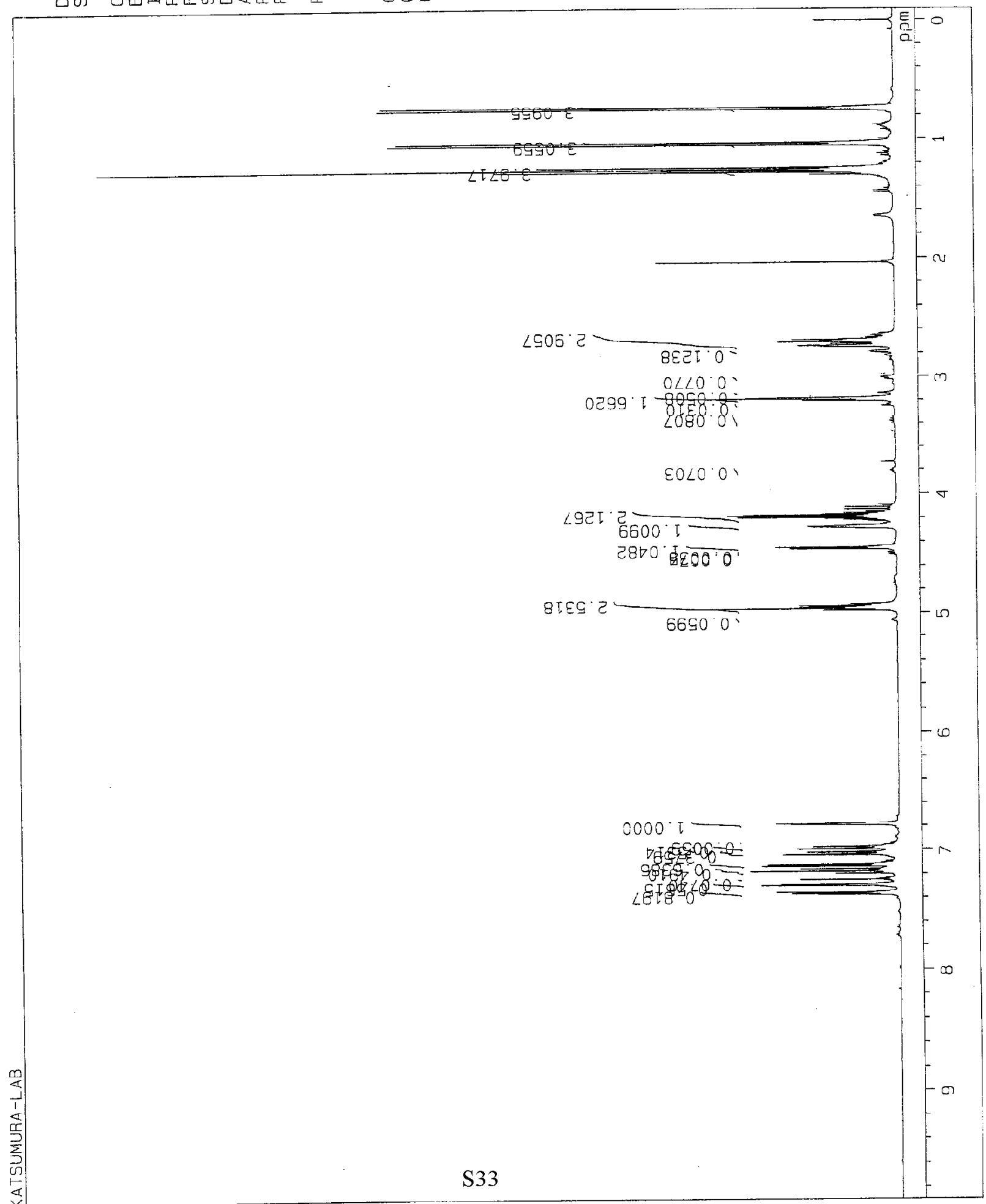



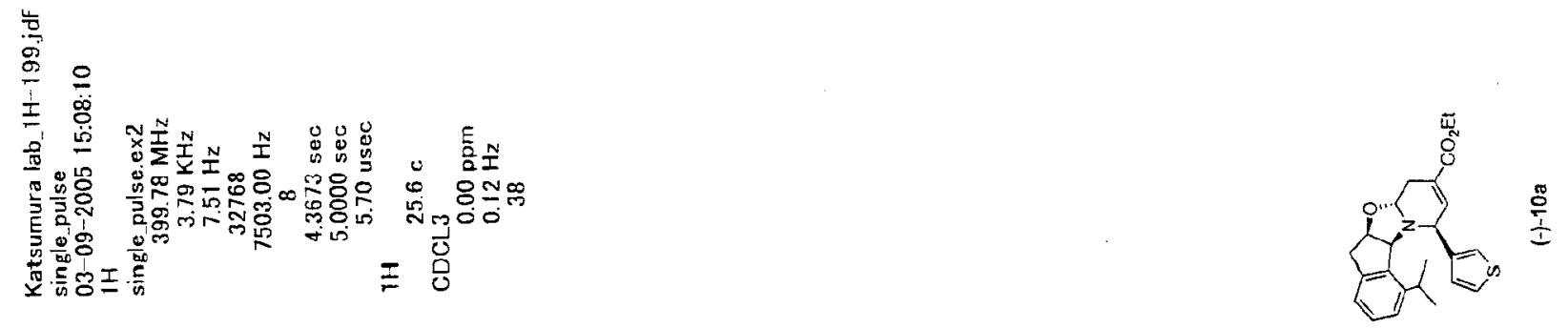

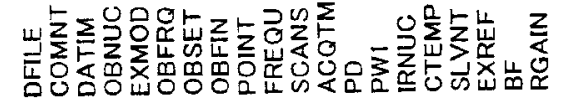

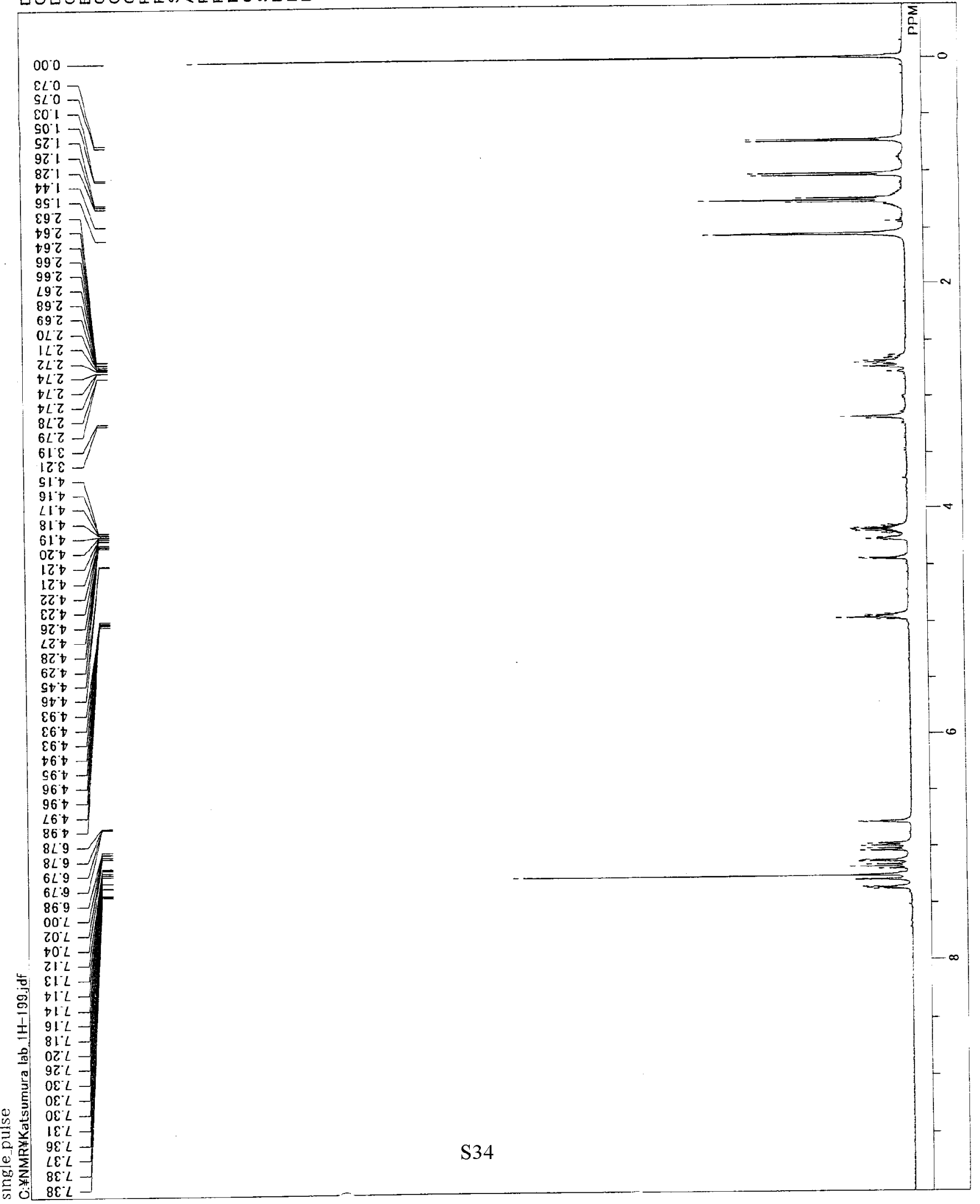


象要

$5, \frac{10}{10}$

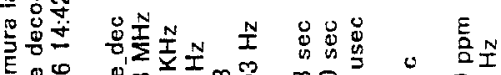

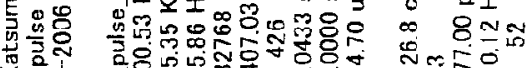

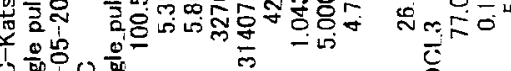

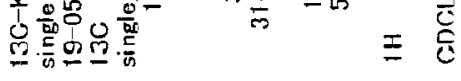

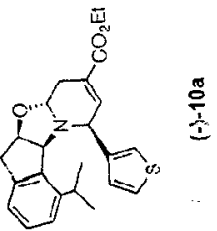

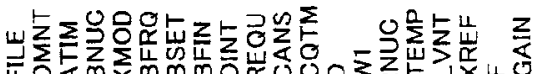

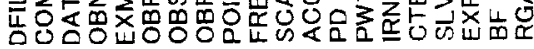

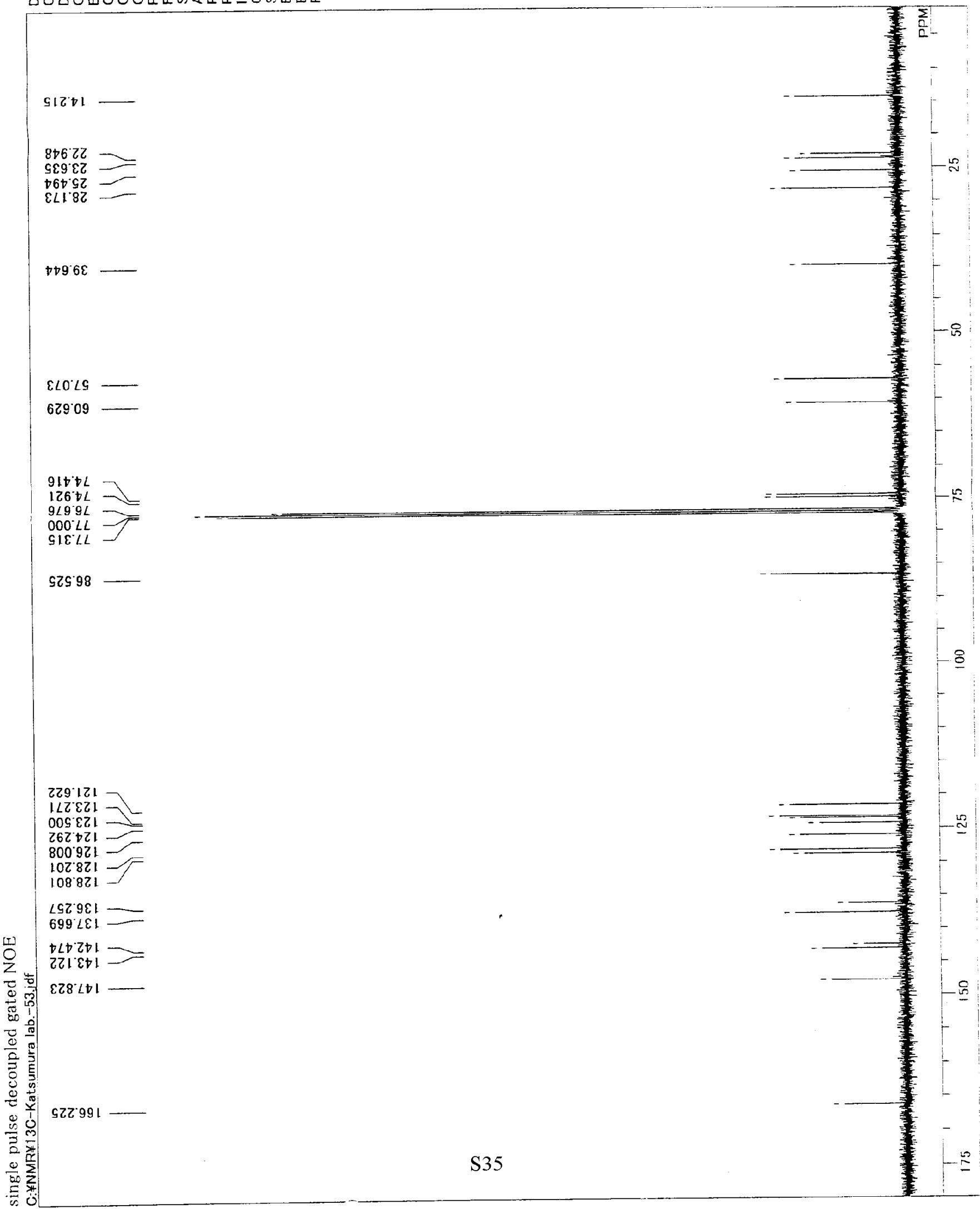




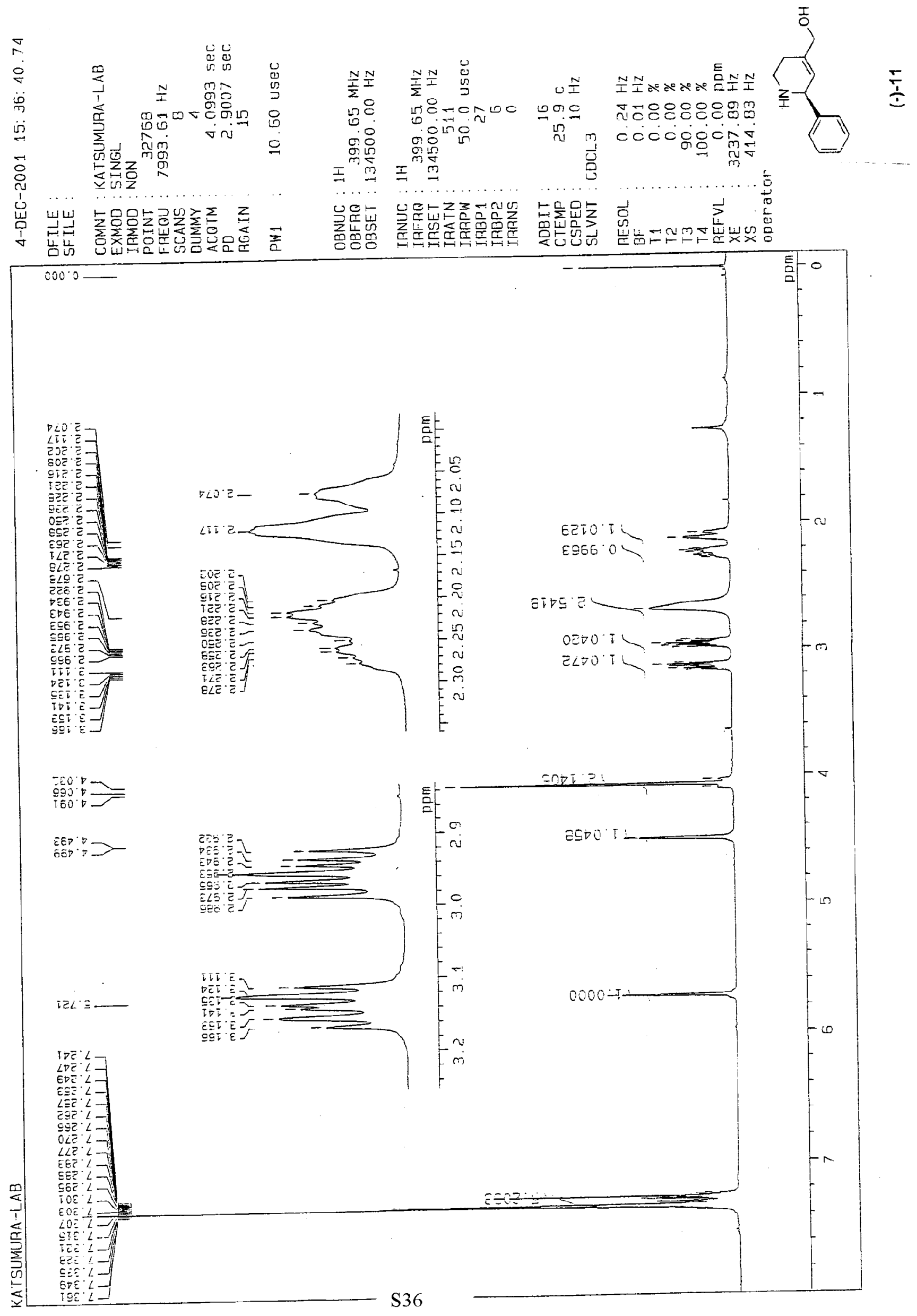




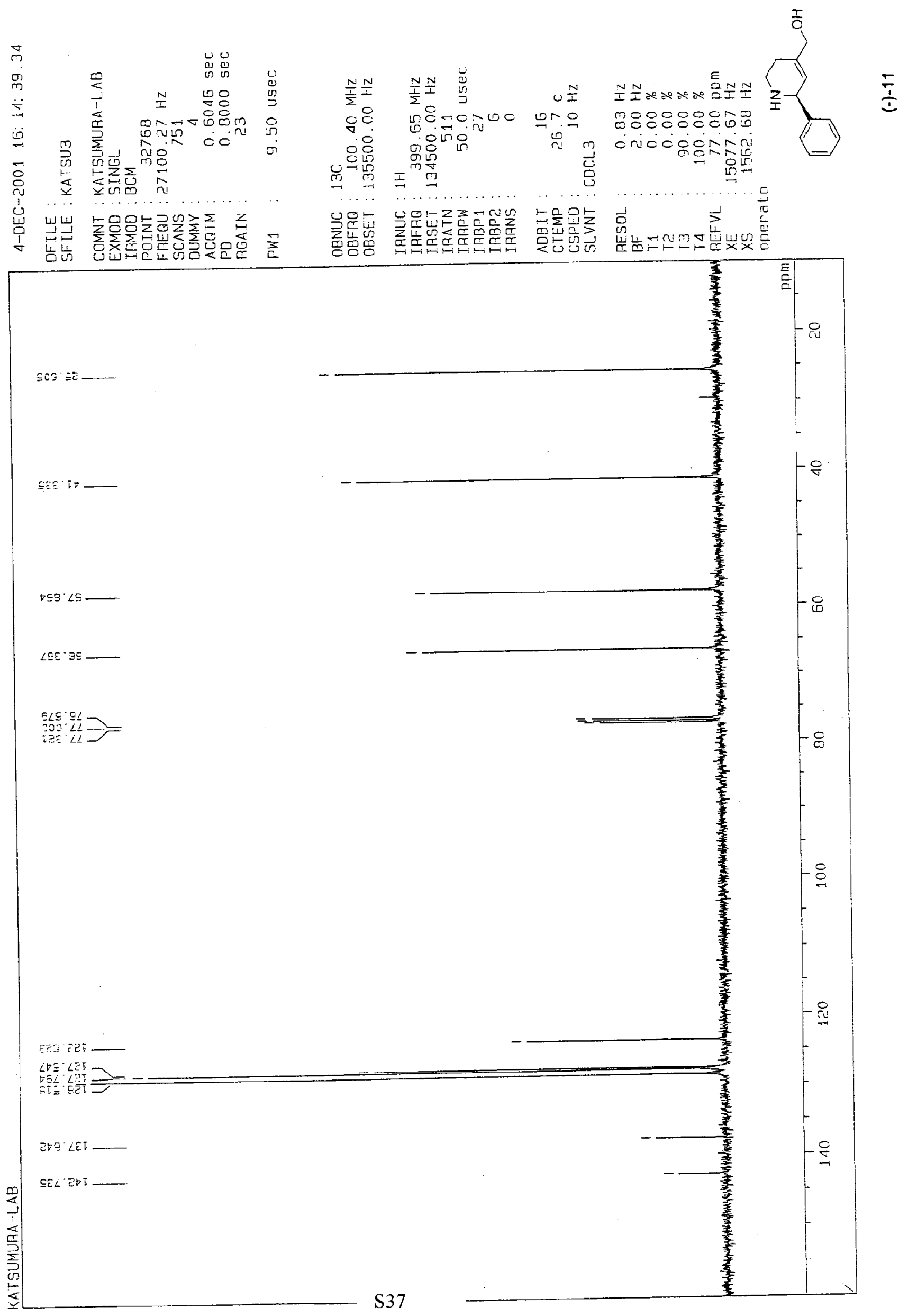




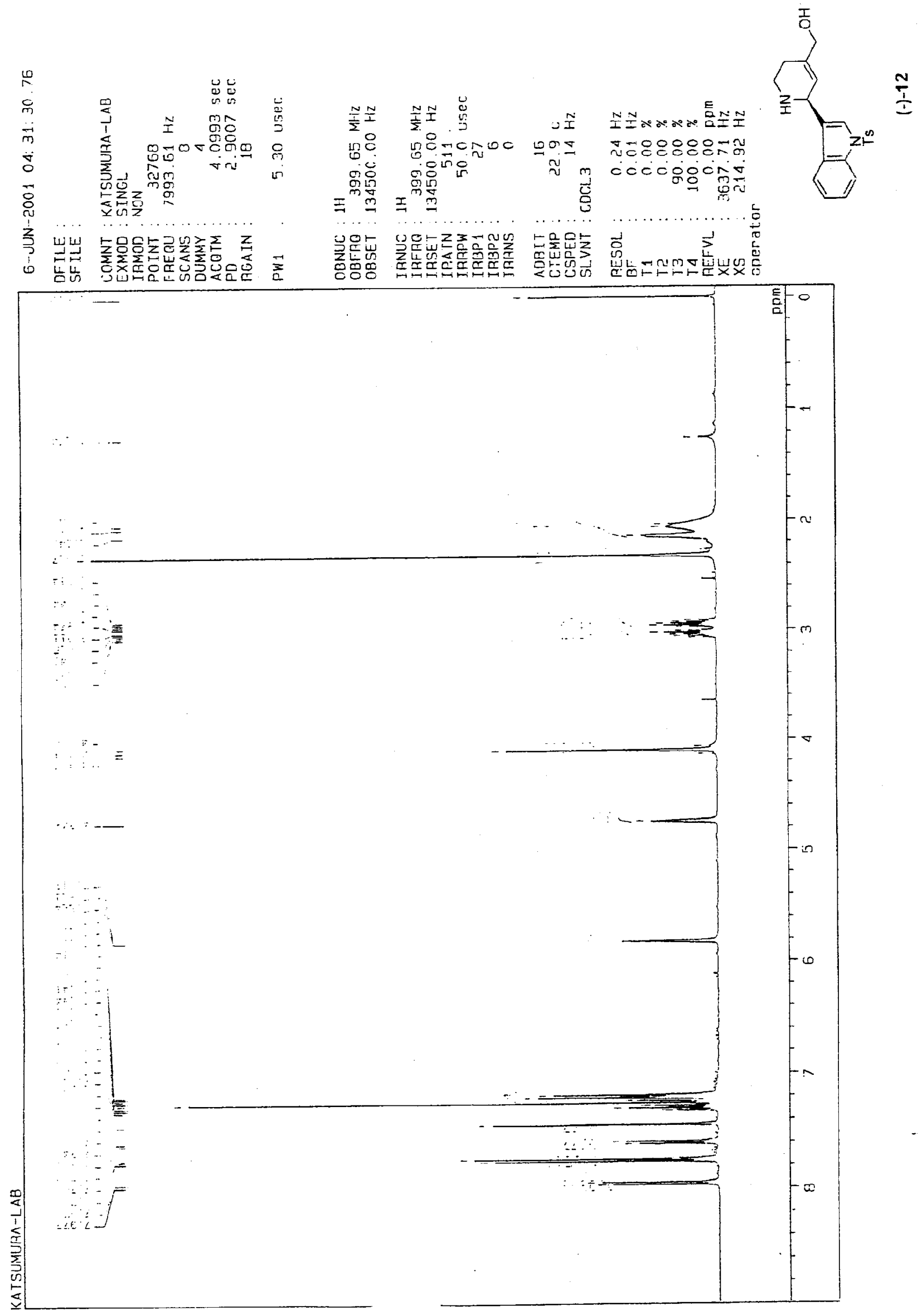


का की

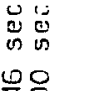

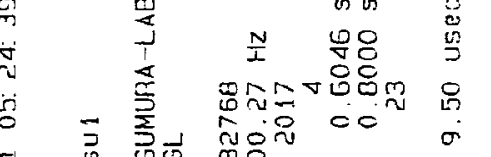

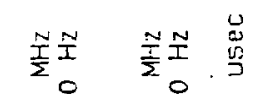

U.

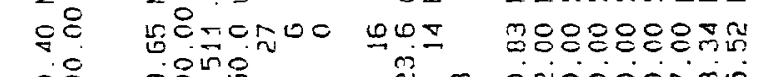

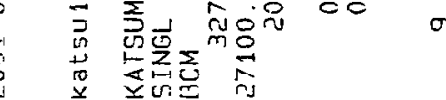

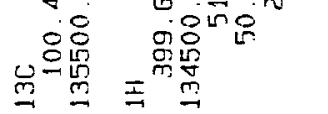

$\stackrel{3}{\tilde{U}}$

oncigoning

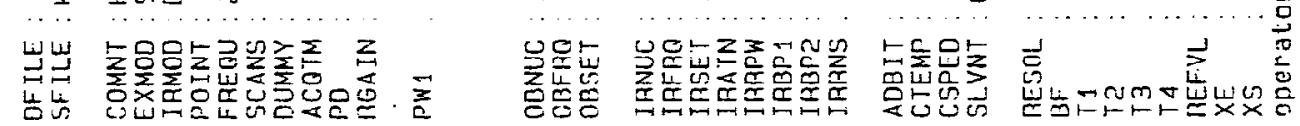

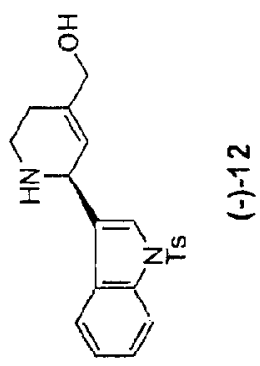

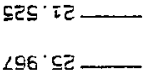

i.9. Ot

$E \angle S \cdot E$

66899

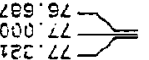
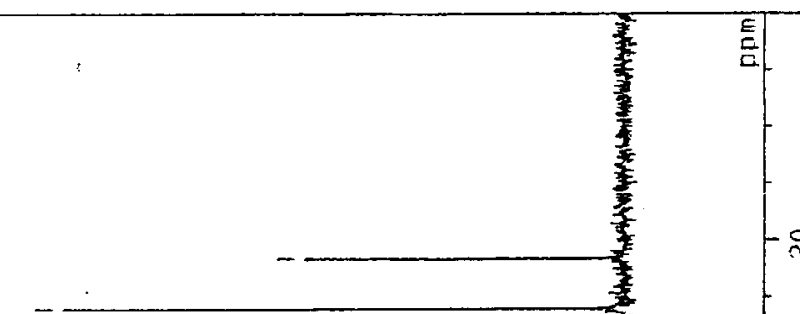

DEL ETI -

558.6II

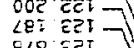

$0<0.051$
$8<2$

$960.5 \mathrm{ct}=$

$20 \mathrm{~g}$ Ge

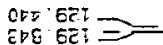

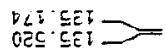

QLEE EEt

$\stackrel{\Upsilon}{<}$

LOE DET

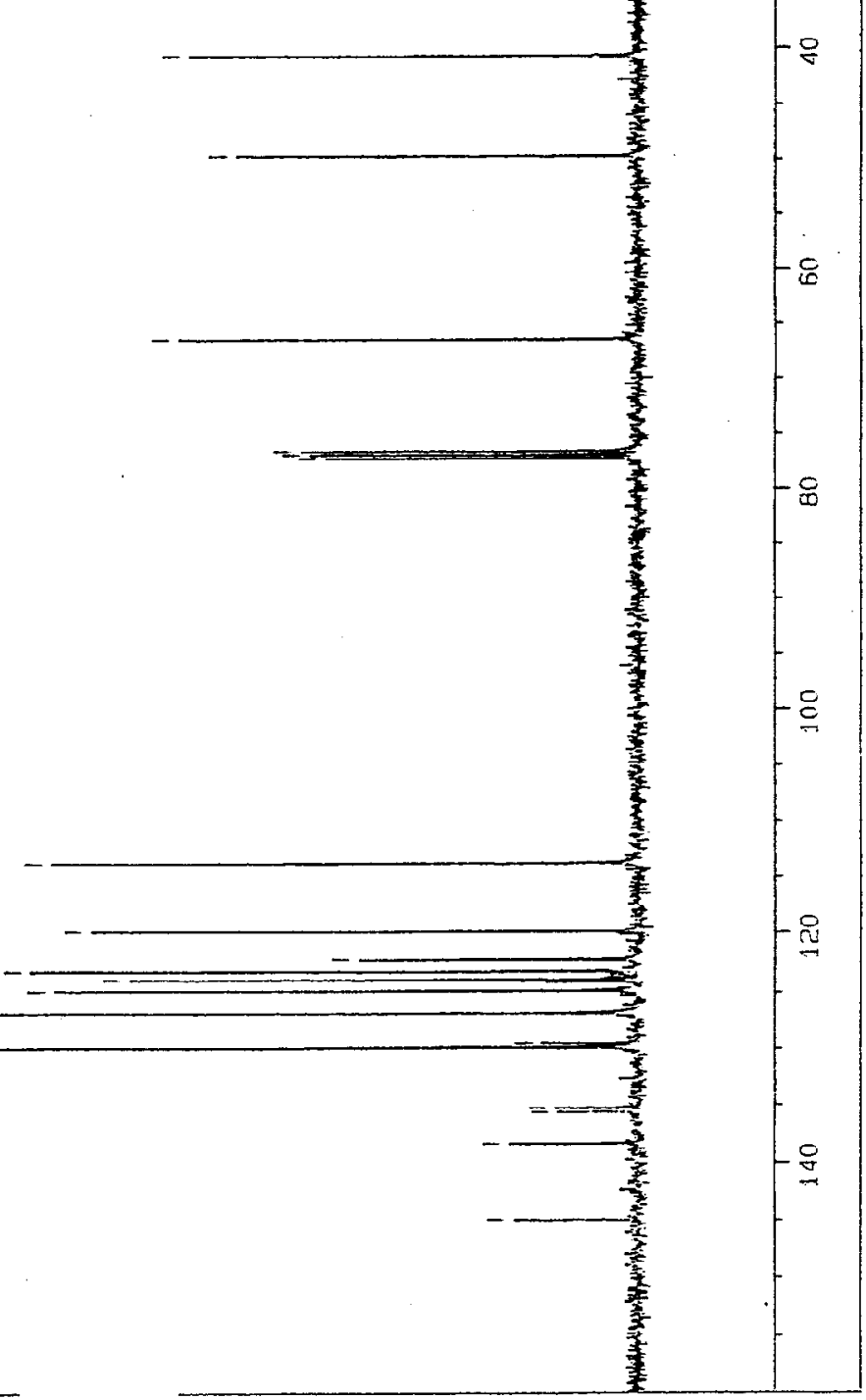




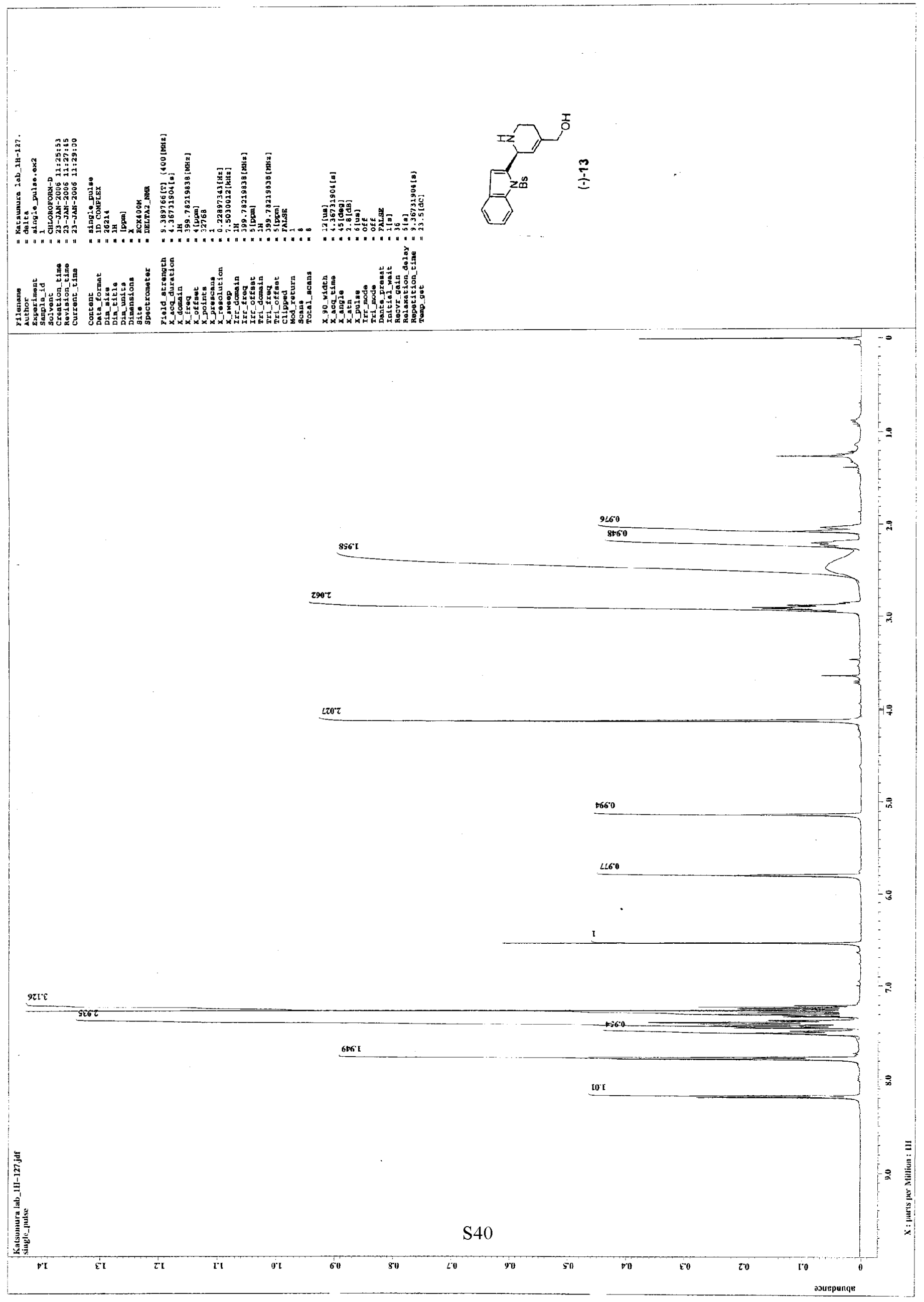



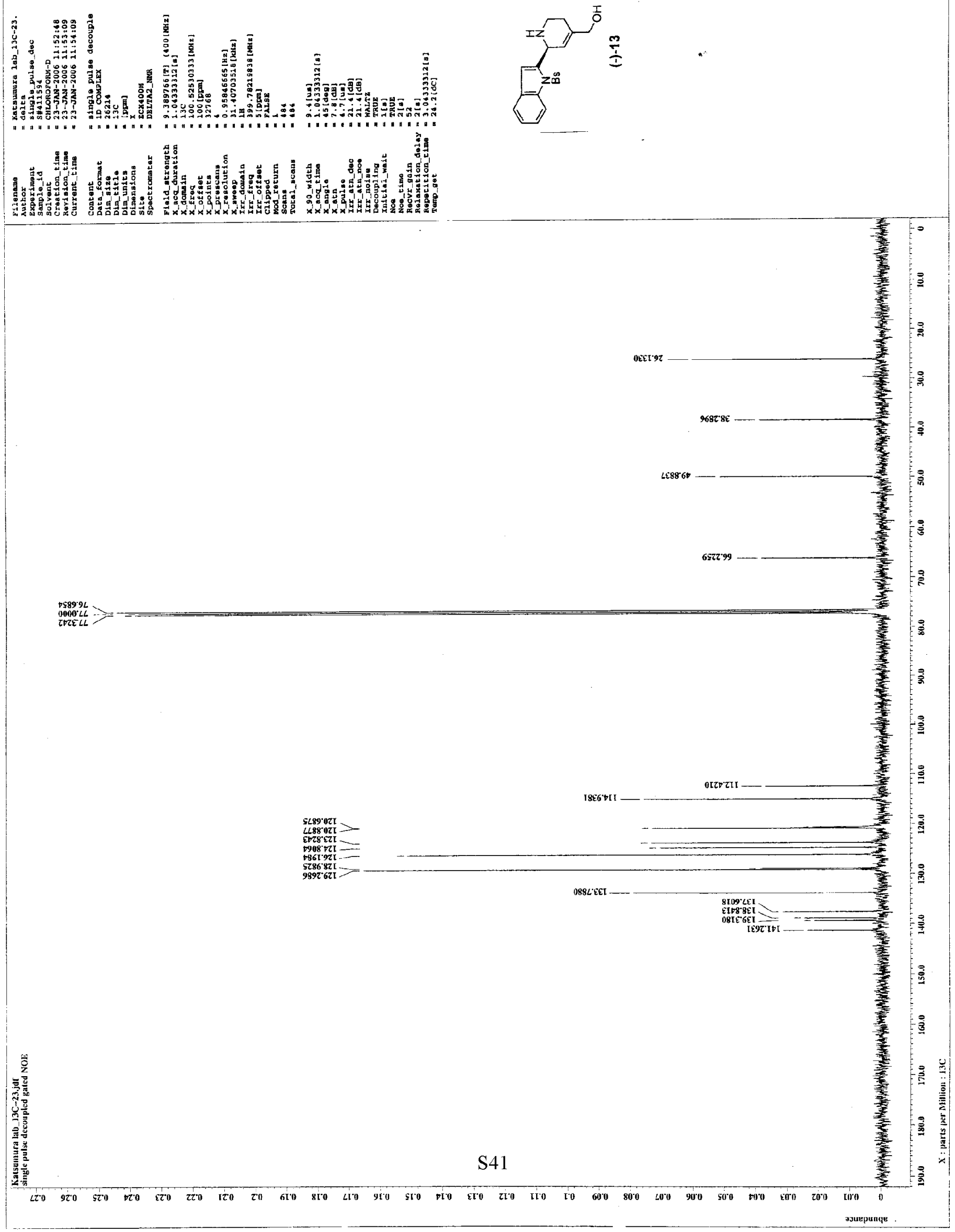

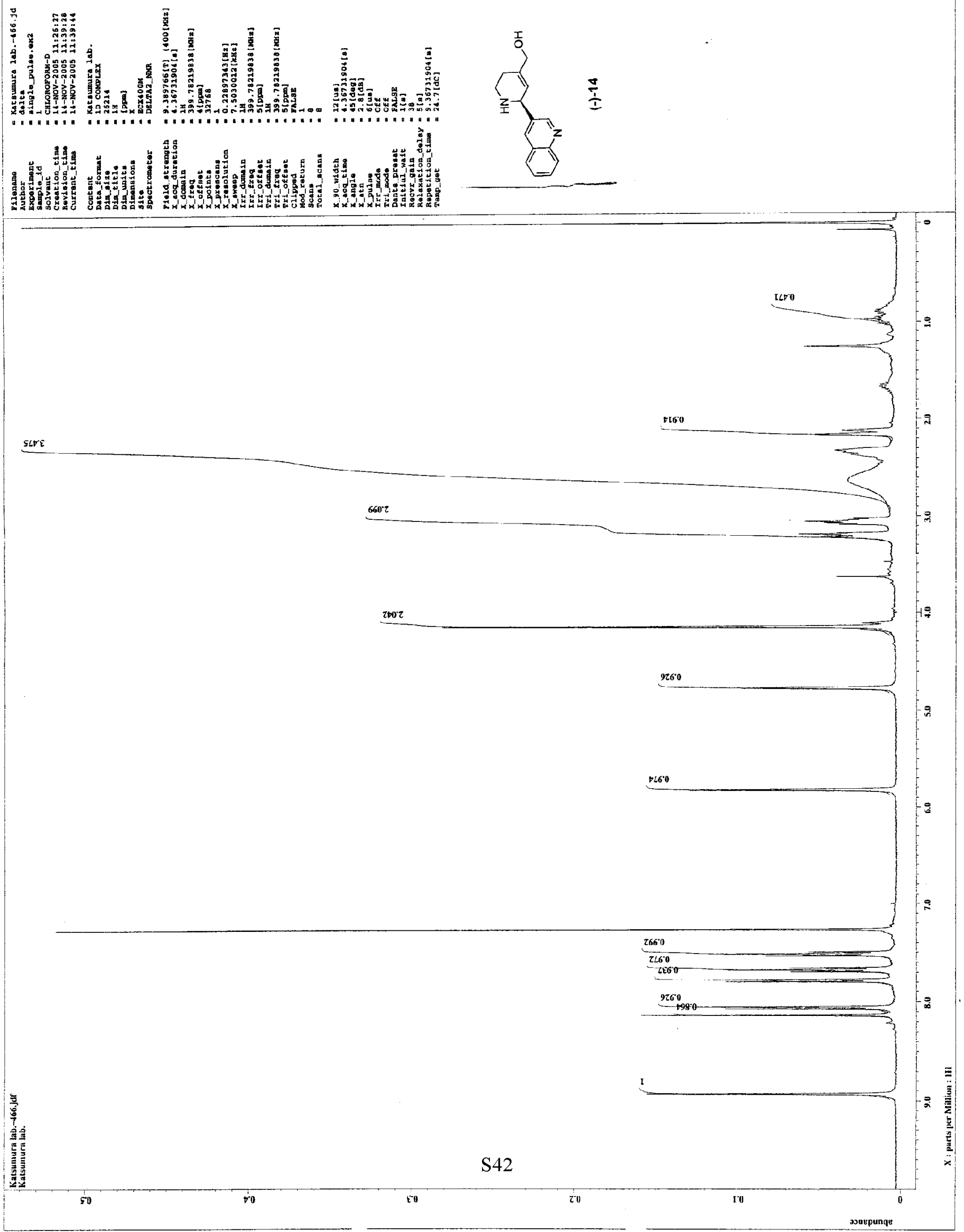

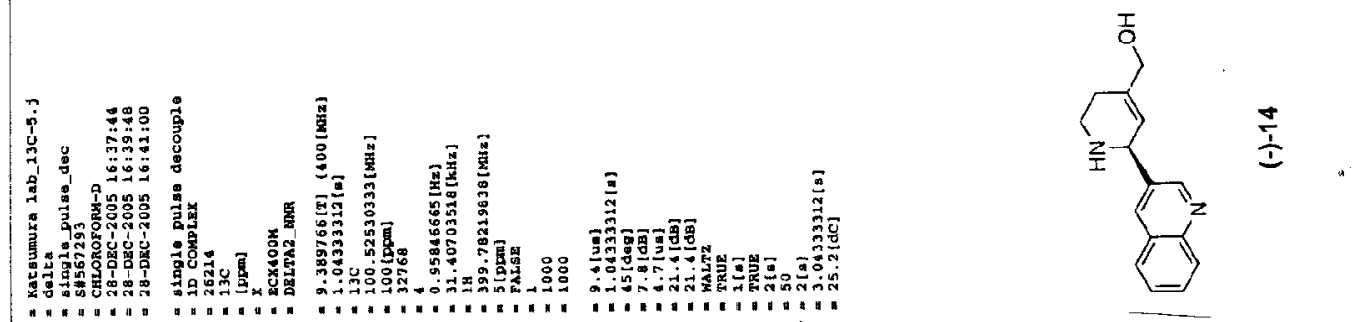

\section{等

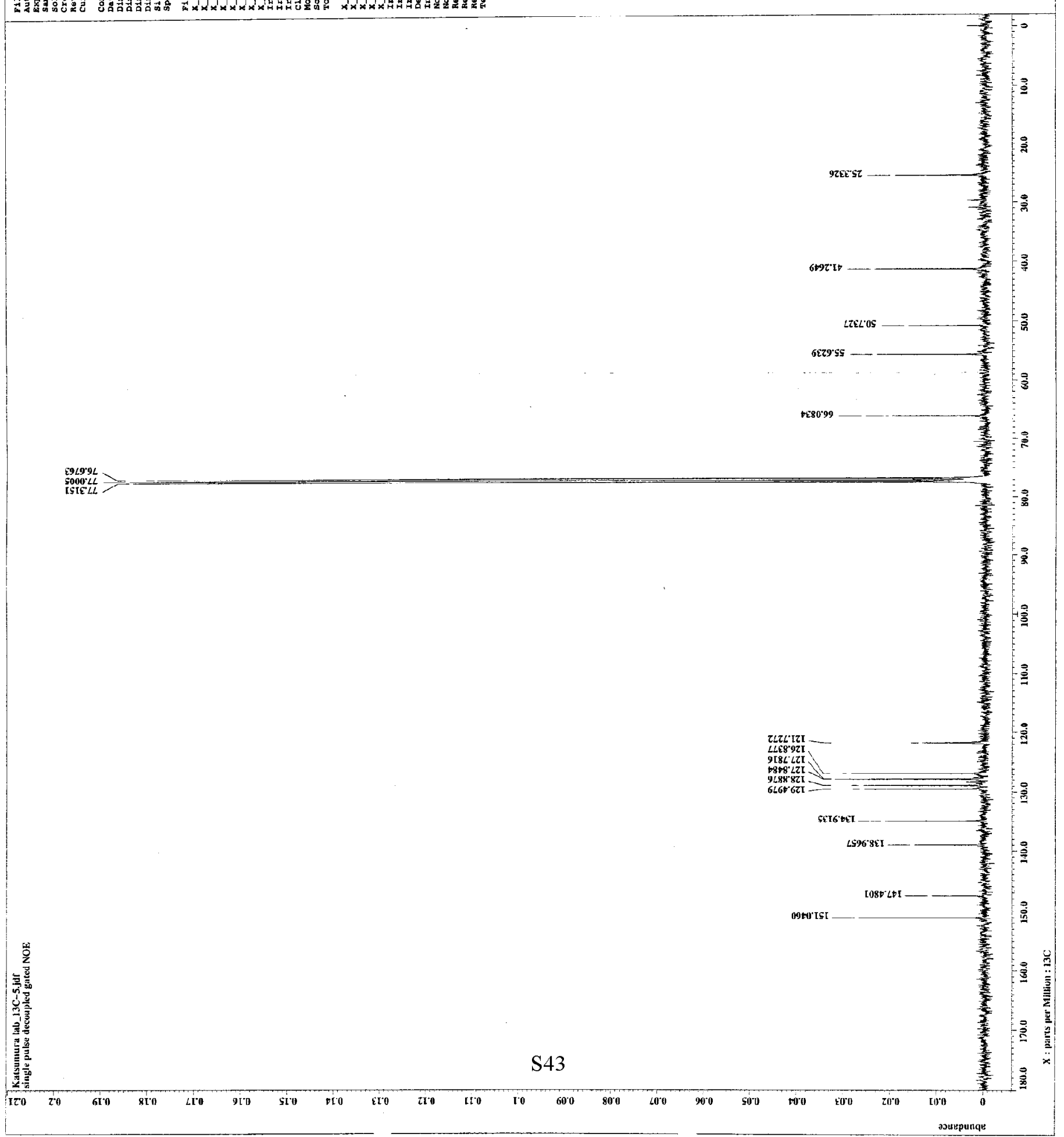




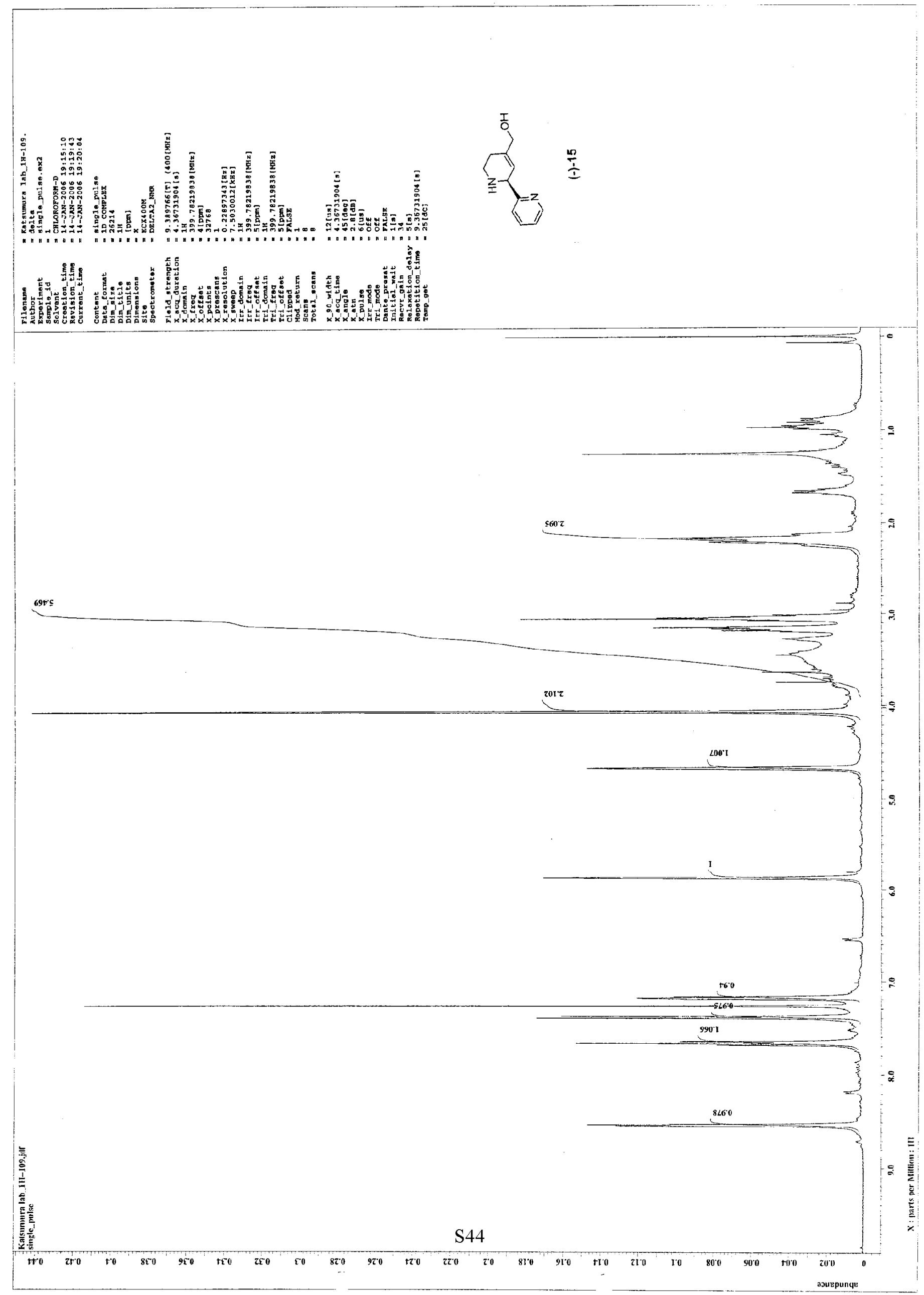



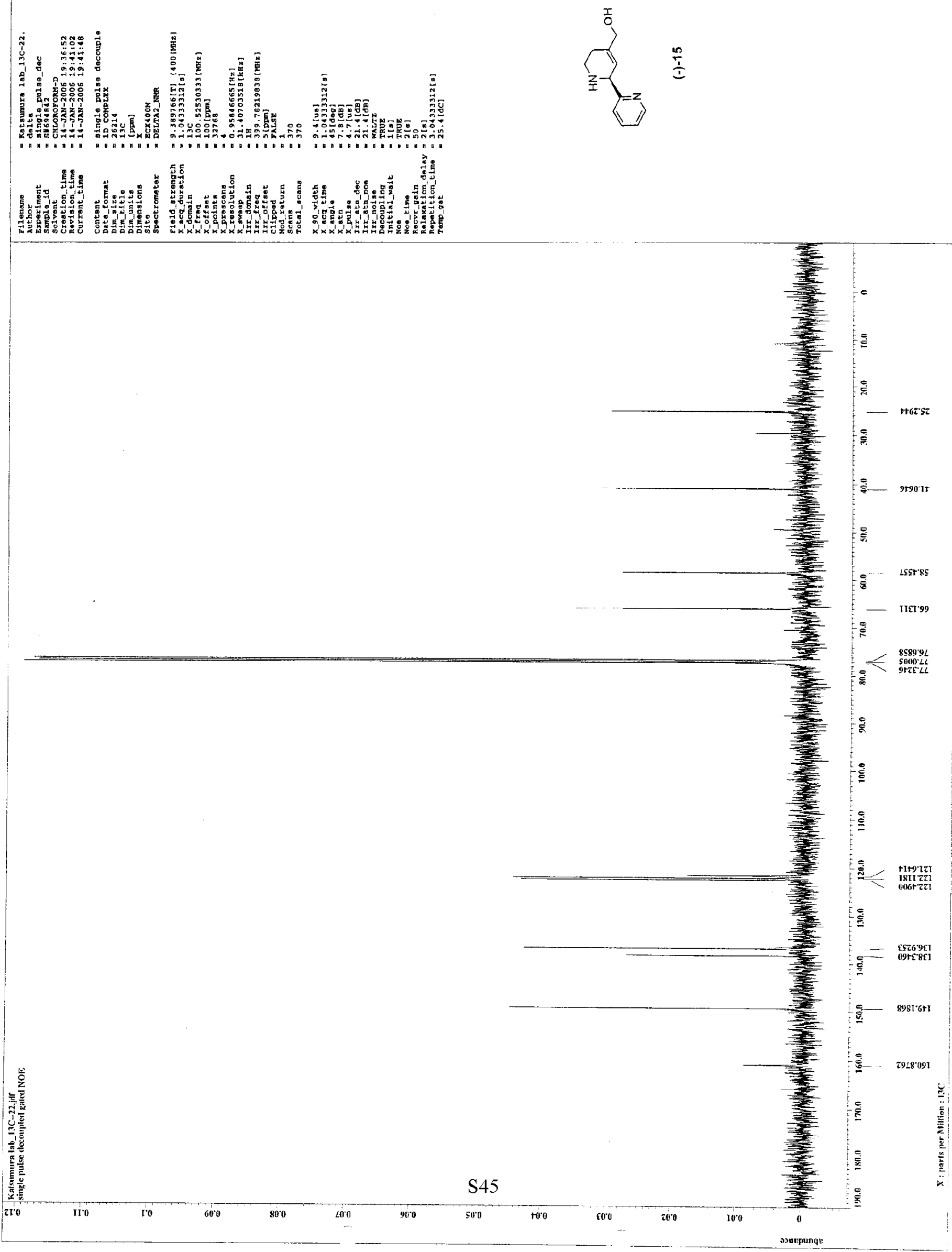


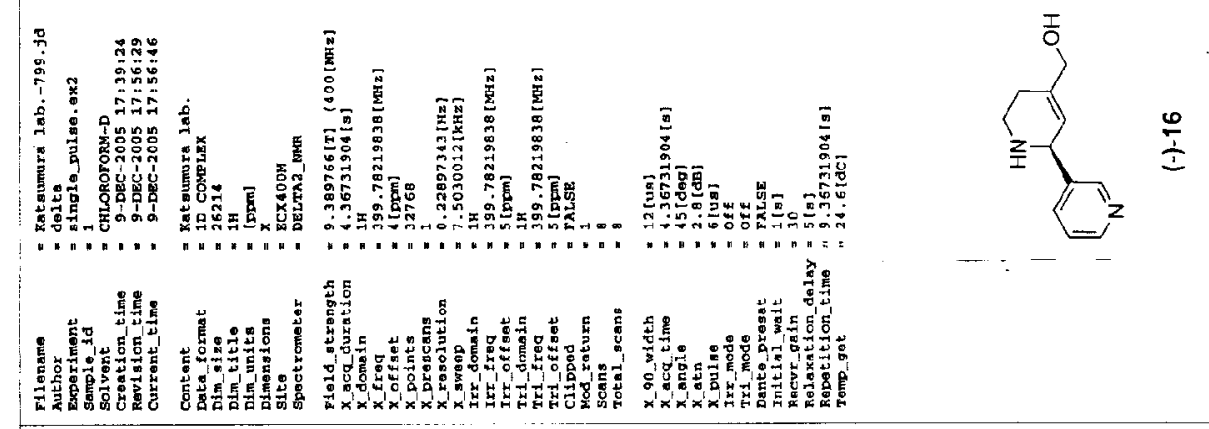

sto't

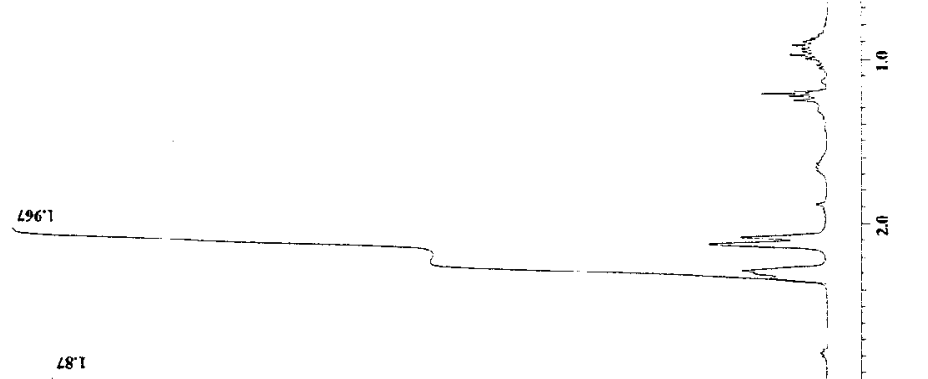

L8:

96

495

8*0

S46

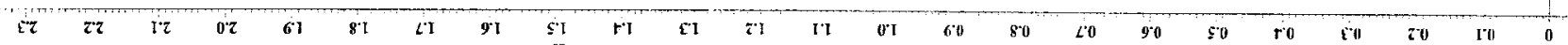


䨐

$\infty \frac{1}{0}$

ํํㅇำ

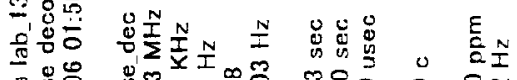

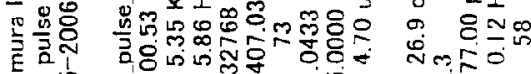

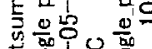

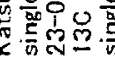

I

$\sum_{2=1}^{\frac{1}{0}} \frac{0}{\frac{1}{3}}$

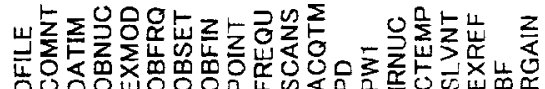

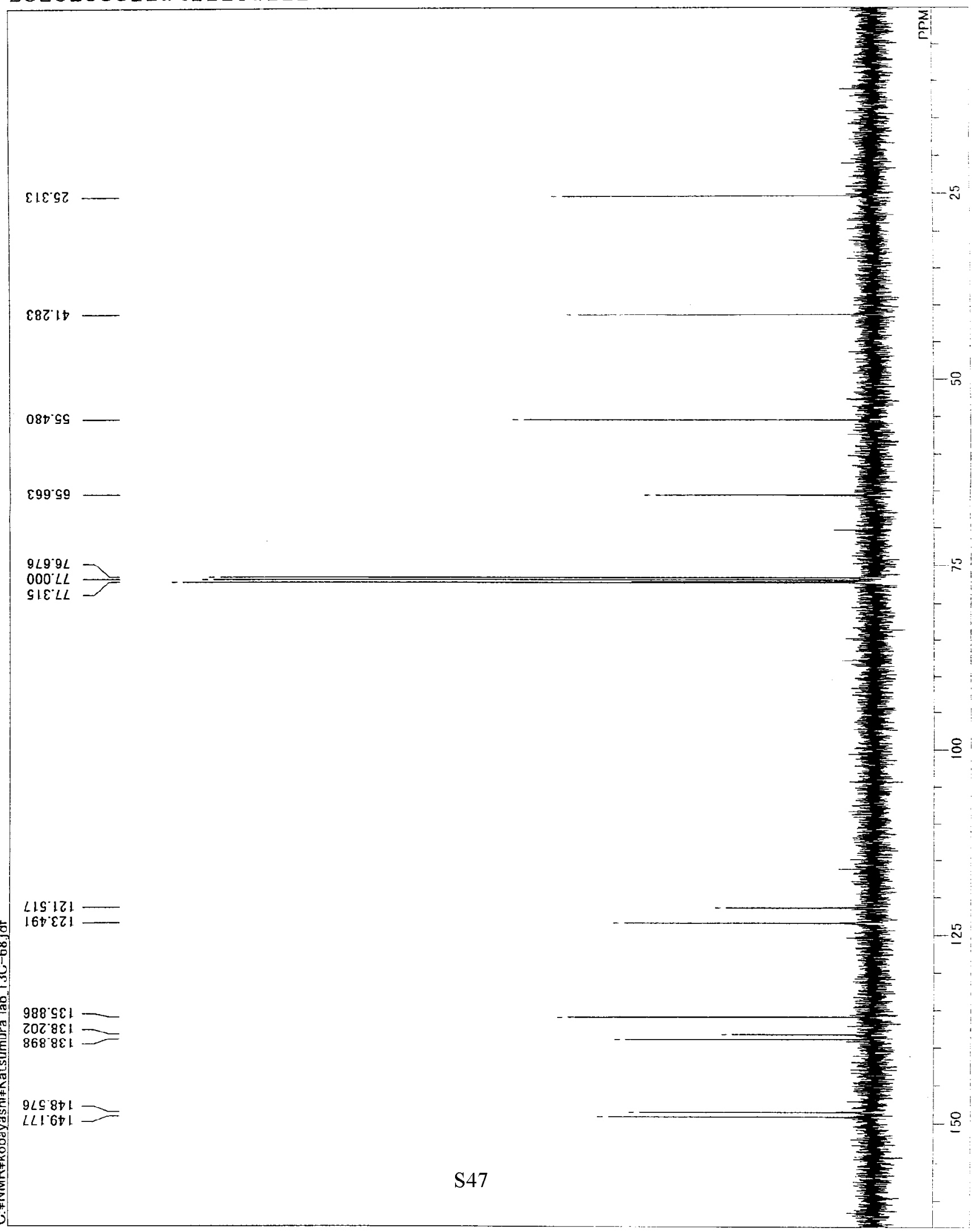




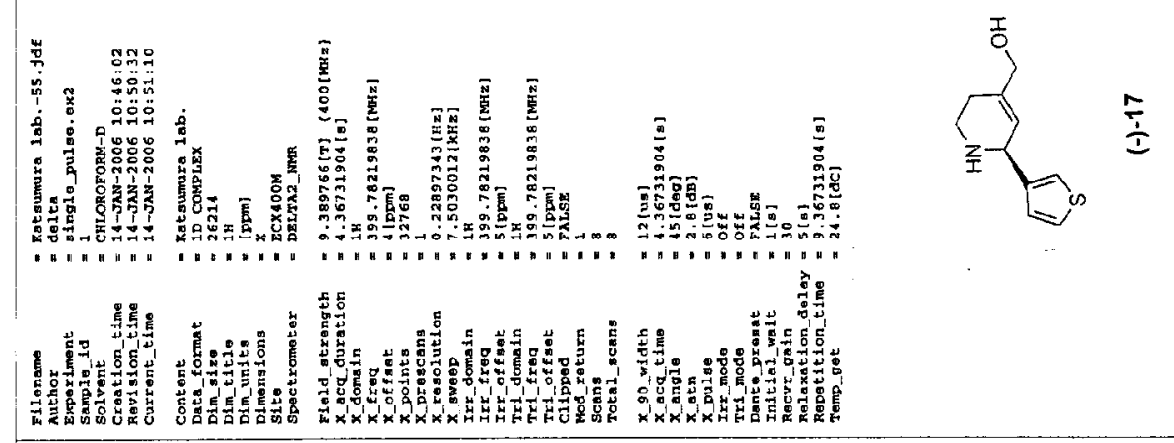

$920 \%$

iII

[961

เง T

6007

IEt) $\stackrel{+60}{+}$ 


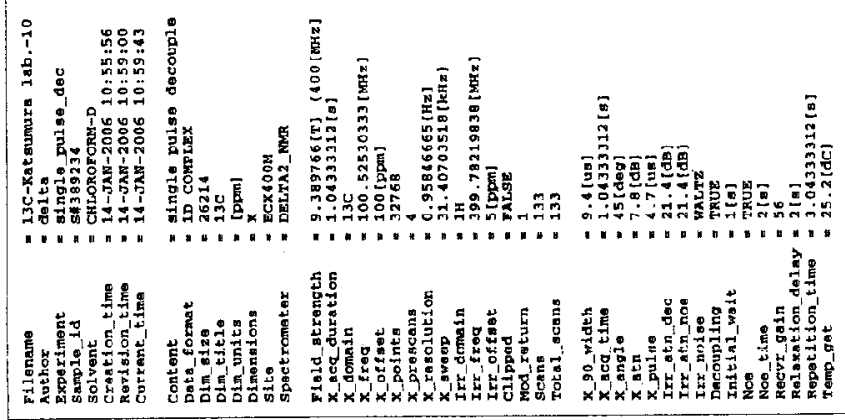

$\sum_{\infty}^{I}$

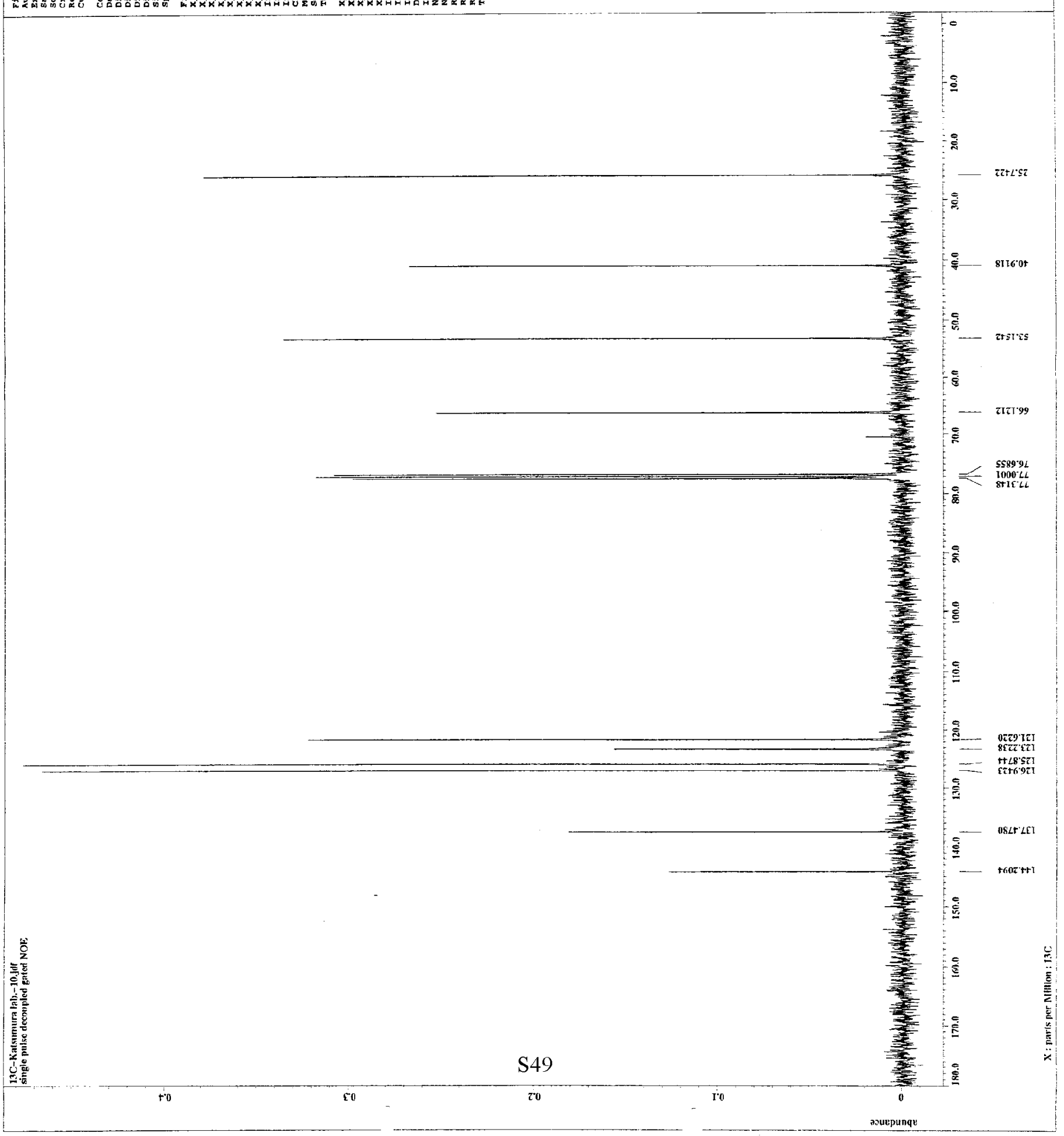

